\title{
Cyclical Budgetary Policy and Economic Growth: What Do We Learn From OECD Panel Data?
}

\section{Citation}

Aghion, Philippe, and loana Marinescu. 2007. Cyclical budgetary policy and economic growth: What do we learn from OECD panel data? In NBER Macroeconomics Annual, ed. Daron Acemoglu, Kenneth Rogoff, and Michael Woodford, 251-278. Chicago: University of Chicago Press

\section{Published Version}

http://www.nber.org/books/acem07-1

\section{Permanent link}

http://nrs.harvard.edu/urn-3:HUL.InstRepos:3350066

\section{Terms of Use}

This article was downloaded from Harvard University's DASH repository, and is made available under the terms and conditions applicable to Other Posted Material, as set forth at http:// nrs.harvard.edu/urn-3:HUL.InstRepos:dash.current.terms-of-use\#LAA

\section{Share Your Story}

The Harvard community has made this article openly available.

Please share how this access benefits you. Submit a story.

\section{Accessibility}




\title{
Cyclical Budgetary Policy and Economic Growth: What Do We Learn from OECD Panel Data?*
}

\author{
Philippe Aghion ${ }^{\dagger}$ and Ioana Marinescu ${ }^{\ddagger}$
}

June 7, 2006

\begin{abstract}
This paper uses yearly panel data on OECD countries to analyze the relationship between growth and the cyclicality of government debt. We develop new time-varying estimates of the cyclicality of public debt. Our main findings can be summarized as follows: (i) less procyclical public debt growth can have significantly positive effects on productivity growth, in particular when financial development is lower; (ii) public debt growth has become increasingly countercyclical in most OECD countries over the past twenty years, but this trend has been less pronounced in the EMU; (iii) less financially developed or more open economies display less countercyclical public debt growth.
\end{abstract}

\section{Introduction}

A common view among macroeconomists, is that there exists a perfect dichotomy between macroeconomic policy (budget deficit, taxation, money supply) which should affect primarily the short-run, and long-run economic growth which, if anything, should depend only upon structural characteristics of the economy (property right enforcement, market structure, market mobility and so forth). That macroeconomic policy should not be a key source of growth, is further hinted at by recent contributions such as Acemoglu et al (2004) and Easterly (2005), which argue that the correlation between macroeconomic volatility and growth (Acemoglu et al) or those between growth and macroeconomic variables (Easterly), become insignificant once one controls for institutions.

\footnotetext{
*This work owes a lot to Robert Barro who contributed abundant comments and advice and in particular the theory section underlying the first-stage analysis. We were inspired by many fruitful conversations with Philippe Bacchetta, Laurence Bloch, Elie Cohen, Enisse Kharroubi, Jean Pisani-Ferry, Romain Ranciere, Ken Rogoff, and with members of the Sapir group. The authors thank Philippe Moutot for very helpful comments on an earlier draft and Ann Helfman, Julian Kolev and Anne-Laure Piganeau for outstanding research assistance. Finally, we are highly indebted to Konrad Kording for his collaboration on the first stage analysis section and more specifically for helping us implement the MCMC methodology.

${ }^{\dagger}$ Harvard University and NBER

${ }^{\ddagger}$ Harvard University and London School of Economics
} 
In this paper we question that view by showing that, the cyclicality of public debt growth is significantly correlated with GDP growth, with more a countercyclical public debt policy being more growth-enhancing the lower the country's level of financial development. These results hold in a sample of OECD countries with comparable institutional environments.

Our contribution in this paper is three-fold. It is first to compute and analyze the cyclicality of government debt on a panel of OECD countries, that is, how government debt responds to fluctuations in the output gap over time. Second, it is to use these yearly panel data to assess the importance for growth of moving towards more countercyclical budgetary policies at various levels of financial development. Third, it is to investigate some determinants of the procyclicality of public debt. Our main findings can be summarized as follows: (i) public debt growth has become increasingly countercyclical in most OECD countries over the past twenty years, but this trend has been significantly less pronounced in the EMU; (ii) less procyclical public debt growth can have significantly positive effects on growth when financial development is lower; in particular our estimates suggest that the eurozone could increase its annual growth rate by 0.15 percentage points per year by making its public debt growth become as countercyclical as that in the US; (iii) less financially developed or more open economies display less countercyclical government debt growth.

The idea that cyclical macroeconomic policy should affect productivity growth, is more in line with the Schumpeterian view of business cycles and growth, whereby recessions provide a cleansing mechanism for correcting organizational inefficiencies and for encouraging firms to reorganize, innovate or reallocate to new markets. The cleansing effect of recessions is also to eliminate those firms that are unable to reorganize or innovate. Now, if firms could always borrow enough funds to either reorganize their activities or move to new activities and markets, and the same was true for workers trying to relocate from one job to another, the best would be to recommend that governments do not intervene over the business cycle, and instead let markets operate.

However, suppose that the borrowing capacity of firms is proportional to their current earnings (the factor of proportionality is what we refer to as the credit multiplier, with a higher multiplier reflecting a higher degree of financial development in the economy). In a recession, current earnings are reduced, and therefore so is the firms' ability to borrow in order to make new innovative investments or simply maintain previous innovation programs in the face of idiosyncratic liquidity shocks. This, in turn suggests that a countercyclical budgetary policy may foster innovation and growth by reducing the negative consequences of a recession (or a bad aggregate shock) on firms' innovative investments. For example, the government may decide to increase the volume of its public investments or that of public consumption, thereby fostering the demand for private firms' products. Or the government may choose to directly increase its subsidies to private enterprises, thereby increasing their liquidity holdings and thus making it easier for them to face idiosyncratic liquidity shocks without having to sacrifice R\&D or other types of longer-term growth-enhancing investments. A natural implication of the above argument is that the lower the level of 
financial development, that is, the tighter the credit constraints faced by firms, the more growth-enhancing such countercyclical policies should be, a conclusion at odds with the dichotomous view that prevails among macroeconomists.

While we do not know of any previous attempt at analyzing the growth effects of countercyclical budgetary policies, analyses of the determinants of the cyclicality of budgetary policies already exist in the literature. For example, Alesina and Tabellini (2005) argue that more corrupt democracies will tend to run more procyclical fiscal policy. The idea is that, in good times, voters demand that the government cut taxes or provide more public services instead of reducing debt, because they cannot observe the debt reduction and can suspect the government of appropriating the rents associated with good economic conditions. In equilibrium, this leads to a more procyclical policy as the moral hazard problem worsens, in the sense that governments are more likely to divert public resources in booms. They also show that this mechanism tends to be more powerful in explaining the variation observed in the data than borrowing constraints alone. While Alesina and Tabellini (2005) are using a large sample of countries and explore cross-section variations, in this study we use panel analysis on OECD countries. This makes the use of corruption indices impractical for two reasons. First, there is almost no cross-sectional variation in corruption indices within the OECD. Second, there is even less variation of these indices across time for individual countries.

In a similar vein, Calderon et al. (2004) show that emerging market economies with better institutions are more able to conduct a countercyclical fiscal policy $^{1}$. Their empirical analysis is based on the International Country Risk Guide. Although the variation in this indicator is limited across OECD countries and time, it presents somewhat more variation than corruption indexes ${ }^{2}$.

Other papers such as Gali and Perotti (2003) and Lane (2003) focus like we do on OECD countries. Gali and Perotti investigate whether fiscal policy in the European Monetary Union (EMU) has become more procyclical after the Maastricht treaty. They find no evidence for such a development. They do find however that while there is a trend in the OECD towards a more countercyclical fiscal policy over time, the EMU is lagging behind that trend. Lane (2003) is probably the paper that comes closer to the analysis developed in the fourth section of our paper. Lane examines the cyclical behavior of fiscal policy within the OECD. He then uses trade openness, output volatility, output per capita, the size of the public sector and a index for political power dispersion to examine cross-country differences in cyclicality. The reason why

\footnotetext{
${ }^{1}$ There is also the paper by Talvi and Vegh (2000), where it is argued that high output volatility is most likely to generate a procyclical government spending. The idea is that running a budget surplus generates political pressures to spend more: the government therefore minimizes that surplus and becomes pro-cyclical. This movement is then accentuated by a volatile output, and therefore a volatile tax base.

${ }^{2}$ We have also used these indicators in our analysis. However, they typically have no significant effect on GDP growth over time in our sample. Moreover, as they are less widely available than our main variables of interest, their use considerably restricts the available sample, leading to less precise estimates. Finally, we have therefore decided not to use these indicators in the results reported here.
} 
power dispersion may play a role is taken from Lane and Tornell (1998): when multiple political groups compete for public spending, the latter may become more procyclical. Indeed, no group wants to let any substantial fiscal surplus subsist because they are afraid that this will not lead to debt repayment but to other groups appropriating that surplus. Lane finds in particular evidence that GDP growth volatility, trade openness and political divisions lead to a more procyclical spending pattern, even though the effect of political divisions is not present for all categories of spending. We contribute to this literature by using yearly panel data to analyze the cyclicality of budgetary policies and its determinants within OECD countries, and we show that the degree of financial development is an important element to explain both, cross-country and within country variations in such policies, while future or present EMU membership explains cross-country variations.

Most closely related to our second stage analysis of the effect of countercyclical budgetary policy on growth, are Aghion-Angeletos-Banerjee-Manova (2005), henceforth AABM, and Aghion-Bacchetta-Ranciere-Rogoff (2006), henceforth ABRR. AABM develop a model to explain why macroeconomic volatility is more negatively correlated with productivity growth, the lower financial development, and they test this prediction using cross-country panel data. ABRR move from a closed real to an open monetary economy and show that a fixed nominal exchange rate regime or lower real exchange rate volatility are more positively correlated with productivity growth, the lower financial development and the lower the ratio of real shocks to financial shocks.

The remaining part of the paper is organized as follows. Section 2 develops the first stage analysis of the cyclicality of public debt growth for each OECD country and each year covered by our panel data set. In Section 3, we regress GDP growth on financial development, the cyclicality coefficients computed in the first-stage regressions, and the interaction between the two. In Section 4, we uncover some main determinants of the cyclicality of public debt. Finally, Section 5 concludes.

\section{First stage regressions: the cyclicality of pub- lic spending in the cross-country panel}

\subsection{Data}

Panel data on GDP, the GDP gap (ygap), the GDP deflator, government gross debt (ggf), total government disbursements (ypgt), government investment (igaa) and government consumption (cgaa), are taken from the OECD Economic Outlook annual series ${ }^{3}$. Total government disbursements include government investment, government consumption, debt repayment, subsidies to the

\footnotetext{
\begin{tabular}{ccccccr}
\hline${ }^{3}$ Codes & in & parenthesis & indicate & the names & of & vari- \\
ables in & the & dataset. & Full & documentation & available & at
\end{tabular} http://www.oecd.org/findDocument/0,2350,en_2649_34573_1_119669_1_1_1,00.html. Data can be downloaded from sourceoecd.org for subscribers to that service.
} 
private sector, social security and other related transfers, capital transfers and government consumption of fixed capital. Note that debt and other government data refer to general government. Financial development is measured by the ratio of private credit to GDP, and annual cross-country data for this measure of financial development can be drawn from the Levine database ${ }^{4}$. In this latter measure, private credit is all credit to private agents and therefore includes credit to households. The average years of education in the population over 25 years old series is directly borrowed from the Barro-Lee dataset; this measure is only available every five years and has been linearly interpolated to obtain a yearly series. The openness variable is defined as exports and imports over GDP and data on it come from the Penn World Tables 6.1. The population growth, government share of GDP, investment share of GDP also come from the Penn World Tables 6.1. All nominal variables are deflated using the GDP deflator. Summary statistics can be found in Table 1. The sample is an unbalanced panel including the following countries: Australia, Austria, Belgium, Canada, Denmark, Spain, Finland, France, United Kingdom, Germany ${ }^{5}$, Greece, Iceland, Italy, Japan, Netherlands, Norway, New Zealand, Portugal, Sweden, USA.

\subsection{Rationale for the specification of the first stage}

The baseline model for public debt growth as a function of the output gap, comes from the tax-rate-smoothing model by Barro (1979). In this framework, deficits emerge from temporary deviations of government expenditure from "normal" and from temporary deviations of the tax base, assumed to be represented by real GDP, from "normal." Since tax-rate smoothing relates to the ratio of public debt to GDP, an interaction of the level of debt with anticipated growth of GDP also factors into budget deficits. Moreover, given the way that real deficits are usually calculated in the national accounts (corresponding to changes in nominal debt divided by a price index), it is the growth of nominal GDP that matters. That is, anticipated inflation influences the "real" deficit.

We assume that the relevant tax base is proportional to real GDP, $y_{t}$. We assume further that smoothing of the relevant marginal tax rates (for example, on labor income or consumption or value added) corresponds to smoothing the average tax rates, $T_{t} / y_{t}$, where $T_{t}$ is real taxes collected in year $t$.

Let $g_{t}$ be real government expenditure on purchases and transfers. Suppose that $\log \left(g_{t}\right)$ deviates temporarily from its trend, $\left[\log \left(g_{t}\right)\right]^{*}$. Formally, the trend should correspond to the expected present value of expenditure. In practice, we use an H-P filter to estimate the trend in $\log \left(g_{t}\right)$. The deviation, $\log \left(g_{t}\right)-$ $\left[\log \left(g_{t}\right)\right]^{*}$, is the proportionate departure of $g_{t}$ from normal. Multiplying by the trend or normal value, $\left(g_{t}\right)^{*}$, gives the amount of real debt issue required to

\footnotetext{
${ }^{4}$ Data downloadable at http://www.econ.brown.edu/fac/Ross_Levine/Publication/CrossCountryFinStructure.zip.

${ }^{5}$ All level variables are adjusted for the German reunification. The adjustement involves regressing each variable of interest on time and a constant in the ten years before 1991 (data based on West Germany only). We then use the estimated coefficients to predict the values for 1991 to 2000 . We take the average ratio between actual and predicted values in the years 1991 to 2000 . We use this ratio to proportionally adjust values before 1991 .
} 
finance temporary expenditure (rather than having temporarily high tax rates).

Suppose that $\log \left(y_{t}\right)$ deviates temporarily from its trend, $\left[\log \left(y_{t}\right)\right]^{*}$. A positive value corresponds to a boom and a negative one to a recession. Again, we use an H-P filter (or, alternatively, measures of capacity output) to calculate $\left[\log \left(y_{t}\right)\right]^{*}$. Given the behavior of $g_{t}$, tax-rate smoothing implies that a temporary excess of $\log \left(y_{t}\right)$ from $\left[\log \left(y_{t}\right)\right]^{*}$ calls for an equi-proportionate excess of real taxes, $T_{t}$, from normal. Normal real taxes correspond to normal or trend expenditure, $\left(g_{t}\right)^{*}$. Therefore, the product of $\log \left(y_{t}\right)-\left[\log \left(y_{t}\right)\right]^{*}$ and $\left(g_{t}\right)^{*}$ gives the budget surplus (corresponding to a temporarily high level of real taxes collected) associated with a boom.

Given $\log \left(g_{t}\right)-\left[\log \left(g_{t}\right)\right]^{*}$ and $\log \left(y_{t}\right)-\left[\log \left(y_{t}\right)\right]^{*}$, tax-rate smoothing calls for expanding the level of real debt, $b_{t}$, along with expansions of real GDP, $y_{t}$. That is, if $\log \left(g_{t}\right)=\left[\log \left(g_{t}\right)\right]^{*}$ and $\log \left(y_{t}\right)=\left[\log \left(y_{t}\right)\right]^{*}$, the debt-GDP ratio should stay constant. Therefore, the change in the real debt, $b_{t}-b_{t-1}$, includes a term $\gamma b_{t-1}$, where $\gamma$ is the (trend) growth rate of real GDP.

The national accounts typically measure the real budget deficit as the real value of the change in the nominal debt (because nominal government expenditure includes interest payments computed from the nominal interest rate). When measured this way, tax-rate smoothing implies that the real budget deficit includes another term, $\pi b_{t-1}$, where $\pi$ is the (expected) inflation rate. That is, the measured real budget deficit depends on the overall term $(\gamma+\pi) b_{t-1}$, where $\gamma+\pi$ is the growth rate of nominal GDP.

The term $(\gamma+\pi) b_{t-1}$ should move closely with the real value of nominal interest payments. The difference is that nominal interest payments depend on the real interest rate, $r$, rather than the growth rate of real GDP, $\gamma$. If we generate a dependent variable by subtracting the real value of nominal interest payments from the measured real budget deficit, the coefficient on the variable $b_{t-1}$ on the right-hand side should be $\gamma-r$, which we treat as a constant. This constant would be negative in the standard deterministic model. (However, with uncertainty, the real rate $r$ on government debt could be smaller than $\gamma$, the mean growth rate of real GDP.)

The baseline tax-smoothing model has no tendency for the debt-GDP ratio to revert to a stationary mean, such as zero. (More generally, the ratio might revert to something positive, possibly dependent on other assets held by the government.) If there were a tendency for the debt-GDP ratio to revert toward zero, we might pick up this effect from the coefficient on the stock of real debt, $b_{t-1}$. Thus, a negative coefficient on $b_{t-1}$ could represent this mean reversion, along with the effect $\gamma-r$ already mentioned.

Our empirical counterpart of the tax-rate smoothing model of budget deficits is then for each country $i$ : 


$$
\begin{aligned}
\frac{\left(b_{i t}-b_{i, t-1}\right)-i_{i t}}{y_{i t}}= & a_{1 i t} y_{\text {gap }, i t} \frac{\overline{g_{i t}}}{\frac{y_{i t}}{}} \\
& +a_{2 i t}\left\{\ln \left(g_{i t}\right)-\overline{\ln \left(g_{i t}\right)}\right\} \frac{\overline{g_{i t}}}{y_{i t}}+a_{3 i t} \frac{b_{i, t-1}}{y_{i t}}+a_{4 i t}+\varepsilon_{i t} \\
\text { where } \varepsilon_{i t} \sim & N\left(0, \sigma_{\varepsilon}^{2}\right) .
\end{aligned}
$$

Empirically, the variables are defined as follows:

- $b_{i t}$ : gross government debt in country $i$ at year $t$

- $y_{i t}$ : the GDP in country $i$ and year $t$

- $y_{\text {gap }, i t}$ : the GDP gap in country $i$ and year $t$ as computed by the OECD based on a production function approach.

- $i_{i t}$ : interest payments made by the government in country $i$ and year $t$

- $g_{i t}$ : total government disbursements in country $i$ and year $t$

- $\varepsilon_{i t}$ : error term

The $a$ coefficients to be estimated are for the purpose of this paper, assumed to be potentially time-varying, which is why we write $a_{j i t}$ to denote the coefficient on the variable $j$ in country $i$ at time $t$.

A bar above a variable indicates that one takes the prediction for this variable using the Hodrick-Prescott filter. A lambda parameter of 25 was chosen, following $\operatorname{OECD}(1995)$. The prediction was then computed separately for each country.

Note that $b_{i t}-b_{i, t-1}$ is exactly equal to the opposite of the budget balance, so that our left-hand side variable is very close to the opposite of the budget balance as a share of GDP.

With tax smoothing, the predicted coefficients are $a_{1 i t}=-1$ and $a_{2 i t}=1$. The coefficient $a_{3 i t}$ corresponds, as discussed, to $\gamma-r$ (plus a possible negative effect associated with reversion of the debt-GDP ratio toward zero or some other positive target value).

Even if a government does not precisely pursue tax-rate smoothing, the formulation in equation (1) is useful in the sense that the deviations of the estimated coefficients $a$ from the values prescribed under tax smoothing are informative. For example, if $a_{1 i t}<-1$, the government is pursuing a more counter-cyclical deficit policy than called for by tax smoothing, and vice versa if $a_{1 i t}>-1$. A procyclical deficit policy, $a_{1 i t}>0$, is very far from tax-rate smoothing; that is, $a_{1 i t}=0$ is not the natural baseline. We also examine how the extent of counter-cyclical deficit policy varies over time within countries, as well as across countries. 
Finally, when briefly analyzing the cyclicality of government investment or consumption $^{6}$, we just replace government gross debt by these on the left-hand side of equation 1 ; in such specifications, government interest payments are not subtracted on the left-hand side.

\subsection{Econometric methods}

Regression based approaches to measure the cyclicality of fiscal policies are now common in the literature and can be found for example in Lane (2003) and Alesina and Tabellini (2005). However, the methods used in these papers give rise to only one observation of cyclicality per country. In order to make full use of the panel structure of our data, we compute instead for each country yearly measures for the cyclicality of different categories of public spending. A first method, which we do not emphasize in the text, estimates time-varying coefficients by using 10-years rolling window ordinary least squares estimates, a straightforward but very noisy and therefore less reliable method. The second method uses local Gaussian-weighted ordinary least squares estimates (also called kernel-based nonparametric regression or local smoothing): for each year, points that are closer in time are given more weight than points that are further away. The third method is to compute time-varying coefficients in the above equation 1 under the assumption that these coefficients follow an $\mathrm{AR}(1)$ process.

Consider first the ten-year rolling window OLS method: if $v_{i \tau}$ denotes the value of the budgetary variable under consideration (growth of government debt, government investment, or government consumption as defined above) in country $i$ and year $\tau$, then the method simply amounts to estimating the procyclicality of that variable at year $t$ in country $i$ by running the following regression for each country $i$, and all possible $\tau$ :

$$
\begin{aligned}
v_{i \tau} & =a_{1 i t} y_{g a p, i \tau} \frac{\overline{g_{i \tau}}}{y_{i \tau}}+a_{2 i t}\left\{\ln \left(g_{i \tau}\right)-\overline{\ln \left(g_{i \tau}\right)}\right\} \frac{\overline{g_{i \tau}}}{y_{i \tau}}+a_{3 i t} \frac{b_{i, \tau-1}}{y_{i \tau}}+a_{4 i t}+\varepsilon_{i \tau}, \\
\text { for } \tau & \in(t-5, t+4) .
\end{aligned}
$$

that is, one uses a ten year centered rolling window to estimate the pro-cyclicality of the budgetary variable at any date $t$. This method suffers however from serious shortcomings. First, by definition, we lose the first five years and the last four years of data for each country. Second, because the method involves estimating a coefficient by discarding at each time period one old observation and taking into account a new one, the coefficient can vary substantially when the new observation is very different from the one it replaces. This implies that the series may be jagged and affected by noise and transitory changes; moreover, a sudden jump in the series would not be coming from changes in the immediate neighborhood of date $t$, but from changes 5 years before and 4 years after. To

\footnotetext{
${ }^{6}$ In the remainder of the paper, we will often loosely talk about procyclicality or cyclicality of public debt, investment or consumption. All these terms always refer to the $a_{1}$ coefficient in equation 1 when estimated with a left-hand side variable based on either debt, investment or consumption.
} 
avoid these problems we decided instead to implement two alternative methods for our first stage estimations.

The first method we use is local Gaussian-weighted ordinary least squares. The method is very similar in spirit to the 10-years rolling window. But, instead of taking only ten observations at a time, we take all the observations and we weigh them by a Gaussian centered at date $t$. Again the regressions are run separately for each country $i$.

$$
\begin{aligned}
v_{i \tau} & =a_{1 i t} y_{g a p, i \tau} \frac{\overline{g_{i \tau}}}{y_{i \tau}}+a_{2 i t}\left\{\ln \left(g_{i \tau}\right)-\overline{\ln \left(g_{i \tau}\right)}\right\} \frac{\overline{g_{i \tau}}}{y_{i \tau}}+a_{3 i t} \frac{b_{i \tau-1}}{y_{i \tau}}+a_{4 i t}+\varepsilon_{i \tau}, \\
\text { where } \varepsilon_{i \tau} & \sim N\left(0, \sigma^{2} / w_{t}(\tau)\right) \text { and } w_{t}(\tau)=\frac{1}{\sigma \sqrt{2} \Pi} \exp \left(-\frac{(\tau-t)^{2}}{2 \sigma^{2}}\right) .
\end{aligned}
$$

In practice, we use $\sigma=5$. The choice was made to obtain sufficient smoothing of the estimates. While there is some arbitrariness in this choice, choosing 10 years rather than 8 or 12 is just as arbitrary in the case of the 10-years rolling window method. By contrast with the latter method, weighed regressions allow us to use all the data points for our estimates. Moreover, under this method, jumps in the coefficients are mainly due to changes in the immediate neighborhood of date $t$, as those observations in the immediate neighborhood of date $t$ are given highest weight.

The second and preferred method, assumes that coefficients, instead of being independant over time as in ordinary least squares regressions, follow an $\mathrm{AR}(1)$ process, namely, using the notation from equation 1, for each country $i$ and for each coefficient $j$ :

$$
a_{j i t}=a_{j i, t-1}+\varepsilon_{i t}^{a_{j}}, \varepsilon_{i t}^{a_{j}} \sim N\left(0, \sigma_{a_{j}}^{2}\right) .
$$

The main challenge in this case is to estimate $\sigma_{a_{j}}^{2}$ (the variance of the coefficient) at the same time as the variance of the observation, i.e. the variance $\sigma_{\varepsilon}^{2}$ in the formulation of equation 1 . Once these variances are estimated, applying the Kalman smoother gives the best estimates for $a_{j i t}$. These equations can be estimated separately for each country using the VC (for varying coefficients) program by Ekkehart Schlicht ${ }^{7}$. This program uses a method to estimate variances that gives estimates asymptotically equivalent to maximum likelihood estimates ${ }^{8}$. The optimal solution is hard to compute as it involves

\footnotetext{
${ }^{7}$ The program and its documentation are downloadable from: http://www.semverteilung.vwl.uni-muenchen.de/mitarbeiter/frameset_es.htm.

${ }^{8}$ Because of the similarity to a maximum likelihood method such as the EM (ExpectationMaximization) algorithm, this program runs into the local maximum problem. That is, it is in some cases possible to maximize likelihood by assuming that the variance is zero. While this is indeed a solution to the problem, it is only a local maximum. In this paper, we are seeking estimates that show the variation in time of the policy variables of interest. This technical problem is then also a conceptual problem: we do not believe a variance of zero to be a reasonable solution, as it implies time-invariant estimates. It is possible to use an approximate method that mitigates this problem using the Schlicht program, and we have done so in a previous version of the paper.
} 
Bayesian inference in a complicated hierarchical model. While finding analytical closed form solutions turns out to be virtually impossible, Markov Chain Monte Carlo (MCMC) methods provide a feasible numerical approximation. We implement the method in Matlab, assuming, in a panel-like fashion, that the variances of the coefficients and equations are the same for all countries. We are thus left with five variances to estimate: four for the coefficient processes $\left(\sigma_{a_{j}}^{2}, j=1,2,3,4\right)$ and one for the variance of the error in the equation $\left(\sigma_{\varepsilon}^{2}\right)$. Intuitively, the MCMC method explores randomly (using a Markov chain, hence the name) a wide spectrum of possible values for the variances, and one then retains a set that is representative of probable values given the data. In practice, the estimates obtained using this method are highly correlated with the modified Schlicht method used in a previous version of this paper. The advantage of the MCMC method is that it does not get stuck in local solutions and properly represents uncertainty about the variances. The results obtained from this technique ${ }^{9}$ thus do not suffer from the usual overfitting problems and the data analysis becomes more meaningful.

The three estimation methods for the first stage entail different statistical properties and underlying assumptions about the processes at play. From a statistical point of view, the rolling window method relies on less data than the local Gaussian-weighted OLS and AR(1) approaches. The last two approaches are more reliable because they use the whole available data to estimate the coefficients and they proceed in a more structured way.

The difference between the different estimation methods is meaningful from an economic point of view. Indeed, with the AR(1) method, it is assumed that the cyclicality of public spending only changes slowly over time and always follows the same underlying laws as defined by the estimated variances of the coefficients. By contrast, in the case of the rolling window approach, a sudden substantial change in the cyclicality of public spending is not ruled out. Moreover, no persistence of underlying parameters is assumed in the long run: indeed, the coefficient estimated, say 15 years after the start of the data series uses a completely different set of observations from the coefficient estimated 5 years after the start of the data series. The Gaussian-weighted OLS lies between the $\operatorname{AR}(1)$ and the 10-years rolling window methods: on the one hand, it does not directly assume any persistence of the coefficient so that the latter is allowed to change in an unconstrained way; on the other hand, the wider the Gaussian used for weighing observations, the smoother the coefficient estimates over time. Thus, "small" changes (or noise) are smoothed out, but yet "big" changes remain visible, the meaning of big and small depending on the width of the Gaussian.

Overall, we believe that the assumptions underlying the Gaussian-weighted OLS and the AR(1) model are more reasonable than the OLS rolling window both from a statistical and economic perspective, hence our choice to emphasize Gaussian-weighted OLS and AR(1) results in the text, while the 10-years rolling window results are relegated in the appendix 3. Appendix 2 shows the results

\footnotetext{
${ }^{9}$ See the technical appendix for more details on the implementation of this method.
} 
from the procyclicality estimations with all three methods.

\subsection{Results}

We now use the Gaussian-weighted OLS and $\operatorname{AR}(1)$ methods to characterize the level and time path of the procyclicality of government debt in the OECD countries in our sample.

Table 1 summarizes the descriptive statistics of our main variables of interest. It is worth noting that the three different methods used in the first stage to estimate procyclicality give very similar results. We note that gross debt is countercyclical (negative coefficient) while public consumption and investment are procyclical (positive coefficient). These findings are consistent with Lane (2003), who finds that government investment and consumption are procyclical, and that the primary surplus is procyclical, which in turn is equivalent to saying that government debt is countercyclical. Moreover, the mean of our gross debt procyclicality estimate is very close to -1 for all methods considered, which is in line with the tax smoothing model described above.

\section{TABLE 1 HERE}

We now look at the evolution of the procyclicality of public debt growth, as measured by the estimated coefficients $a_{1 i t}$ from equation 1 . Figure 1 shows the evolution of the procyclicality of debt for the US estimated by the three methods described above. We can readily see that, as expected, the 10 years rolling window yields most volatile results, and the AR(1) method the smoothest with the Gaussian-weighted OLS method lying in between. Overall, all three methods show a decrease in procyclicality over time, with a recent trend towards increasing procyclicality shown by the 10 years rolling window and Gaussianweighted OLS methods.

\section{FIGURE 1 HERE}

In Figure 2, we then show the procyclicality of public debt estimated through the AR(1) method for a few countries in our sample. In general, and in line with US trends, procyclicality tends to diminish over time, especially since the 1980's. This downward trend in procyclicality is however more pronounced for the UK and the US than for the average of EMU countries. Also, one can observe

some divergence between EMU and non-EMU countries: at the beginning of the period, the procylicality of public debt growth in EMU countries was very similar to that in the US or the UK, however, as of the 1990's, the US and the UK became significantly more countercyclical whereas the EMU did not.

FIGURE 2 HERE

In Figure 3, we plot the same evolution, however based on coefficients that are estimated using the Gaussian-weighted OLS. As can be seen, trends in estimates are very similar to those obtained using the AR(1) method. 
These results are consistent with Gali and Perotti (2003), who show, splitting their sample by decades, that in general fiscal deficits in the OECD have become more countercyclical, but less so in EMU countries. Here, we confirm these results using a full-fledged time-series measure of cyclicality.

To summarize our results from first stage regressions, we found that government debt has become more countercyclical in non-EMU countries than in EMU countries since the 1990s.

\section{Second stage regressions: the effect of coun- tercyclical budgetary policies on growth}

In this section we regress growth on the cyclicality coefficients derived for each budgetary variable in the first stage regressions of the previous section, financial development, the interaction between the two variables, and a set of controls. Our conjecture is that the more firms are credit constrained, that is, the lower financial development, the more growth-enhancing countercyclical budgetary policies should be to the extent that they reduce the costs that negative liquidity shocks impose on credit-constrained firms. The underlying idea, modelled by $\mathrm{AABM}$, is that, in an economy with tight credit constraints, the occurrence of a recession forces a number of firms to cut on innovative investments in order to survive idiosyncratic liquidity shocks.

To reduce the negative consequences of a recession (or a bad aggregate shock) on firms' innovative investments, the government may decide to increase the volume of its public investments, or public consumption, or to subsidize consumer credit in order to foster the demand for private firms' products. Alternatively, the government may choose to directly increase its subsidies to private enterprises, thereby increasing their liquidity holdings and thus making it easier for them to face idiosyncratic liquidity shocks without having to sacrifice $R \& D$ or other types of longer-term growth-enhancing investments. However, this may have the perverse effect of softening firms' budget constraints, thereby partly undermining the potential innovation-enhancing effect of recessions.

That government intervention might increase aggregate efficiency in an economy subject to credit constraints and aggregate shocks, has already been pointed out by Holmstrom and Tirole (1998). Our analysis in this section can be seen as a first attempt to explore potential empirical implications of this idea for the relationship between growth and public spending over the cycle.

\subsection{Theoretical background}

The following toy model is directly adapted from AABM and ABRR. Consider an economy composed of a continuum of firms, each of which lives for two periods. A firm born at date $t$ produces at that date according to

$$
y_{t}=a_{t}
$$


where $a_{t}$ denotes the knowledge adjusted level of aggregate productivity. At the beginning of date $t$, the firm can also invest in $\mathrm{R} \& \mathrm{D}$. Investing $\mathrm{R} \& \mathrm{D}$ effort $\frac{1}{2} z^{2}$, allows the firm innovate in period $(t+1)$ with probability $z$, provided the firm overcomes an idiosyncratic liquidity shock occurring at the end of period $t$. For simplicity, suppose that the liquidity shock $\widetilde{c}$ is independently and identically distributed across firms with uniform distribution over the interval $[0,1]$, whereas the aggregate shock $a_{t}$ over time is distributed according to

$$
a_{t}=\left\{\frac{1+\varepsilon \text { with probability } 1 / 2}{1-\varepsilon \text { with probability } 1 / 2} .\right.
$$

The long-term $R \& D$ investment yields a (knowledge-adjusted) value equal to $\nu>0$ in period $(t+1)$ whenever innovation is successful. The investment decision is made before the realization of the aggregate shock $a_{t}$. Finally, credit market imperfections prevent a firm with short-run profit flow $a$ to invest more than $\mu a$, where $1<\mu<\infty$, for the purpose of covering its idiosyncratic liquidity $\operatorname{cost} \widetilde{c}$.

Before aggregate productivity $a_{t}$ is realized, firms will choose to invest in R\&D the amount of effort

$$
z^{*}=\arg \max \left\{V z-\frac{1}{2} z^{2}\right\}=V,
$$

where

$$
V=\nu \cdot \mathbb{E}_{t}\left(\min \left[1, \mu a_{t}\right]\right),
$$

with $\mathbb{E}_{t}$ denoting to the expected value at date $t$, and where

$$
\min \left[1, \mu a_{t}\right]=\operatorname{Pr}\left(\widetilde{c} \leq \mu a_{t}\right)
$$

is the probability of the firm overcoming its liquidity shock in period $t$ conditional upon $a_{t}$.

One can easily show that a mean-preserving spread of $a_{t}$ will reduce $V$ and therefore the firm's incentive to invest in R\&D as it will reduce the expected probability of overcoming the liquidity shock. It will thus also reduce more the expected growth rate which we take to be equal to the expected innovation flow:

$$
g_{t}=z^{*} \mathbb{E}_{t}\left(\min \left[1, \mu a_{t}\right]\right)=\nu\left\{\mathbb{E}_{t}\left(\min \left[1, \mu a_{t}\right]\right)\right\}^{2} .
$$

A countercyclical public debt policy that consists in taxing individuals when $a_{t}=1+\varepsilon$ in order reduce the incidence of a low $a_{t}=1+\varepsilon$ on firms' short term profits, should then be growth-enhancing, and all the more so when $\mu$ is lower.

\subsection{Empirical specifications}

In all the specifications we use for our second-stage regressions, we measure productivity growth by the first difference of the log of real GDP per capita. We shall regress this left hand side variable on the lagged cyclicality of public debt growth as derived in the first stage regressions, the lagged private credit 
measure captured by the ratio of private credit to GDP and borrowed from Levine (2001), and the interaction between those two variables. As control variables, we use the lag of log real GDP per capita, the level of schooling, openness to trade, inflation ${ }^{10}$, population growth, and the government share of total GDP. Moreover, in all specifications and unless otherwise specified, we weigh each observation by the inverse of the variance of the estimated cyclicality coefficient (aweights in Stata), thus giving higher weight to coefficients that are more precisely estimated in the first stage.

Each of the tables we present here are structured as follows. Using the set of cyclicality measures derived in the first stage respectively from the Gaussianweighted least squares and AR(1) methods, we first perform ordinary least squares regressions (first column). We then move on to country fixed effect estimates (second column). As is typical in panel growth regressions and can be confirmed by the Wooldridge test implemented in Stata's xtserial command, the errors are serially correlated $(\operatorname{AR}(1))$ in first differences ${ }^{11}$. This implies that country fixed effect estimates may be biased. To correct for this potential source of bias, we use Stata's xtregar command, which implements the method described in Batalgi (2001) to estimate the coefficient of correlation between the errors and give unbiased estimates (third column). Xtregar allows the use of weights ${ }^{12}$, but the weights can only be country specific and not observation specific $^{13}$. We therefore weigh observations by the inverse of the average variance of first-stage estimates for each country. Lastly, we include year fixed effects on top of country fixed effects and estimate these specifications, respectively without and with correction for $\mathrm{AR}(1)$ in the error term (fourth and fifth columns).

\subsection{Results}

Table 2 shows the results of regressing the first difference of the log of real GDP per capita over the lagged cyclicality of government debt, measured by the coefficients obtained in the first stage regression using the AR(1) method. The prediction is that of a negative coefficient for the effect on growth of the procyclicality of public debt, and of a positive coefficient on procyclicality interacted with financial development, and we see that the corresponding coefficients in Table 2 always have the desired signs.

However, it is only when we control for country or country year fixed effects that the results become significant and they are indeed significant at the $5 \%$ or

\footnotetext{
${ }^{10}$ While we do not directly address monetary policy in this work, controlling for inflation allows to indirectly take into account the effect of monetary policy on growth.

${ }^{11}$ This is true whether or not we include the lagged dependant variable, i.e. lag of log real GDP per capita.

${ }^{12}$ In principle, GMM Arellano-Bond or Blundell-Bond estimates could also usefully address this problem. In practice, these methods as implemented with Stata do not allow for weights, which makes them considerably less useful in the context of this paper. We did however try to use these methods without weights, but they never passed essential specification tests, which is one further reason not to rely on them in this specific case.

${ }^{13}$ Moreover, the use of weights restricts the range of methods available to calculate the coefficient of the AR(1) process in the errors. We chose the "regress" method here.
} 
even at the $1 \%$ level. The magnitude of coefficients also increases when adding country fixed effects as compared to OLS. In the last two columns, the further addition of year effects slightly decreses the magnitude of the coefficients and their significance. Allowing for an $\operatorname{AR}(1)$ structure in the error term in columns 3 and 5 does not significantly affect the results.

Table 2 is thus consistent with the prediction of a negative effect of procyclicality in public debt on growth, whereas we see a positive and significant interaction effect between private credit and the procyclicality variable. Thus the less financially developed a country is, the more growth-enhancing it is for the government to be countercyclical in its debt policy.

\section{TABLE 2 HERE}

Table 3 below repeats the same exercises as in Table 2 but now the lagged cyclicality of public debt measures are those derived from first-stage regressions using the Gaussian-weighted least squares method. Results are very similar in magnitude and significance to the ones presented in Table 2 . The only noticeable difference is that the coefficient on the interaction term between procyclicality of public debt and private credit over GDP is smaller and no longer significant when adding both country and year fixed effects. This might be due to the Gaussian weighted method being noisier than the AR(1) method, a presumption which is reinforced by the fact that moving from the Gaussian to the even noisier 10-year OLS rolling window method removes the significance of all coefficients, as shown in Table 1 in the Appendix 3. However, it must be noted that part of this loss of significance is due to a higher sensitivity of results to the inclusion of the lagged depedant variable (that is $\operatorname{lag}(\log ($ real GDP per capita) $)$ in the case of the 10-years rolling window method. This arises because there non negligeable correlation between lagged private credit over GDP, lagged log of GDP per capita and the cyclicality measure, implying that including the lagged depedant variable worsens multicolinearity problems. In Table 2 of Appendix 3, we thus repeat the same exercise as in Table 1 of Appendix 3, and find that results are more often significant when excluding the lagged dependant variable. Results are now significant for both the main term and the interaction with country fixed effects, and remain significant for the interaction when including year fixed effects while the main effect is then only significant at $22 \%$. It is still the case however that the significance disappears when accounting for the $\operatorname{AR}(1)$ structure in the error term in columns 3 and 5. Even with the 10 years rolling window method, a cruder and noisier estimation procedure, we thus find some evidence that less countercyclical public debt policy is harmful for economic growth, and even more so when financial development is lower.

\section{TABLE 3 HERE}

To get a better sense of the magnitude of the effects of public debt cyclicality on growth and the interaction of these effects with financial development, we can ask the following question: according to our estimates, what would happen if public debt in the EMU became as countercyclical as that in the US? Table 
4 summarizes the answer to this question, which is based on the estimates in columns 5 of Tables 2 and 3 , that is on the most demanding specification with both country and year fixed effects and correction for an AR(1) structure in the error term. Thus, if the EMU's government debt was to become as countercyclical as that in the US, which corresponds to a reduction in procyclicality equal to 1.18 units, then the EMU would gain 0.72 points of growth if using the $\operatorname{AR}(1)$ method (Panel A) and 0.84 points of growth when using the Gaussian-weighted OLS method (Panel B). By contrast, if the US was to reduce its procyclicality by the same 1.18 units, it would grow less by up to 5.7 points (Panel A).

\section{TABLE 4 HERE}

Next, we investigate whether these results are driven more by government investments, or by government consumption. This part of our analysis is highly tentative and exploratory, and in particular it relies on the ad hoc assumption that the cyclicality of the various components of public spending would respond to the same right hand side variables as the growth of public debt and according to the same kind of equation. Tables 5 and 6 show the results of the analysis for respectively public consumption and investment using the AR(1) MCMC method. Results are broadly insignificant for public consumption (Table 5), while for public investment (Table 6) they are similar to those found for public debt. However, a procyclical public investment seems to be significantly diminishing growth irrespective of the level of financial development, as the interaction between the procyclicality of public investment and private credit over GDP is typically insignificant. On the other hand, when using the Gaussian-weighted rolling window for the second stage (Tables 3 and 4 in Appendix 3) we find the results for public consumption to be more similar to those for public debt than the results for public investment. We therefore conclude that there is some evidence that procyclical public investment and consumption are harmful for growth, and possibly even more so when a country is less financially developed. However, these results are more tentative and sensitive to the first-stage methods and specifications used than in the case of public debt. Part of the reason for less clear-cut results might be stemming from the fact that it is inadequate to use the same first-stage specification for public consumption and investment as for public debt.

\section{TABLE 5, 6 HERE}

One interesting conclusion from the above analysis, is that EMU countries should have public debt policies that are more countercyclical, or at least as countercyclical, than in the US. On the other hand, the US are more financially developed than the EU (the ratio of private credit to GDP in 2000 in the EU is equal 0.92 against 2.17 in the US, and this difference abstracts from differences in stock market and venture capital market development), and therefore one might wonder whether growth in the US might actually benefit from a reduction in the countercyclicality of public debt policy. Our regressions in Tables 2 and 3 and our calculations in Table 4 suggest that this might indeed be the case: since 
the US decrease growth by getting more countercyclical, the linear specification used in our model implies that at their level of financial development they could increase growth by becoming less countercyclical.

Finally, these conclusions raise the issue of whether or to which extent individual countries can control the degree of public debt countercyclicality. Part of the answer may involve the cost at which governments can borrow from domestic or foreign capital markets, and whether this cost is itself procyclical or countercyclical. This brings us to the following section on the determinants of the cyclicality of public debt.

\section{Determinants of the cyclicality of public debt}

We now investigate possible explanations for the observed differences in the procyclicality of public debt policy across countries in our sample and over time. Since our sample is restricted to OECD countries, little variation should be expected from the corruption or other institutional variables considered by the literature so far ${ }^{14}$. Instead, we will focus on potential explanatory variables such as financial development or openness, that may affect governments' ability to borrow over the cycle or the cost for them to do so. We also include GDP growth volatility as measured by the standard error of GDP growth, lag of log real GDP per capita, the government share of GDP, and EMU membership ${ }^{15}$ as control variables. Financial development is a plausible suspect as it influences both the ability and the willingness of governments to borrow. While OECD countries are arguably less subject to borrowing constraints than other countries in the world, there is still a fair amount of cross-country variation in financial development among OECD countries. Openness is also a plausible candidate as one can expect a higher capital inflow in more open economies during expansion periods, and therefore a lower cost of capital during such periods. This in turn tends to increase the long-run cost of financing countercyclical public debt policies while maintaining the overall debt constant on average over the long run. The EMU dummy is also a plausible candidate, given: (i) our casual observation in the introduction to the effect that the structural deficit appears to be less reactive to the business cycle in the eurozone than in the US or the UK; (ii) the deficit and debt restrictions imposed by the Stability and Growth Pact and also the restrictions that individual countries imposed themselves in order to qualify for EMU membership.

Table 7, where the cyclicality measures are derived using the AR(1) and Gaussian-weighted methods, shows results that are consistent with these conjectures, namely: (i) higher financial development is positively and significantly correlated with the countercyclicality of government debt (the table shows a neg-

\footnotetext{
${ }^{14}$ As mentioned above, using ICRG indicators turns out not to be of interest for our analysis.

${ }^{15}$ This dummy variable takes a value of 1 for all countries that currently belong to the EMU, and 0 for all the other countries. This is because the EMU has been prepared for many years so that the countries that would eventually join might be different even before the EMU is fully effective.
} 
ative coefficient of public debt procyclicality); in other words, it is precisely when the countercyclicality of public debt is more positively correlated with growth, namely when financial development is low, that public debt countercyclicality seems hardest to achieve; (ii) more trade openness is negatively and significantly correlated with public debt countercyclicality (the table shows a positive correlation between openness and public debt procyclicality); (iii) EMU countries appear to have a harder time achieving public debt countercyclicality. The effect of the EMU dummy is more likely to be explained by rigidities already imposed by the precursor EMS regime and then reinforced by the Maastricht Treaty, rather than the 1999 implementation of the EMU itself ${ }^{16}$; further investigation of this question is however beyond the scope of this paper. Finally, we note that higher volatility of GDP growth and a higher share of government in the GDP are associated with a more countercyclical debt policy.

\section{TABLE 7 HERE}

To summarize our discussion in this section, a lower level of financial development, a higher degree of openness, and belonging to the EMU group, enter significantly as explanatory variables to explain a lower degree of countercyclicality in government debt.

\section{Conclusion}

In this paper we have analyzed the dynamics and determinants of the cyclicality of public debt on a yearly panel of OECD countries, and we have analyzed the relationship between public debt countercyclicality, financial development, and productivity growth. Our findings can be summarized as follows: first, countercyclicality has increased over time across all countries in our sample, however to a lower extent in EMU countries than in the US or the UK. Second, countercyclicality of government debt appears to be facilitated by a higher level of financial development while it appears to be complicated by a higher degree of openness to trade. Third, our main finding is that countercyclical public debt policy is more growth enhancing the lower the country's level of financial development.

Our analysis may be criticized on several grounds. First, one might dispute the causal link from public debt countercyclicality to growth, arguing that our second stage regressions simply reflect the fact that growth allows a country to become more countercyclical. Without ruling out the existence of a reverse causality from growth to public debt policy over the cycle, and in the absence of a good experiment or instrument, the case can still be made to support the claim that reverse causality is not plaguing our main results. First, if all there is, is that countries with higher average growth can afford to be more countercyclical, then country fixed effects would account for this. Second, we use lagged and

\footnotetext{
${ }^{16}$ We have thus experimented with an interaction between the EMU dummy and a post-1999 dummy, but this interaction was typically insignificant, indicating that there is no substantial change occuring with the full implementation of the EMU in 1999.
} 
not current policy cyclicality; in fact, we can show that future cyclicality is not significantly correlated with growth whereas past cyclicality is so correlated at several lags, thereby further supporting the idea that cyclicality Granger-causes growth and not the reverse.

More generally, we have an endogeneity problem if unobserved determinants of cyclicality or financial development also influence growth. If these determinants are country-specific and time-invariant, once again the inclusion of country fixed-effects cure it. Moreover, year fixed effect account for unobserved determinants that are time-varying and common to all countries. Thus, the endogeneity problem only arises with time-variant country-specific factors that are unobserved or uncontrolled for. What our analysis suggests is that openness cannot be such a factor, as higher openness is negatively correlated with public debt countercyclicality whereas it is positively correlated with growth.

Another potential problem arises from the fact that because GDP growth and GDP gap are positively correlated, the effect of procyclicality (estimated coefficient on GDP gap) on growth will mechanically tend to be negative, creating a spurious negative correlation between procyclicality and growth automatically by construction. However, we use the lagged value of procyclicality and, while current growth and GDP gap are indeed positively correlated, current growth and the lagged GDP gap are uncorrelated ${ }^{17}$.

Finally, in light of our second stage regressions, one may wonder whether the EMU should really change its policy given that financial development is increasing in the EMU over time, boosted by the monetary union itself. However, based on the historical growth trend of financial development, the EMU will not reach the current level of financial development of the USA until year 2084. Even based on the faster growth trend of financial development of the 1990's, the EMU will only reach the USA level of financial development in 2068. On the other hand the USA, according to our estimates, might be too countercyclical. In order for more countercyclicality to be no longer growth enhancing for the EMU, and based on growth trend of financial development of the 1990's, the EMU would still have to wait for several decades (at least until between 2020 and 2030, depending on which specification we base our estimates on).

We now conclude by mentioning some possible research avenues. First, one could try to perform the same kind of analysis for other groups of countries, e.g middle income countries in Latin America or in Central and Eastern Eu-

\footnotetext{
${ }^{17}$ While this makes us fairly confident in our results, it does not completely rule out some degree of spurious correlation between GDP growth and procyclicality. Indeed, by construction our first stage estimates of procyclicality do not rely only on the curret value of the right-hand side variables (including GDP gap). In the Gaussian weighted OLS method, current GDP gap is however given more weight than future or past GDP gaps, so lagged procylicality depends more on lagged than current GDP gap. In the AR(1) method, by the AR(1) assumption the value of the current cyclicality coefficient depends only on the past value of the cyclicality coefficient and not on future values. Thus lagged cyclicality depends primarily on lagged GDP gap and even further lags of the GDP gap, and not on the current GDP gap. The use of the Kalman smoother does however introduce some small degree of feedback between future and past values of the coefficient. However, all in all, the AR(1) method should be resistant to the bias arising from spurious correlation.
} 
rope. Second, one could explore potential implications of the relationship between growth and the countercyclicality of budgetary policy for the conduct of monetary policy. For example, to which extent allowing for some inflation or for higher procyclicality of short term interest rates, increases governments' borrowing costs during recessions, and thereby improves their ability to implement growth-enhancing countercyclical budgetary policies? Preliminary work with Enisse Kharroubi suggests that inflation is less negatively correlated with growth, the higher a country's degree of public debt procyclicality. Third, one could analyze in more detail which types of countercyclical public spending (consumption, investment) are most growth-enhancing, and on which sectors. Finally, one could investigate the possible interactions between countercyclical budgetary policy and structural reforms in the product and labor markets.

\section{References}

[1] Acemoglu, D, Johnson, S, Robinson, J, and Y. Thaicharoen (2003), "Institutional Causes, Macroeconomic Symptoms: Volatility, Crises, and Growth", Journal of Monetary Economics, 50,49-123.

[2] Aghion, P, Angeletos, M, Banerjee, A, and K. Manova (2005), "Volatility and Growth: Credit Constraints and Productivity-Enhancing Investment", NBER Working Paper No 11349.

[3] Aghion, P, Bacchetta, P, Ranciere, R, and K. Rogoff (2006), "Exchange Rate Volatility and Productivity Growth: The Role of Financial Development", NBER Working Paper No 12117.

[4] Alesina, A, and R. Perotti. (1996), "Fiscal Adjustments in OECD Countries: Composition and Macroeconomic Effects", NBER Working Paper No 5730 .

[5] Alesina, A, and G. Tabellini (2005), "Why is Fiscal Policy often Procyclical?", NBER Working Paper No 11600.

[6] Barro, R (1979), "On the Determination of Public Debt", Journal of Political Economy, 87, pp. 940-971.

[7] Batalgi, B (2001), Econometric Analysis of Panel Data, 2d ed. New York: John Wiley \& Sons.

[8] Calderon, C, Duncan, R, and K. Schmidt-Hebbel (2004), "Institutions and Cyclical Properties of Macroeconomic Policies", Central Bank of Chile Working Papers No 285.

[9] Chib,S, and E. Greenberg (1995), "Understanding the Metropolis-Hastings Algorithm", The American Statistician, 49, 327-335. 
[10] Easterly, W, (2005), "National Policies and Economic Growth: A Reappraisal", Chapter 15 in Handbook of Economic Growth, P. Aghion and S. Durlauf eds.

[11] Gali, J, and R. Perotti (2003), "Fiscal Policy and Monetary Integration in Europe", Economic Policy, 533-572.

[12] Kording K. and Marinescu I. (2006), "Sampling approaches to Kalman learning", work in progress.

[13] Lane, P, (2002), "The Cyclical Behavior of Fiscal Policy: Evidence from the OECD", Journal of Public Economics, 87, 2661-2675.

[14] Lane, P, and A. Tornell (1998), "Why Aren't Latin American Savings Rates Procyclical?, Journal of Development Economics, 57, 185-200.

[15] OECD (1995), "Estimating Potential Output, Output Gaps and Structural Budget Balances", by Claude Giorno, Pete Richardson, Deborah Roseveare and Paul van den Noord, OECD Economics Department Working Paper No. 152.

[16] Talvi, E, and C. Vegh (2000), "Tax Base Variability and Procyclical Fiscal Policy", NBER Working Paper No 7499. 
Table 1: Summary statistics

\begin{tabular}{|c|c|c|c|c|c|}
\hline & Obs. & Mean & Std. Dev. & Min & Max \\
\hline GDP gap & 764 & -0.001 & 0.028 & -0.109 & 0.160 \\
\hline Gross government debt/GDP & 756 & 0.501 & 0.283 & 0.044 & 1.608 \\
\hline (d.Gross government debt-interests)/GDP & 754 & 0.008 & 0.041 & -0.113 & 0.195 \\
\hline Government consumption/GDP & 1029 & 0.182 & 0.045 & 0.057 & 0.301 \\
\hline d.Government consumption/GDP & 1003 & 0.017 & 0.011 & -0.009 & 0.081 \\
\hline Government investment/GDP & 966 & 0.036 & 0.011 & 0.012 & 0.115 \\
\hline d.Government investment/GDP & 939 & 0.003 & 0.005 & -0.016 & 0.041 \\
\hline Procyclicality of gross government debt (AR(1)) & 612 & -0.925 & 1.042 & -4.206 & 1.447 \\
\hline $\begin{array}{l}\text { Procyclicality of gross government debt (10-years } \\
\text { rolling window) }\end{array}$ & 454 & -1.179 & 1.923 & -9.259 & 3.466 \\
\hline $\begin{array}{l}\text { Procyclicality of gross government debt (weighted } \\
\text { rolling window) }\end{array}$ & 643 & -1.072 & 1.169 & -4.000 & 1.951 \\
\hline Procyclicality of government consumption (AR(1)) & 605 & 0.126 & 0.209 & -0.850 & 0.771 \\
\hline $\begin{array}{l}\text { Procyclicality of government consumption (10-years } \\
\text { rolling window) }\end{array}$ & 425 & 0.133 & 0.240 & -0.767 & 0.891 \\
\hline $\begin{array}{l}\text { Procyclicality of government consumption (weighted } \\
\text { rolling window) }\end{array}$ & 605 & 0.143 & 0.161 & -0.368 & 0.584 \\
\hline Procyclicality of government investment (AR(1)) & 605 & 0.073 & 0.061 & -0.108 & 0.286 \\
\hline $\begin{array}{l}\text { Procyclicality of government investment (10-years } \\
\text { rolling window) }\end{array}$ & 425 & 0.093 & 0.142 & -0.588 & 0.574 \\
\hline $\begin{array}{l}\text { Procyclicality of government investment (weighted } \\
\text { rolling window) }\end{array}$ & 605 & 0.077 & 0.092 & -0.314 & 0.399 \\
\hline Growth of GDP per capita & 1117 & 0.027 & 0.029 & -0.942 & 0.199 \\
\hline $\begin{array}{l}\text { Private credit/GDP } \\
\text { Average years of schooling for the population over } 25\end{array}$ & 983 & 0.679 & 0.437 & 0.013 & 2.370 \\
\hline years old & 1078 & 7.691 & 2.285 & 1.940 & 12.250 \\
\hline Openness & 1242 & 50.131 & 40.938 & 3.648 & 266.883 \\
\hline Inflation & 1212 & 0.085 & 0.125 & -0.105 & 1.408 \\
\hline Population growth & 1132 & 0.008 & 0.008 & -0.038 & 0.047 \\
\hline Government share of GDP (in \%) & 1241 & 13.292 & 5.779 & 3.008 & 32.115 \\
\hline Investment/GDP (in\%) & 1241 & 23.325 & 5.407 & 8.208 & 41.635 \\
\hline
\end{tabular}

Source: OECD Economic Outlook, Levine dataset, Barro Lee dataset, Penn World Tables 6.1. 
Figure 1: the procyclicality of public debt in the USA

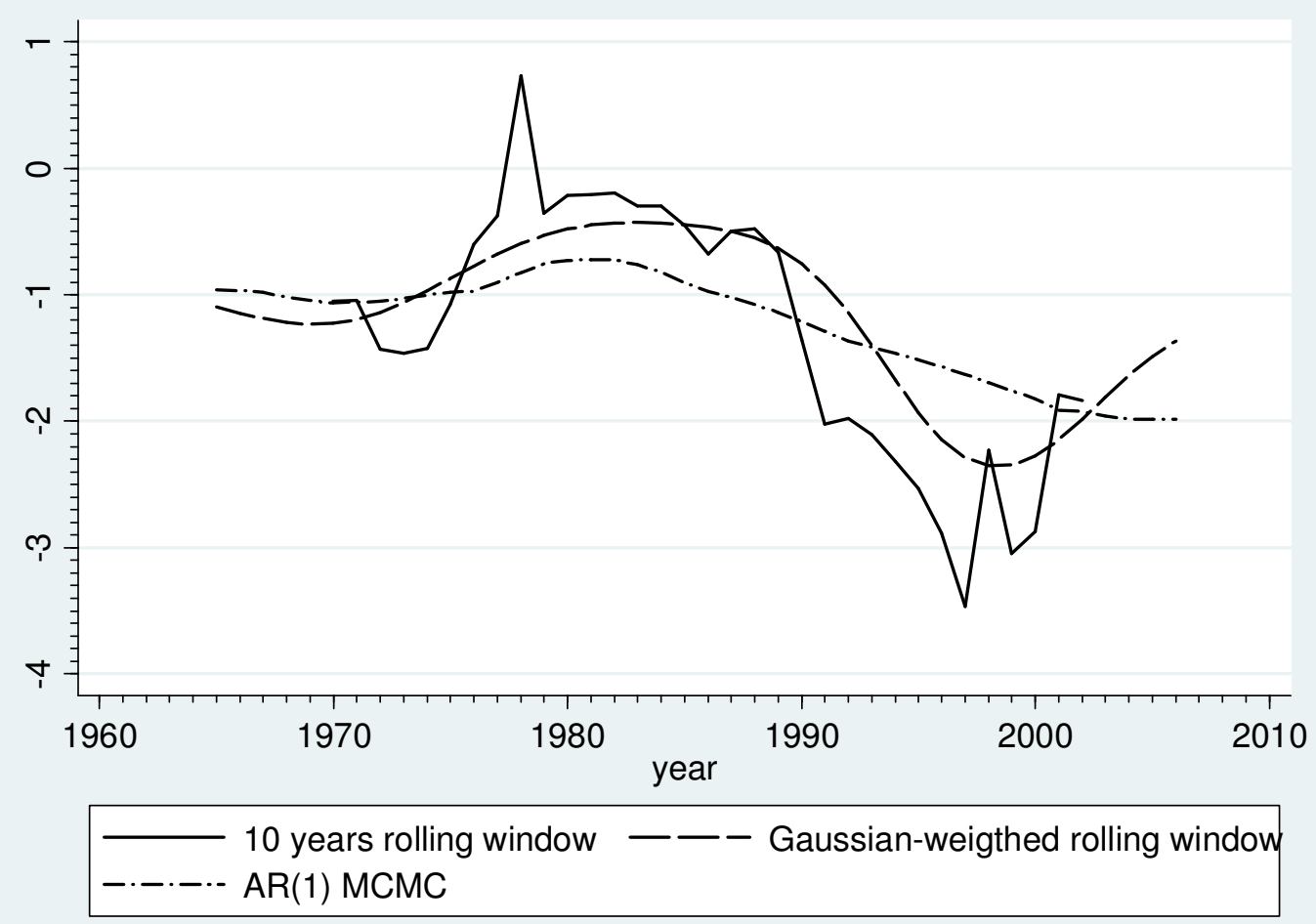

Note: the graph plots the $a_{1 i t}$ coefficients, i.e. the coefficients on the output gap composite variable (see equation 1 ), using various estimation techniques. Source: OECD Economic Outlook. 
Figure 2: The procyclicality of public debt using the AR(1) MCMC method

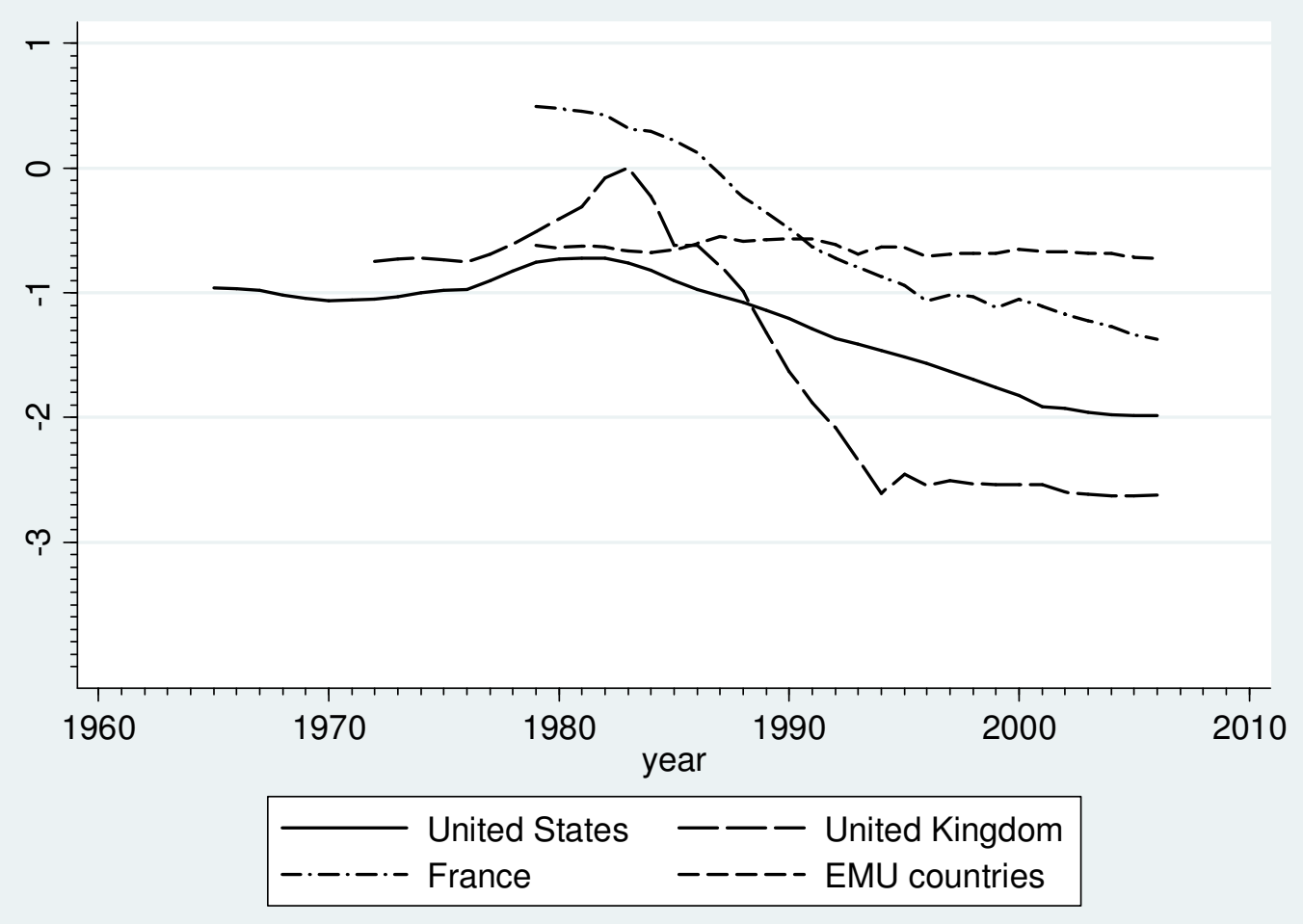

Note: the graph plots the $a_{1 i t}$ coefficients, i.e. the coefficients on the output gap composite variable (see equation 1), using the AR(1) MCMC method. For EMU countries (i.e. countries who are or will be part of the EMU), the line represents the average of the estimated coefficients for the EMU countries present in the sample; the average is only computed for those years where all EMU countries have non-missing observations.

Source: OECD Economic Outlook. 
Figure 3: The procyclicality of public debt using the Gaussian-weighted OLS method

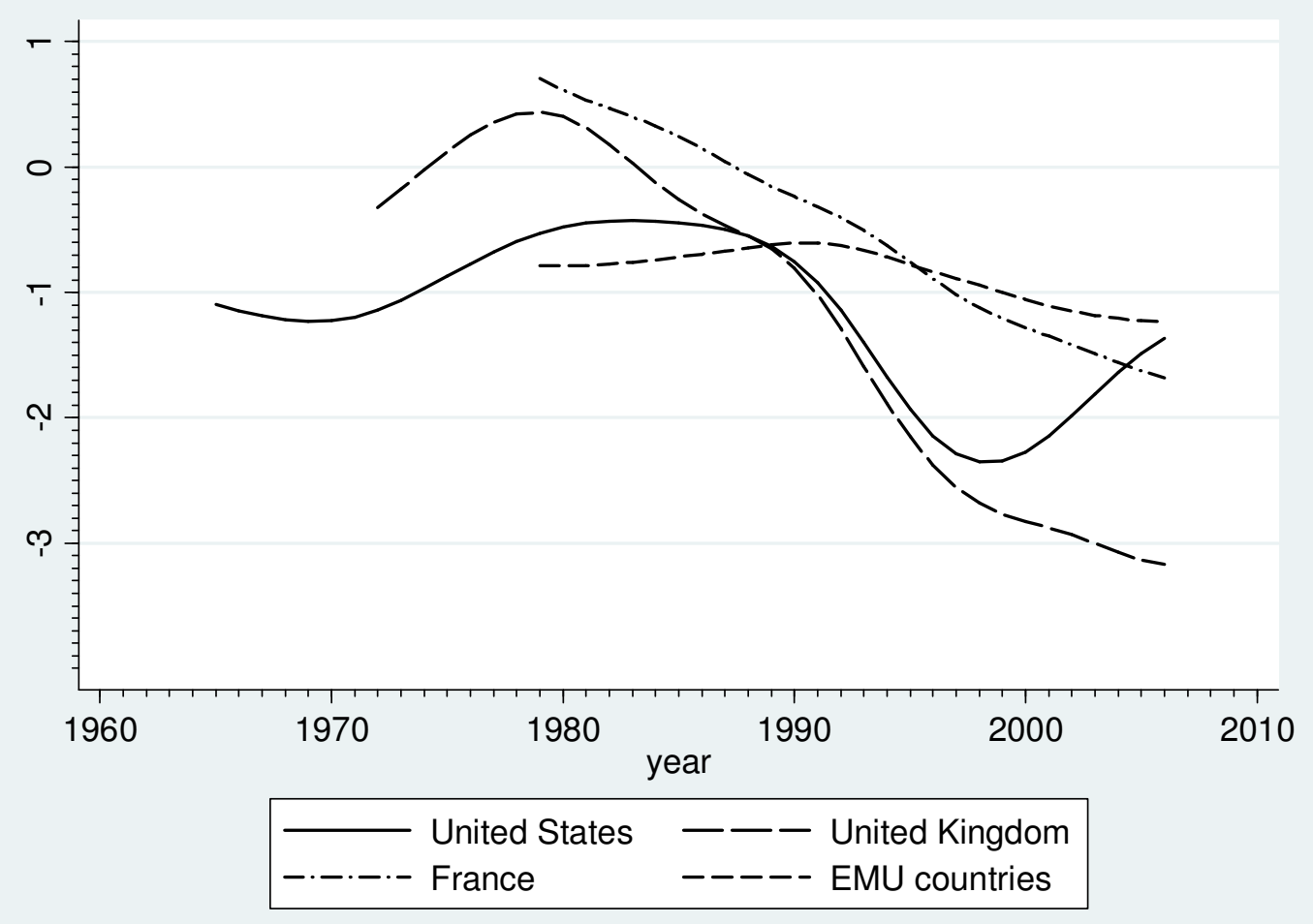

Note: the graph plots the $a_{1 i t}$ coefficients, i.e. the coefficients on the output gap composite variable (see equation 1), using the Gaussian-weighted rolling window OLS method. For EMU countries (i.e. countries who are or will be part of the EMU), the line represents the average of the estimated coefficients for the EMU countries present in the sample; the average is only computed for those years where all EMU countries have non-missing observations.

Source: OECD Economic Outlook. 
Table 2: The effect of public debt procyclicality on growth, AR(1) MCMC method

\begin{tabular}{|c|c|c|c|c|c|}
\hline & \multirow[t]{2}{*}{ OLS } & \multicolumn{2}{|c|}{ Country f.e. } & \multicolumn{2}{|c|}{ Country year f.e. } \\
\hline & & Standard & $\begin{array}{l}\text { Corrected for } \\
\text { AR(1) errors }\end{array}$ & Standard & $\begin{array}{l}\text { Corrected for } \\
\text { AR(1) errors }\end{array}$ \\
\hline \multirow{3}{*}{$\begin{array}{l}\text { lag(Procyclicality of government } \\
\text { debt) } \\
\text { lag(Private credit/GDP) }\end{array}$} & $\begin{array}{l}-0.004 \\
\text { * }\end{array}$ & $\begin{array}{l}-0.023 \\
\text { * }\end{array}$ & $\begin{array}{l}-0.022 \\
(0.008)^{\star \star \star *}\end{array}$ & $\begin{array}{l}-0.015 \\
(0.005)^{* * *}\end{array}$ & $\begin{array}{l}-0.018 \\
(0.007)^{* *}\end{array}$ \\
\hline & $(0.002)^{*}$ & $(0.005)^{\star \star \star}$ & $(0.008)^{\star \star \star}$ & $(0.005)^{\star \star \star}$ & $(0.007)^{\star \star}$ \\
\hline & $\begin{array}{l}0.000 \\
(0.005)\end{array}$ & $\begin{array}{l}-0.003 \\
(0.009)\end{array}$ & $\begin{array}{l}0.010 \\
(0.012)\end{array}$ & $\begin{array}{l}-0.012 \\
(0.009)\end{array}$ & $\begin{array}{l}-0.011 \\
(0.011)\end{array}$ \\
\hline \multirow{3}{*}{$\begin{array}{l}\text { lag(Procyclicality of government } \\
\text { debtPrivate credit/GDP) } \\
\text { lag(log (real GDP per } \\
\text { capita)) }\end{array}$} & 0.004 & 0.017 & 0.017 & 0.011 & 0.014 \\
\hline & -0.001 & -0.098 & -0.177 & -0.134 & -0.276 \\
\hline & $(0.001)$ & $(0.015)^{\star * *}$ & $(0.020)^{\star \star \star}$ & $(0.023)^{\star \star \star}$ & $(0.030)^{\star \star \star}$ \\
\hline \multirow{4}{*}{$\begin{array}{l}\text { Average years of schooling for the } \\
\text { population over } 25 \text { years old } \\
\text { Openness }\end{array}$} & -0.001 & 0.007 & 0.018 & 0.005 & 0.009 \\
\hline & $(0.001)$ & $(0.003)^{\star \star}$ & $(0.004)^{\star * *}$ & $(0.003)^{\star *}$ & $(0.004)^{\star \star}$ \\
\hline & 0.000 & 0.001 & 0.001 & 0.001 & 0.000 \\
\hline & $(0.000)$ & $(0.000)^{* * *}$ & $(0.000)^{\star \star *}$ & $(0.000)^{\star *}$ & $(0.000)$ \\
\hline \multirow[t]{2}{*}{ Inflation } & -0.047 & -0.071 & -0.094 & -0.043 & -0.055 \\
\hline & $(0.021)^{\star \star}$ & $(0.021)^{* * *}$ & $(0.022)^{\star * *}$ & $(0.022)^{*}$ & $(0.021)^{\star *}$ \\
\hline \multirow[t]{2}{*}{ Population growth } & -1.250 & -2.085 & -2.278 & -1.481 & -1.571 \\
\hline & $(0.405)^{\star \star \star}$ & $(0.317)^{\star \star *}$ & $(0.246)^{* * *}$ & $(0.283)^{\star \star *}$ & $(0.230)^{\star * *}$ \\
\hline \multirow[t]{2}{*}{ Government share of GDP (in \%) } & 0.000 & -0.001 & -0.001 & -0.001 & -0.001 \\
\hline & $(0.000)$ & $(0.000)^{* *}$ & $(0.000)^{* *}$ & $(0.000)^{*}$ & $(0.000)^{*}$ \\
\hline \multirow[t]{2}{*}{ Investment/GDP (in\%) } & 0.001 & 0.003 & 0.004 & 0.002 & 0.004 \\
\hline & $(0.000)^{\star * *}$ & $(0.000)^{\star * *}$ & $(0.000)^{\star * *}$ & $(0.000)^{\star * *}$ & $(0.000)^{\star * *}$ \\
\hline \multirow[t]{2}{*}{ Constant } & -0.005 & -0.906 & -1.672 & -1.151 & -2.242 \\
\hline & $(0.021)$ & $(0.136)^{\star \star \star}$ & $(0.093)^{\star \star \star}$ & $(0.192)^{\star \star \star}$ & $(0.113)^{\star \star \star}$ \\
\hline Observations & 460 & 441 & 441 & 441 & 441 \\
\hline R-squared & 0.17 & 0.4 & & 0.61 & \\
\hline \multicolumn{6}{|c|}{ Robust standard errors in parentheses } \\
\hline
\end{tabular}

Note: The explained variable is the first difference of the log of real GDP per capita. In columns 3 and 5, we allowed for $A R(1)$ autocorrelation in the error term by using Stata's command xtregar, which implements the method described in Batalgi (2001).

Source: OECD Economic Outlook, Levine dataset, Barro Lee dataset, Penn World Tables 6.1. 
Table 3: The effect of public debt procyclicality on growth, Gaussian-weighted OLS method

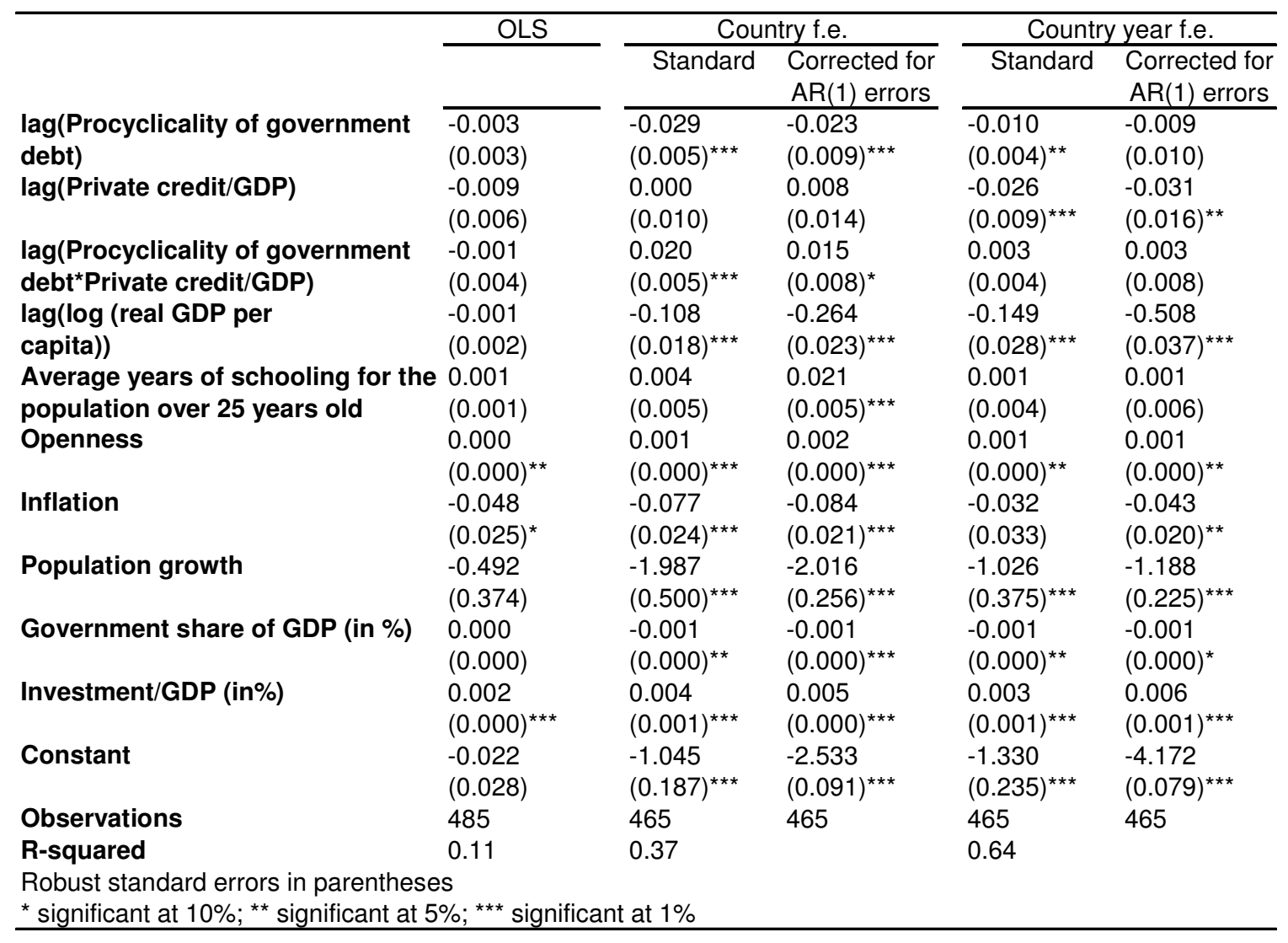

Note: The explained variable is the first difference of the log of real GDP per capita. In columns 3 and 5, we allowed for $A R(1)$ autocorrelation in the error term by using Stata's command xtregar, which implements the method described in Batalgi (2001).

Source: OECD Economic Outlook, Levine dataset, Barro Lee dataset, Penn World Tables 6.1. 
Table 4: Implied effect on growth of a change in the procyclicality of public debt such that the EMU would have the same level of procyclicality as the US in 2000

\begin{tabular}{|c|c|c|c|c|c|c|c|c|c|c|}
\hline & $\begin{array}{l}\text { Estimated coef. } \\
\text { on lag } \\
\text { (Procyclicality } \\
\text { of government } \\
\text { debt) }\end{array}$ & & $\begin{array}{l}\text { Difference US- } \\
\text { EMU }\end{array}$ & & $\begin{array}{l}\text { Estimated coef. } \\
\text { lag(Procyclicality } \\
\text { of government } \\
\text { debt }^{\star} \text { private } \\
\text { credit/GDP) }\end{array}$ & $\begin{array}{l}\text { Difference US- } \\
\text { EMU }\end{array}$ & & $\begin{array}{l}\text { Average( } \\
\text { lag } \\
\text { (private } \\
\text { credit/ } \\
\text { GDP)) }\end{array}$ & & $\begin{array}{l}\text { Implied } \\
\text { effect on } \\
\text { growth }\end{array}$ \\
\hline \multicolumn{11}{|c|}{ Panel A: AR(1) } \\
\hline EMU in 2000 & -0.0180 & * & -1.1840 & + & 0.0140 & -1.0943 & * & 0.9242 & $=$ & 0.0072 \\
\hline US in 2000 & -0.0180 & * & -1.1840 & + & 0.0140 & -2.5688 & * & 2.1696 & $=$ & -0.0567 \\
\hline \multicolumn{11}{|l|}{ Panel B: WRW } \\
\hline$\overline{E M U}$ in 2000 & -0.0090 & * & -1.2990 & + & 0.0030 & -1.2006 & * & 0.9242 & $=$ & 0.0084 \\
\hline US in 2000 & -0.0090 & * & -1.2990 & + & 0.0030 & -2.8184 & * & 2.1696 & $=$ & -0.0067 \\
\hline
\end{tabular}

Note: The estimated coefficients are taken from estimates columns 5 of Tables 2 (Panel A) and 3 (Panel B). The difference US-EMU is defined as: (procyclicality of government debt in the US in 2000)- (procyclicality of government debt in the EMU in 2000). The averages of variables are calculated using the same sample on which regressions were estimated.

Source: OECD Economic Outlook, Levine dataset, Barro Lee dataset, Penn World Tables 6.1. 
Table 5: The effects of government consumption procyclicality on growth, AR(1) MCMC method

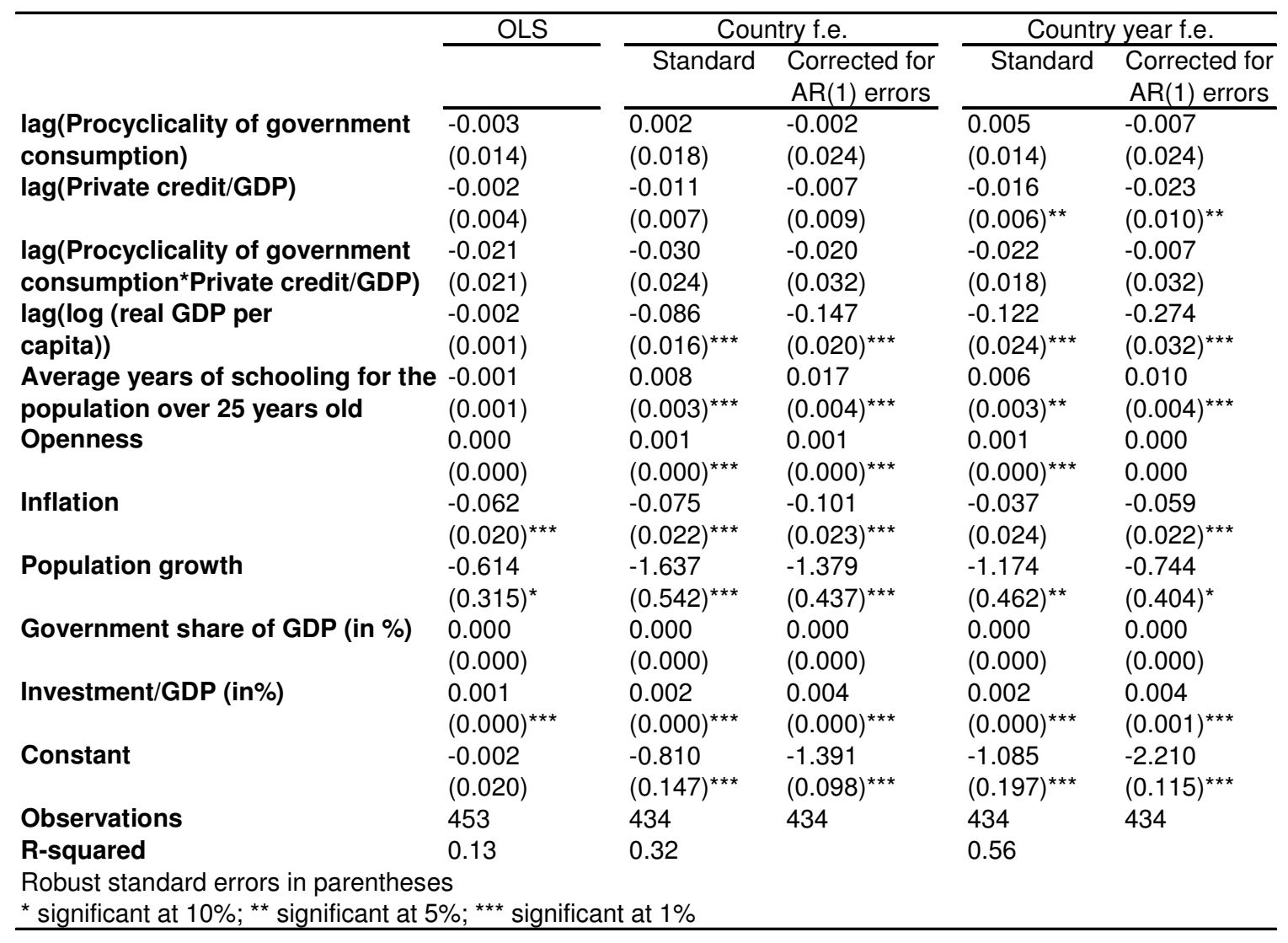

Note: The explained variable is the first difference of the log of real GDP per capita. In columns 3 and 5, we allowed for AR(1) autocorrelation in the error term by using Stata's command xtregar, which implements the method described in Batalgi (2001).

Source: OECD Economic Outlook, Levine dataset, Barro Lee dataset, Penn World Tables 6.1. 
Table 6: The effects of public investment procyclicality on growth, AR(1) MCMC method

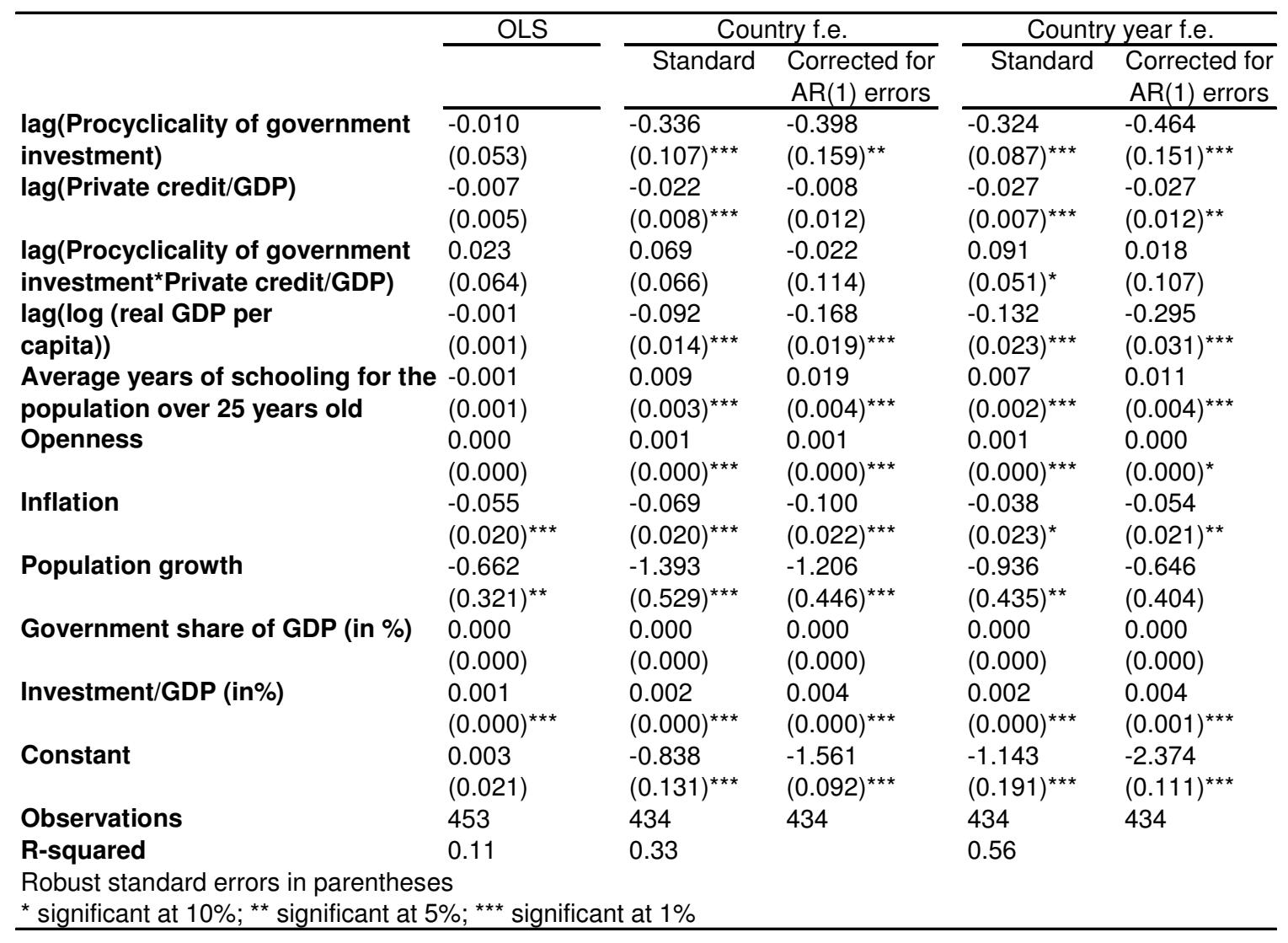

Note: The explained variable is the first difference of the log of real GDP per capita. In columns 3 and 5, we allowed for $A R(1)$ autocorrelation in the error term by using Stata's command xtregar, which implements the method described in Batalgi (2001).

Source: OECD Economic Outlook, Levine dataset, Barro Lee dataset, Penn World Tables 6.1. 
Table 7: The determinants of government debt procyclicality

\begin{tabular}{|c|c|c|c|c|c|c|}
\hline & \multicolumn{3}{|c|}{$\mathrm{AR}(1)$} & \multicolumn{3}{|c|}{ WRW } \\
\hline & OLS & $\begin{array}{l}\text { Country } \\
\text { f.e. }\end{array}$ & $\begin{array}{l}\text { Country } \\
\text { year f.e. }\end{array}$ & OLS & $\begin{array}{c}\text { Country } \\
\text { f.e. }\end{array}$ & $\begin{array}{l}\text { Country } \\
\text { year f.e. }\end{array}$ \\
\hline Private credit/GDP & $\begin{array}{l}-0.567 \\
(0.162)^{\star \star \star}\end{array}$ & $\begin{array}{l}-1.079 \\
(0.124)^{\star \star *}\end{array}$ & $\begin{array}{l}-0.959 \\
(0.132)^{\star \star \star}\end{array}$ & $\begin{array}{l}-0.569 \\
(0.114)^{\star \star *}\end{array}$ & $\begin{array}{l}-0.894 \\
(0.134)^{\star \star \star}\end{array}$ & $\begin{array}{l}-0.912 \\
(0.143)^{\star \star \star}\end{array}$ \\
\hline EMU country & $\begin{array}{l}0.395 \\
(0.103)^{* * *}\end{array}$ & & & $\begin{array}{l}0.165 \\
(0.083)^{\star *}\end{array}$ & & \\
\hline $\begin{array}{l}\text { Standard error } \\
\text { of GDP growth }\end{array}$ & $\begin{array}{l}-4.929 \\
(1.571)^{\star * *}\end{array}$ & & & $\begin{array}{l}-8.684 \\
(1.549)^{\star \star \star}\end{array}$ & & \\
\hline $\begin{array}{l}\text { Lag(log (real GDP } \\
\text { per capita)) }\end{array}$ & $\begin{array}{l}0.017 \\
(0.040)\end{array}$ & $\begin{array}{l}-0.543 \\
(0.247)^{\star *}\end{array}$ & $\begin{array}{l}0.270 \\
(0.553)\end{array}$ & $\begin{array}{l}0.030 \\
(0.048)\end{array}$ & $\begin{array}{l}0.206 \\
(0.266)\end{array}$ & $\begin{array}{l}0.475 \\
(0.502)\end{array}$ \\
\hline Openness & $\begin{array}{l}0.005 \\
(0.002)^{\star * *}\end{array}$ & $\begin{array}{l}0.010 \\
(0.003)^{\star * *}\end{array}$ & $\begin{array}{l}0.021 \\
(0.005)^{\star \star \star}\end{array}$ & $\begin{array}{l}-0.003 \\
(0.001)^{\star *}\end{array}$ & $\begin{array}{l}-0.004 \\
(0.004)\end{array}$ & $\begin{array}{l}0.015 \\
(0.005)^{\star \star \star}\end{array}$ \\
\hline $\begin{array}{l}\text { Government share } \\
\text { of GDP (in \%) }\end{array}$ & $\begin{array}{l}-0.019 \\
(0.010)^{\star \star}\end{array}$ & $\begin{array}{l}-0.012 \\
(0.005)^{\star *}\end{array}$ & $\begin{array}{l}-0.025 \\
(0.005)^{\star \star \star}\end{array}$ & $\begin{array}{l}0.004 \\
(0.007)\end{array}$ & $\begin{array}{l}-0.009 \\
(0.006)\end{array}$ & $\begin{array}{l}-0.022 \\
(0.007)^{\star \star \star}\end{array}$ \\
\hline Constant & $\begin{array}{l}-0.286 \\
(0.559)\end{array}$ & $\begin{array}{l}-4.700 \\
(2.083)^{\star *}\end{array}$ & $\begin{array}{l}1.443 \\
(4.736)\end{array}$ & $\begin{array}{l}0.455 \\
(0.545)\end{array}$ & $\begin{array}{l}2.123 \\
(2.341)\end{array}$ & $\begin{array}{l}3.611 \\
(4.307)\end{array}$ \\
\hline Observations & 489 & 489 & 489 & 515 & 515 & 515 \\
\hline R-squared & 0.11 & 0.86 & 0.87 & 0.18 & 0.77 & 0.79 \\
\hline $\begin{array}{l}\text { Robust standard errc } \\
\text { * significant at } 10 \% \text {; }\end{array}$ & $\begin{array}{l}\text { parenthes } \\
\text { nificant at }\end{array}$ & 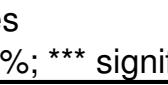 & & & & \\
\hline
\end{tabular}

Note: The explained variable is the coefficient on the GDP gap composite variable from equation 1, estimated using the $A R(1) M C M C$ method for columns 1-3, and the Gaussian-weighted rolling window method for columns 4-6. EMU country is a dummy variable equal to 1 for all countries that are part of the EMU as of 2006.

Source: OECD Economic Outlook, Levine dataset, Barro Lee dataset, Penn World Tables 6.1. 


\section{Appendix 1: the AR(1) MCMC method for cal- culating cyclicality in the first stage}

The aim of this section is to give a brief description of how we used the Kalman smoother together with Markov Chain Monte Carlo methods (MCMC) in order to estimate the coefficients $a_{j i t}$ from equation 1 under the assumption that they follow an $\mathrm{AR}(1)$ process as desribed by equation 2 . The implementation was carried out in Matlab.

Estimating the means and variances of the coefficients of interest - that is $a_{j i t}$ in equation 2 - involves two procedures: Kalman smoothing ${ }^{1}$ and MCMC.

To compute the coefficients with the Kalman smoother for each country, we need to know the values of five variances:

- $\sigma_{a_{j}}^{2}$ in equation 2 , for $j=1,2,3,4$, i.e. the process variances in the terminology of the Kalman smoother

- the variance $\sigma_{\varepsilon}^{2}$ of the error term $\varepsilon_{t}$ in equation 1, i.e. the measurement error variance in the terminology of the Kalman smoother.

Moreover, to use the Kalman smoother, we need a prior for the first period of observation for each country, that is a specification of our expectation over the values $a_{j i t}$ at the first time step. As we do not have any meaningful prior information about cyclicality at the first observed period, we use a very high variance around the prior mean, so that this prior has a negligeable effect on the estimates. Specifically, the set of initial values for the coefficients were chosen to be the OLS estimates of the coefficients using the first 10 years of data for each country, and the value of the intial variance is set to be 100000 times the estimated variance of these coefficients.

However, the process variances $\sigma_{a_{j}}^{2}$ and the measurement error variance $\sigma_{\varepsilon}^{2}$ are unknown and we do not have any meaninful prior over them. We therefore need a method to find reasonable values for these five unknown variances. This is where MCMC methods are useful .

One can think of MCMC as the opposite of simulating. In the case of simulation we know the parameters of our process, for example the variances, and every time we run a simulation program, it gives us a set of possible observed data. More specifically, the probability of getting any set of observed data is the probability defined by the model that we have and the parameters. MCMC is the opposite: we assume that we have a given dataset, and we are producing a

\footnotetext{
${ }^{1}$ For an excellent overview of the Kalman filter and smoother, see the notes by Max Welling "Kalman Filters", available on the web at http://www.ics.uci.edu/ ${ }^{\sim}$ welling/classnotes/classnotes.html. The difference between the Kalman filter and smoother is that the latter uses future values as well as past values to estimate the coefficients of interest. We use the Kalman smoother here rather than the filter for two reasons. First, we want to make maximum use of a limited data and the smoother uses more information. Second, given the nature of the problem at hand, the government has to rely on beliefs about future states in order to set policy, so that the future should matter as well as the present in defining policy cyclicality.
} 
set of possible parameters. This is done in such a fashion that the probability of accepting a parameter value is identical to the probability that this parameter value has actually produced the data.

Specifically, in our implementation, we use the classic Metropolis-Hastings (MH) sampler to do MCMC (for an introduction to MCMC and MetropolisHastings, see for example Chib and Greenberg (1995)). In MH one starts with arbitrary parameters values. Every iteration one proposes a random change (in our case a small gaussian change) of the parameters. This is what is called the proposal distribution. Subsequently, this change is either accepted or rejected. The probability of acceptance is:

$$
p_{\text {accept }}=\min \left(1, \frac{p(\text { data } \mid \text { new_parameter } s)}{p(\text { data } \mid \text { previous_parameter } s)}\right)
$$

It is easy to prove that this procedure is actually sampling from the correct posterior distribution over the parameter values.

MCMC algorithms go through two different stages. In the first stage the sampler converges to a probable interpretation of the data in terms of the parameters. This stage is called burn-in and took about 500 iterations in our case. Within these 500 iterations, probabilities increased dramatically and then converged to a stable high level. Afterwards, the MCMC algorithm is exploring the space of relevant parameters. Over 3 runs, we took 10000 samples per run after the end of burn-in. To avoid the autocorrelation that typically characterizes a Markov Chain, we only retain samples every 100 iterations in order to compute the final estimates. From these 3 runs, we thus get a total of 300 essentially uncorrelated samples for each of the five parameters we wish to estimate. Convergence of the Markov chain was assessed comparing the within chain correlation with the across chain correlation. From these 300 samples, we can then directly estimate means and variances of the 5 parameters of interest.

In order to correcly infer the effect of cyclicality on growth in our second stage regressions, we need to determine not only the value of the cyclicality $\left(a_{1 i t}\right)$, but also the uncertainty we have about it. To estimate this uncertainty, or in other words the standard deviation of the cyclicality estimates, it is necessary to consider the relevant sources of uncertainty. Two sources are relevant in our case. One is the uncertainty that is represented by the Kalman smoother that stems from the finite number of noisy observations. The other source of uncertainty is uncertainty about the 5 parameters of the $\mathrm{AR}(1)$ processes that are modeled by the MCMC process. To combine them, we use the approximation variance $_{\text {total }}=$ variance $_{M C M C}+\overline{\text { variance }_{\text {Kalman }}}$, where $\overline{\text { variance }_{\text {Kalman }}}$ denotes the average variance over the 300 Kalman smoother runs using the 300 samples that we retained from the MCMC estimates of the 5 variances. This approximation becomes correct if the variance as estimated by the Kalman smoother is similar over different runs of the Markov chain, which was a good appriximation for our data.

Finally, a full general statistical description of the methods used here can be found in Kording-Marinescu(2006). 


\section{Appendix 2: Procyclicality estimates}

\begin{tabular}{|c|c|c|c|c|c|c|c|c|c|c|}
\hline \multirow[b]{2}{*}{ Year } & \multirow[b]{2}{*}{ Country } & \multicolumn{3}{|c|}{ Procyclicality of public debt } & \multicolumn{3}{|c|}{ Procyclicality of public investment } & \multicolumn{3}{|c|}{ Procyclicality of public consumption } \\
\hline & & 10YRW & WRW & $\mathrm{AR}(1)$ & 10YRW & WRW & $\mathrm{AR}(1)$ & 10YRW & WRW & $\mathrm{AR}(1)$ \\
\hline 1989 & Australia & & -0.337 & -0.693 & & 0.078 & 0.027 & & 0.050 & -0.020 \\
\hline 1990 & Australia & & -0.542 & -0.700 & & 0.070 & 0.026 & & 0.051 & -0.024 \\
\hline 1991 & Australia & & -0.780 & -0.724 & & 0.061 & 0.025 & & 0.051 & -0.018 \\
\hline 1992 & Australia & & -1.032 & -0.786 & & 0.052 & 0.025 & & 0.051 & -0.016 \\
\hline 1993 & Australia & & -1.278 & -0.929 & & 0.044 & 0.024 & & 0.051 & -0.023 \\
\hline 1994 & Australia & -0.224 & -1.503 & -1.154 & 0.082 & 0.037 & 0.023 & 0.089 & 0.051 & -0.024 \\
\hline 1995 & Australia & -1.014 & -1.700 & -1.222 & 0.064 & 0.031 & 0.023 & -0.167 & 0.052 & -0.035 \\
\hline 1996 & Australia & -0.960 & -1.872 & -1.292 & 0.046 & 0.026 & 0.023 & 0.006 & 0.053 & -0.042 \\
\hline 1997 & Australia & -2.375 & -2.025 & -1.363 & 0.040 & 0.023 & 0.023 & 0.109 & 0.053 & -0.049 \\
\hline 1998 & Australia & -4.056 & -2.172 & -1.436 & -0.035 & 0.021 & 0.023 & 0.163 & 0.052 & -0.055 \\
\hline 1999 & Australia & -8.856 & -2.322 & -1.451 & -0.047 & 0.019 & 0.023 & 0.104 & 0.050 & -0.072 \\
\hline 2000 & Australia & -5.228 & -2.485 & -1.438 & 0.054 & 0.017 & 0.023 & -0.279 & 0.045 & -0.041 \\
\hline 2001 & Australia & -4.397 & -2.665 & -1.460 & 0.043 & 0.017 & 0.023 & -0.220 & 0.037 & -0.039 \\
\hline 2002 & Australia & & -2.864 & -1.447 & & 0.016 & 0.023 & & 0.024 & -0.033 \\
\hline 2003 & Australia & & -3.078 & -1.452 & & 0.015 & 0.023 & & 0.007 & -0.031 \\
\hline 2004 & Australia & & -3.297 & -1.444 & & 0.014 & 0.023 & & -0.013 & -0.030 \\
\hline 2005 & Australia & & -3.509 & -1.443 & & 0.012 & 0.023 & & -0.037 & -0.029 \\
\hline$\overline{\overline{1972}}$ & "Austria & & "-0.849 & -0.345 & & "-0.084 & 0.032 & & "-0.095 & 0.277 \\
\hline 1973 & Austria & & -0.797 & -0.362 & & -0.075 & 0.031 & & -0.117 & 0.265 \\
\hline 1974 & Austria & & -0.746 & -0.342 & & -0.068 & 0.031 & & -0.134 & 0.237 \\
\hline 1975 & Austria & & -0.698 & -0.332 & & -0.062 & 0.029 & & -0.144 & 0.160 \\
\hline 1976 & Austria & & -0.652 & -0.290 & & -0.056 & 0.026 & & -0.147 & 0.096 \\
\hline 1977 & Austria & -0.550 & -0.608 & -0.247 & -0.096 & -0.049 & 0.025 & -0.129 & -0.141 & 0.029 \\
\hline 1978 & Austria & -0.655 & -0.568 & -0.253 & -0.022 & -0.040 & 0.024 & -0.260 & -0.125 & 0.014 \\
\hline 1979 & Austria & -0.680 & -0.535 & -0.259 & -0.020 & -0.029 & 0.022 & -0.247 & -0.100 & -0.002 \\
\hline 1980 & Austria & -0.666 & -0.512 & -0.250 & -0.049 & -0.015 & 0.023 & -0.207 & -0.066 & -0.008 \\
\hline 1981 & Austria & -0.226 & -0.500 & -0.233 & -0.009 & 0.000 & 0.024 & -0.207 & -0.028 & 0.010 \\
\hline 1982 & Austria & -0.065 & -0.497 & -0.224 & -0.101 & 0.013 & 0.026 & -0.157 & 0.010 & 0.031 \\
\hline 1983 & Austria & -0.200 & -0.501 & -0.215 & -0.154 & 0.025 & 0.027 & -0.171 & 0.046 & 0.073 \\
\hline 1984 & Austria & -0.650 & -0.508 & -0.188 & -0.062 & 0.033 & 0.027 & -0.168 & 0.076 & 0.106 \\
\hline 1985 & Austria & -0.304 & -0.514 & -0.117 & 0.012 & 0.040 & 0.029 & -0.036 & 0.103 & 0.135 \\
\hline 1986 & Austria & 0.017 & -0.515 & -0.115 & 0.044 & 0.046 & 0.030 & 0.155 & 0.128 & 0.176 \\
\hline 1987 & Austria & -0.253 & -0.508 & -0.079 & 0.058 & 0.053 & 0.034 & 0.232 & 0.154 & 0.233 \\
\hline 1988 & Austria & -0.397 & -0.487 & -0.034 & 0.069 & 0.062 & 0.035 & 0.225 & 0.182 & 0.266 \\
\hline 1989 & Austria & -0.627 & -0.449 & -0.006 & 0.105 & 0.073 & 0.036 & 0.307 & 0.212 & 0.285 \\
\hline 1990 & Austria & -0.666 & -0.395 & 0.008 & 0.103 & 0.086 & 0.037 & 0.309 & 0.243 & 0.298 \\
\hline 1991 & Austria & -0.847 & -0.329 & -0.048 & 0.111 & 0.097 & 0.036 & 0.344 & 0.270 & 0.311 \\
\hline 1992 & Austria & -0.604 & -0.262 & -0.093 & 0.132 & 0.104 & 0.035 & 0.327 & 0.287 & 0.315 \\
\hline 1993 & Austria & -0.717 & -0.199 & -0.063 & 0.058 & 0.104 & 0.034 & 0.293 & 0.290 & 0.302 \\
\hline 1994 & Austria & -1.222 & -0.142 & -0.034 & 0.021 & 0.095 & 0.033 & 0.238 & 0.278 & 0.290 \\
\hline 1995 & Austria & 0.731 & -0.086 & -0.005 & 0.160 & 0.078 & 0.032 & 0.379 & 0.251 & 0.276 \\
\hline 1996 & Austria & 0.364 & -0.031 & 0.034 & 0.108 & 0.054 & 0.030 & 0.170 & 0.213 & 0.259 \\
\hline 1997 & Austria & 0.261 & 0.021 & 0.064 & 0.097 & 0.025 & 0.029 & 0.156 & 0.168 & 0.241 \\
\hline 1998 & Austria & 0.548 & 0.063 & 0.090 & -0.004 & -0.005 & 0.027 & 0.067 & 0.122 & 0.222 \\
\hline 1999 & Austria & 0.404 & 0.091 & 0.130 & -0.074 & -0.033 & 0.025 & -0.018 & 0.081 & 0.183 \\
\hline 2000 & Austria & 0.013 & 0.104 & 0.083 & -0.101 & -0.054 & 0.023 & -0.022 & 0.049 & 0.128 \\
\hline 2001 & Austria & 0.174 & 0.106 & 0.090 & -0.108 & -0.070 & 0.022 & -0.023 & 0.027 & 0.107 \\
\hline 2002 & Austria & & 0.102 & 0.087 & & -0.081 & 0.021 & & 0.013 & 0.092 \\
\hline 2003 & Austria & & 0.100 & 0.081 & & -0.087 & 0.020 & & 0.004 & 0.078 \\
\hline 2004 & Austria & & 0.102 & 0.024 & & -0.091 & 0.019 & & -0.001 & 0.072 \\
\hline 2005 & Austria & & 0.112 & 0.017 & & -0.094 & 0.019 & & -0.004 & 0.077 \\
\hline
\end{tabular}

Note: the table reports the $a_{1 i t}$ coefficients, i.e. the coefficients on the output gap composite variable (see equation 1), using various estimation techniques. 10YRW stands for the 10-years rolling window OLS method, WRW for the Gaussian-weighted rolling window OLS method and $\mathrm{AR}(1)$ for the $\mathrm{AR}(1) \mathrm{MCMC}$ method.

Source: OECD Economic Outlook. 


\begin{tabular}{|c|c|c|c|c|c|c|c|c|c|c|}
\hline \multirow[b]{2}{*}{ Year } & \multirow[b]{2}{*}{ Country } & \multicolumn{3}{|c|}{ Procyclicality of public debt } & \multicolumn{3}{|c|}{ Procyclicality of public investment } & \multicolumn{3}{|c|}{ Procyclicality of public consumption } \\
\hline & & 10YRW & WRW & $\mathrm{AR}(1)$ & 10YRW & WRW & $\mathrm{AR}(1)$ & 10YRW & WRW & $\mathrm{AR}(1)$ \\
\hline 1972 & Germany & & -0.201 & -0.100 & & 0.090 & 0.089 & & 0.010 & 0.219 \\
\hline 1973 & Germany & & -0.153 & -0.165 & & 0.087 & 0.091 & & 0.012 & 0.245 \\
\hline 1974 & Germany & & -0.116 & -0.202 & & 0.086 & 0.095 & & 0.019 & 0.234 \\
\hline 1975 & Germany & & -0.091 & -0.215 & & 0.086 & 0.095 & & 0.029 & 0.181 \\
\hline 1976 & Germany & & -0.077 & -0.197 & & 0.088 & 0.095 & & 0.042 & 0.140 \\
\hline 1977 & Germany & -0.682 & -0.072 & -0.167 & 0.235 & 0.092 & 0.097 & -0.003 & 0.057 & 0.136 \\
\hline 1978 & Germany & -0.087 & -0.078 & -0.101 & 0.116 & 0.097 & 0.100 & 0.071 & 0.073 & 0.157 \\
\hline 1979 & Germany & -0.072 & -0.093 & -0.134 & 0.059 & 0.103 & 0.101 & 0.057 & 0.089 & 0.165 \\
\hline 1980 & Germany & -0.204 & -0.115 & -0.198 & 0.099 & 0.110 & 0.101 & 0.144 & 0.104 & 0.203 \\
\hline 1981 & Germany & -0.075 & -0.144 & -0.251 & 0.196 & 0.118 & 0.100 & 0.348 & 0.114 & 0.207 \\
\hline 1982 & Germany & -0.204 & -0.182 & -0.314 & 0.229 & 0.124 & 0.100 & 0.303 & 0.118 & 0.203 \\
\hline 1983 & Germany & -0.316 & -0.234 & -0.377 & 0.206 & 0.128 & 0.098 & 0.241 & 0.113 & 0.172 \\
\hline 1984 & Germany & -0.261 & -0.307 & -0.430 & 0.178 & 0.129 & 0.096 & 0.177 & 0.100 & 0.150 \\
\hline 1985 & Germany & -0.385 & -0.405 & -0.496 & 0.189 & 0.126 & 0.095 & 0.169 & 0.079 & 0.128 \\
\hline 1986 & Germany & -0.312 & -0.523 & -0.567 & 0.151 & 0.120 & 0.093 & 0.128 & 0.052 & 0.107 \\
\hline 1987 & Germany & -0.394 & -0.653 & -0.640 & 0.173 & 0.112 & 0.091 & -0.143 & 0.024 & 0.082 \\
\hline 1988 & Germany & -1.510 & -0.790 & -0.710 & 0.010 & 0.102 & 0.089 & -0.521 & -0.001 & 0.056 \\
\hline 1989 & Germany & -1.074 & -0.933 & -0.779 & 0.005 & 0.092 & 0.088 & -0.172 & -0.022 & 0.028 \\
\hline 1990 & Germany & -1.480 & -1.079 & -0.810 & -0.039 & 0.083 & 0.087 & -0.281 & -0.034 & 0.037 \\
\hline 1991 & Germany & -1.547 & -1.217 & -0.840 & -0.083 & 0.077 & 0.086 & -0.348 & -0.038 & 0.066 \\
\hline 1992 & Germany & -2.402 & -1.336 & -0.818 & -0.005 & 0.074 & 0.087 & -0.298 & -0.033 & 0.140 \\
\hline 1993 & Germany & -2.516 & -1.430 & -0.835 & 0.015 & 0.074 & 0.087 & -0.281 & -0.020 & 0.166 \\
\hline 1994 & Germany & -2.237 & -1.501 & -0.801 & 0.054 & 0.076 & 0.086 & -0.201 & -0.001 & 0.168 \\
\hline 1995 & Germany & -2.451 & -1.558 & -0.858 & 0.069 & 0.080 & 0.086 & -0.104 & 0.020 & 0.176 \\
\hline 1996 & Germany & -1.795 & -1.610 & -0.783 & 0.155 & 0.084 & 0.085 & 0.324 & 0.043 & 0.184 \\
\hline 1997 & Germany & -1.265 & -1.665 & -0.758 & 0.221 & 0.087 & 0.085 & 0.574 & 0.067 & 0.198 \\
\hline 1998 & Germany & 0.084 & -1.726 & -0.764 & 0.016 & 0.090 & 0.083 & 0.407 & 0.092 & 0.192 \\
\hline 1999 & Germany & -1.037 & -1.793 & -0.746 & 0.122 & 0.091 & 0.082 & 0.258 & 0.115 & 0.190 \\
\hline 2000 & Germany & -2.829 & -1.862 & -0.772 & 0.149 & 0.090 & 0.082 & 0.236 & 0.137 & 0.191 \\
\hline 2001 & Germany & -2.534 & -1.927 & -0.811 & 0.155 & 0.088 & 0.082 & 0.276 & 0.155 & 0.189 \\
\hline 2002 & Germany & & -1.985 & -0.851 & & 0.085 & 0.081 & & 0.169 & 0.186 \\
\hline 2003 & Germany & & -2.032 & -0.860 & & 0.082 & 0.081 & & 0.180 & 0.190 \\
\hline 2004 & Germany & & -2.070 & -0.881 & & 0.080 & 0.080 & & 0.186 & 0.187 \\
\hline 2005 & Germany & & -2.100 & -0.899 & & 0.080 & 0.079 & & 0.191 & 0.178 \\
\hline 1981 & " Denmark & & -2.526 & -3.854 & & 0.059 & 0.042 & & 0.393 & -0.533 \\
\hline 1982 & Denmark & & -2.583 & -4.098 & & 0.049 & 0.042 & & 0.353 & -0.498 \\
\hline 1983 & Denmark & & -2.642 & -4.061 & & 0.039 & 0.042 & & 0.316 & -0.343 \\
\hline 1984 & Denmark & & -2.713 & -3.863 & & 0.031 & 0.040 & & 0.282 & -0.263 \\
\hline 1985 & Denmark & & -2.806 & -3.694 & & 0.024 & 0.039 & & 0.248 & -0.207 \\
\hline 1986 & Denmark & -2.077 & -2.928 & -3.476 & 0.107 & 0.018 & 0.036 & 0.537 & 0.213 & -0.160 \\
\hline 1987 & Denmark & -1.316 & -3.082 & -3.587 & 0.082 & 0.013 & 0.037 & 0.461 & 0.177 & -0.058 \\
\hline 1988 & Denmark & -2.078 & -3.264 & -3.664 & -0.162 & 0.010 & 0.035 & 0.173 & 0.139 & -0.062 \\
\hline 1989 & Denmark & -3.931 & -3.464 & -3.725 & -0.013 & 0.007 & 0.034 & 0.067 & 0.099 & -0.059 \\
\hline 1990 & Denmark & -3.776 & -3.661 & -3.800 & -0.009 & 0.006 & 0.033 & 0.088 & 0.059 & -0.059 \\
\hline 1991 & Denmark & -3.895 & -3.830 & -3.884 & -0.026 & 0.006 & 0.031 & 0.070 & 0.024 & -0.072 \\
\hline 1992 & Denmark & -4.584 & -3.948 & -4.032 & 0.053 & 0.006 & 0.028 & 0.257 & -0.001 & -0.074 \\
\hline 1993 & Denmark & -4.914 & -4.004 & -4.206 & -0.004 & 0.006 & 0.029 & -0.124 & -0.013 & -0.083 \\
\hline 1994 & Denmark & -4.578 & -4.001 & -3.980 & -0.017 & 0.004 & 0.028 & -0.086 & -0.015 & -0.065 \\
\hline 1995 & Denmark & -5.230 & -3.946 & -3.768 & -0.015 & 0.002 & 0.028 & -0.150 & -0.012 & -0.051 \\
\hline 1996 & Denmark & -5.126 & -3.846 & -3.556 & -0.027 & 0.001 & 0.028 & -0.087 & -0.006 & -0.036 \\
\hline 1997 & Denmark & -5.176 & -3.704 & -3.351 & -0.054 & 0.001 & 0.028 & -0.104 & 0.000 & -0.027 \\
\hline 1998 & Denmark & -5.557 & -3.522 & -3.200 & 0.031 & 0.003 & 0.028 & -0.084 & 0.009 & -0.005 \\
\hline 1999 & Denmark & 2.109 & -3.297 & -3.112 & 0.138 & 0.006 & 0.029 & 0.322 & 0.020 & -0.003 \\
\hline 2000 & Denmark & 2.037 & -3.022 & -2.856 & 0.107 & 0.011 & 0.030 & 0.371 & 0.035 & 0.010 \\
\hline 2001 & Denmark & 1.633 & -2.688 & -2.580 & 0.098 & 0.016 & 0.031 & 0.355 & 0.053 & 0.043 \\
\hline 2002 & Denmark & & -2.286 & -2.404 & & 0.023 & 0.031 & & 0.075 & 0.048 \\
\hline 2003 & Denmark & & -1.816 & -2.255 & & 0.030 & 0.031 & & 0.100 & 0.055 \\
\hline 2004 & Denmark & & -1.288 & -2.259 & & 0.037 & 0.030 & & 0.127 & 0.054 \\
\hline 2005 & Denmark & & -0.724 & -2.274 & & 0.044 & 0.030 & & 0.155 & 0.055 \\
\hline
\end{tabular}

Note: the table reports the $a_{1 i t}$ coefficients, i.e. the coefficients on the output gap composite variable (see equation 1), using various estimation techniques. 10YRW stands for the 10-years rolling window OLS method, WRW for the Gaussian-weighted rolling window OLS method and $A R(1)$ for the $A R(1) M C M C$ method.

Source: OECD Economic Outlook. 


\begin{tabular}{|c|c|c|c|c|c|c|c|c|c|c|}
\hline \multirow[b]{2}{*}{ Year } & \multirow[b]{2}{*}{ Country } & \multicolumn{3}{|c|}{ Procyclicality of public debt } & \multicolumn{3}{|c|}{ Procyclicality of public investment } & \multicolumn{3}{|c|}{ Procyclicality of public consumption } \\
\hline & & 10YRW & WRW & $\mathrm{AR}(1)$ & 10YRW & WRW & $\mathrm{AR}(1)$ & 10YRW & WRW & $\mathrm{AR}(1)$ \\
\hline 1978 & Spain & & -3.334 & -2.535 & & -0.145 & 0.084 & & 0.131 & -0.850 \\
\hline 1979 & Spain & & -3.121 & -2.566 & & -0.107 & 0.083 & & 0.123 & -0.802 \\
\hline 1980 & Spain & & -2.892 & -2.596 & & -0.070 & 0.080 & & 0.117 & -0.698 \\
\hline 1981 & Spain & & -2.655 & -2.577 & & -0.035 & 0.078 & & 0.113 & -0.546 \\
\hline 1982 & Spain & & -2.419 & -2.653 & & 0.001 & 0.077 & & 0.112 & -0.430 \\
\hline 1983 & Spain & -5.050 & -2.194 & -2.680 & -0.293 & 0.036 & 0.086 & 0.313 & 0.116 & -0.341 \\
\hline 1984 & Spain & -4.495 & -1.993 & -2.606 & 0.297 & 0.069 & 0.091 & -0.083 & 0.123 & -0.211 \\
\hline 1985 & Spain & -1.570 & -1.829 & -2.332 & 0.295 & 0.098 & 0.095 & 0.078 & 0.133 & -0.118 \\
\hline 1986 & Spain & -1.193 & -1.711 & -2.096 & 0.204 & 0.119 & 0.104 & 0.038 & 0.143 & -0.055 \\
\hline 1987 & Spain & -1.030 & -1.642 & -1.976 & 0.165 & 0.132 & 0.112 & 0.025 & 0.153 & 0.001 \\
\hline 1988 & Spain & -0.813 & -1.616 & -1.860 & 0.213 & 0.139 & 0.120 & 0.021 & 0.162 & 0.078 \\
\hline 1989 & Spain & -1.328 & -1.625 & -1.697 & 0.135 & 0.141 & 0.126 & 0.172 & 0.172 & 0.178 \\
\hline 1990 & Spain & -1.115 & -1.666 & -1.668 & 0.023 & 0.142 & 0.129 & 0.092 & 0.183 & 0.236 \\
\hline 1991 & Spain & -0.883 & -1.738 & -1.771 & 0.137 & 0.142 & 0.128 & 0.098 & 0.197 & 0.292 \\
\hline 1992 & Spain & -0.498 & -1.847 & -1.859 & 0.162 & 0.145 & 0.129 & 0.250 & 0.213 & 0.363 \\
\hline 1993 & Spain & -1.768 & -1.992 & -1.941 & 0.127 & 0.150 & 0.130 & 0.457 & 0.230 & 0.427 \\
\hline 1994 & Spain & -2.388 & -2.164 & -1.983 & 0.260 & 0.157 & 0.131 & 0.305 & 0.246 & 0.472 \\
\hline 1995 & Spain & -2.956 & -2.348 & -2.207 & 0.262 & 0.164 & 0.133 & 0.300 & 0.259 & 0.420 \\
\hline 1996 & Spain & -2.828 & -2.522 & -2.350 & 0.125 & 0.170 & 0.135 & 0.359 & 0.267 & 0.421 \\
\hline 1997 & Spain & -3.200 & -2.674 & -2.254 & 0.030 & 0.174 & 0.132 & 0.385 & 0.272 & 0.460 \\
\hline 1998 & Spain & -3.025 & -2.796 & -2.284 & 0.134 & 0.175 & 0.130 & 0.289 & 0.272 & 0.466 \\
\hline 1999 & Spain & -2.886 & -2.890 & -2.259 & 0.137 & 0.174 & 0.129 & 0.346 & 0.269 & 0.464 \\
\hline 2000 & Spain & -5.457 & -2.962 & -2.255 & 0.213 & 0.171 & 0.129 & -0.004 & 0.265 & 0.458 \\
\hline 2001 & Spain & -6.129 & -3.018 & -2.261 & 0.279 & 0.167 & 0.129 & -0.002 & 0.258 & 0.450 \\
\hline 2002 & Spain & & -3.064 & -2.257 & & 0.161 & 0.128 & & 0.250 & 0.445 \\
\hline 2003 & Spain & & -3.104 & -2.253 & & 0.154 & 0.128 & & 0.242 & 0.441 \\
\hline 2004 & Spain & & -3.140 & -2.249 & & 0.146 & 0.128 & & 0.232 & 0.439 \\
\hline 2005 & Spain & & -3.172 & -2.244 & & 0.137 & 0.128 & & 0.222 & 0.437 \\
\hline$\overline{1976}$ & Finland & & $=-1.609$ & -1.340 & & 0.067 & 0.104 & & "0.560 & 0.410 \\
\hline 1977 & Finland & & -1.559 & -1.354 & & 0.071 & 0.104 & & 0.493 & 0.421 \\
\hline 1978 & Finland & & -1.509 & -1.374 & & 0.073 & 0.105 & & 0.424 & 0.424 \\
\hline 1979 & Finland & & -1.464 & -1.384 & & 0.074 & 0.106 & & 0.357 & 0.401 \\
\hline 1980 & Finland & & -1.427 & -1.394 & & 0.075 & 0.107 & & 0.298 & 0.377 \\
\hline 1981 & Finland & -1.338 & -1.402 & -1.408 & 0.125 & 0.077 & 0.107 & 0.695 & 0.248 & 0.353 \\
\hline 1982 & Finland & -0.706 & -1.396 & -1.417 & 0.257 & 0.080 & 0.107 & 0.641 & 0.211 & 0.323 \\
\hline 1983 & Finland & -0.289 & -1.415 & -1.424 & 0.308 & 0.086 & 0.107 & 0.444 & 0.186 & 0.292 \\
\hline 1984 & Finland & 0.095 & -1.462 & -1.422 & 0.274 & 0.095 & 0.108 & -0.004 & 0.175 & 0.262 \\
\hline 1985 & Finland & 0.144 & -1.538 & -1.448 & 0.235 & 0.107 & 0.108 & 0.005 & 0.178 & 0.234 \\
\hline 1986 & Finland & 0.418 & -1.635 & -1.474 & 0.263 & 0.121 & 0.107 & 0.071 & 0.191 & 0.207 \\
\hline 1987 & Finland & -0.731 & -1.739 & -1.505 & 0.312 & 0.133 & 0.107 & 0.021 & 0.210 & 0.174 \\
\hline 1988 & Finland & -1.668 & -1.830 & -1.547 & 0.191 & 0.142 & 0.106 & 0.052 & 0.229 & 0.150 \\
\hline 1989 & Finland & -1.746 & -1.892 & -1.642 & 0.212 & 0.145 & 0.104 & 0.070 & 0.241 & 0.170 \\
\hline 1990 & Finland & -3.217 & -1.920 & -1.819 & 0.342 & 0.143 & 0.113 & 0.507 & 0.244 & 0.241 \\
\hline 1991 & Finland & -3.296 & -1.918 & -1.967 & 0.332 & 0.137 & 0.116 & 0.424 & 0.239 & 0.258 \\
\hline 1992 & Finland & -2.594 & -1.893 & -2.284 & 0.206 & 0.129 & 0.117 & 0.372 & 0.228 & 0.370 \\
\hline 1993 & Finland & -1.934 & -1.854 & -1.738 & 0.168 & 0.119 & 0.114 & 0.269 & 0.212 & 0.342 \\
\hline 1994 & Finland & -1.779 & -1.804 & -1.411 & 0.135 & 0.109 & 0.097 & 0.275 & 0.193 & 0.186 \\
\hline 1995 & Finland & -1.973 & -1.748 & -1.610 & 0.105 & 0.099 & 0.093 & 0.218 & 0.174 & 0.073 \\
\hline 1996 & Finland & -1.846 & -1.684 & -1.389 & 0.092 & 0.089 & 0.090 & 0.184 & 0.155 & 0.043 \\
\hline 1997 & Finland & -1.429 & -1.613 & -1.367 & 0.070 & 0.079 & 0.088 & 0.075 & 0.137 & 0.060 \\
\hline 1998 & Finland & -1.792 & -1.534 & -1.221 & 0.066 & 0.070 & 0.089 & 0.050 & 0.121 & 0.042 \\
\hline 1999 & Finland & -1.571 & -1.447 & -1.026 & 0.014 & 0.062 & 0.089 & -0.009 & 0.106 & 0.038 \\
\hline 2000 & Finland & -1.961 & -1.355 & -0.942 & 0.017 & 0.054 & 0.088 & -0.104 & 0.093 & 0.024 \\
\hline 2001 & Finland & -0.511 & -1.261 & -0.907 & -0.073 & 0.047 & 0.088 & -0.241 & 0.082 & 0.025 \\
\hline 2002 & Finland & & -1.168 & -0.887 & & 0.040 & 0.089 & & 0.072 & 0.029 \\
\hline 2003 & Finland & & -1.077 & -0.876 & & 0.034 & 0.090 & & 0.063 & 0.047 \\
\hline 2004 & Finland & & -0.988 & -0.859 & & 0.029 & 0.090 & & 0.054 & 0.067 \\
\hline 2005 & Finland & & -0.897 & -0.843 & & 0.025 & 0.090 & & 0.045 & 0.069 \\
\hline
\end{tabular}

Note: the table reports the $a_{1 i t}$ coefficients, i.e. the coefficients on the output gap composite variable (see equation 1), using various estimation techniques. 10YRW stands for the 10-years rolling window OLS method, WRW for the Gaussian-weighted rolling window OLS method and $\operatorname{AR}(1)$ for the $A R(1) M C M C$ method.

Source: OECD Economic Outlook. 


\begin{tabular}{|c|c|c|c|c|c|c|c|c|c|c|}
\hline \multirow[b]{2}{*}{ Year } & \multirow[b]{2}{*}{ Country } & \multicolumn{3}{|c|}{ Procyclicality of public debt } & \multicolumn{3}{|c|}{ Procyclicality of public investment } & \multicolumn{3}{|c|}{ Procyclicality of public consumption } \\
\hline & & 10YRW & WRW & $\mathrm{AR}(1)$ & $\overline{10 Y R W}$ & WRW & $\mathrm{AR}(1)$ & 10YRV & WRW & $\mathrm{AR}(1)$ \\
\hline 1978 & France & & 0.708 & 0.491 & & 0.015 & 0.041 & & 0.011 & 0.145 \\
\hline 1979 & France & & 0.615 & 0.477 & & 0.020 & 0.042 & & 0.064 & 0.137 \\
\hline 1980 & France & & 0.536 & 0.453 & & 0.023 & 0.042 & & 0.108 & 0.146 \\
\hline 1981 & France & & 0.466 & 0.424 & & 0.023 & 0.043 & & 0.141 & 0.150 \\
\hline 1982 & France & & 0.400 & 0.317 & & 0.023 & 0.044 & & 0.162 & 0.169 \\
\hline 1983 & France & 2.491 & 0.328 & 0.291 & -0.041 & 0.022 & 0.046 & -0.767 & 0.171 & 0.207 \\
\hline 1984 & France & 0.437 & 0.244 & 0.220 & 0.174 & 0.021 & 0.046 & 0.085 & 0.165 & 0.224 \\
\hline 1985 & France & 0.170 & 0.147 & 0.123 & 0.082 & 0.019 & 0.045 & 0.137 & 0.143 & 0.258 \\
\hline 1986 & France & -0.184 & 0.043 & -0.047 & 0.027 & 0.017 & 0.047 & 0.121 & 0.110 & 0.229 \\
\hline 1987 & France & -0.027 & -0.060 & -0.237 & 0.031 & 0.014 & 0.047 & 0.122 & 0.071 & 0.205 \\
\hline 1988 & France & -0.499 & -0.153 & -0.357 & -0.036 & 0.012 & 0.048 & 0.113 & 0.032 & 0.182 \\
\hline 1989 & France & -0.587 & -0.236 & -0.484 & 0.020 & 0.012 & 0.049 & -0.022 & 0.000 & 0.161 \\
\hline 1990 & France & -0.390 & -0.316 & -0.631 & 0.002 & 0.013 & 0.051 & 0.026 & -0.021 & 0.142 \\
\hline 1991 & France & -0.572 & -0.402 & -0.725 & 0.024 & 0.018 & 0.053 & -0.017 & -0.029 & 0.136 \\
\hline 1992 & France & -0.900 & -0.504 & -0.794 & 0.022 & 0.027 & 0.055 & -0.026 & -0.024 & 0.127 \\
\hline 1993 & France & -0.395 & -0.624 & -0.870 & -0.118 & 0.040 & 0.058 & -0.221 & -0.008 & 0.119 \\
\hline 1994 & France & 1.019 & -0.758 & -0.942 & 0.085 & 0.056 & 0.058 & -0.426 & 0.016 & 0.160 \\
\hline 1995 & France & -2.804 & -0.893 & -1.067 & 0.173 & 0.073 & 0.059 & 0.013 & 0.045 & 0.161 \\
\hline 1996 & France & -1.643 & -1.016 & -1.017 & 0.206 & 0.088 & 0.059 & 0.114 & 0.074 & 0.122 \\
\hline 1997 & France & -1.452 & -1.121 & -1.032 & 0.139 & 0.100 & 0.060 & 0.112 & 0.100 & 0.111 \\
\hline 1998 & France & -0.852 & -1.207 & -1.116 & 0.113 & 0.108 & 0.058 & 0.052 & 0.120 & 0.146 \\
\hline 1999 & France & -1.134 & -1.281 & -1.054 & 0.096 & 0.110 & 0.057 & 0.134 & 0.135 & 0.158 \\
\hline 2000 & France & -1.431 & -1.349 & -1.107 & 0.099 & 0.109 & 0.056 & 0.138 & 0.146 & 0.169 \\
\hline 2001 & France & -1.226 & -1.417 & -1.170 & 0.101 & 0.105 & 0.055 & 0.091 & 0.154 & 0.178 \\
\hline 2002 & France & & -1.488 & -1.221 & & 0.099 & 0.054 & & 0.160 & 0.191 \\
\hline 2003 & France & & -1.559 & -1.271 & & 0.093 & 0.053 & & 0.165 & 0.206 \\
\hline 2004 & France & & -1.625 & -1.338 & & 0.086 & 0.053 & & 0.171 & 0.199 \\
\hline 2005 & France & & -1.679 & -1.374 & & 0.080 & 0.053 & & 0.177 & 0.200 \\
\hline$\overline{1971}$ & " United Kingdom & & $\begin{array}{c}-0.321 \\
\end{array}$ & $\begin{array}{c}-0.749 \\
\end{array}$ & & 0.252 & 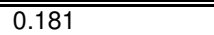 & & 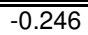 & $\begin{array}{l}-0.595 \\
\end{array}$ \\
\hline 1972 & United Kingdom & & -0.174 & -0.730 & & 0.238 & 0.181 & & -0.170 & -0.591 \\
\hline 1973 & United Kingdom & & -0.023 & -0.720 & & 0.223 & 0.181 & & -0.090 & -0.588 \\
\hline 1974 & United Kingdom & & 0.123 & -0.737 & & 0.208 & 0.177 & & -0.010 & -0.609 \\
\hline 1975 & United Kingdom & & 0.254 & -0.752 & & 0.192 & 0.173 & & 0.064 & -0.629 \\
\hline 1976 & United Kingdom & -0.951 & 0.357 & -0.687 & 0.255 & 0.177 & 0.171 & -0.584 & 0.126 & -0.481 \\
\hline 1977 & United Kingdom & 0.451 & 0.421 & -0.610 & 0.271 & 0.162 & 0.168 & 0.017 & 0.172 & -0.386 \\
\hline 1978 & United Kingdom & 1.665 & 0.438 & -0.509 & 0.222 & 0.148 & 0.162 & 0.792 & 0.197 & -0.351 \\
\hline 1979 & United Kingdom & 1.749 & 0.402 & -0.407 & 0.214 & 0.135 & 0.157 & 0.887 & 0.195 & -0.317 \\
\hline 1980 & United Kingdom & 1.763 & 0.313 & -0.309 & 0.204 & 0.122 & 0.151 & 0.891 & 0.167 & -0.286 \\
\hline 1981 & United Kingdom & 1.926 & 0.182 & -0.076 & 0.133 & 0.110 & 0.148 & 0.437 & 0.116 & -0.081 \\
\hline 1982 & United Kingdom & 2.063 & 0.028 & 0.003 & 0.176 & 0.098 & 0.139 & -0.063 & 0.050 & 0.037 \\
\hline 1983 & United Kingdom & 1.822 & -0.125 & -0.226 & 0.109 & 0.087 & 0.131 & -0.107 & -0.022 & 0.072 \\
\hline 1984 & United Kingdom & 1.561 & -0.262 & -0.617 & 0.062 & 0.077 & 0.131 & -0.163 & -0.089 & 0.116 \\
\hline 1985 & United Kingdom & 0.652 & -0.373 & -0.617 & 0.126 & 0.067 & 0.132 & -0.363 & -0.143 & 0.122 \\
\hline 1986 & United Kingdom & 0.275 & -0.463 & -0.781 & 0.090 & 0.059 & 0.133 & -0.140 & -0.179 & 0.104 \\
\hline 1987 & United Kingdom & 0.266 & -0.548 & -0.987 & 0.037 & 0.054 & 0.133 & -0.066 & -0.194 & 0.091 \\
\hline 1988 & United Kingdom & 0.393 & -0.653 & -1.319 & -0.083 & 0.053 & 0.135 & -0.017 & -0.186 & 0.084 \\
\hline 1989 & United Kingdom & -0.657 & -0.805 & -1.627 & 0.068 & 0.057 & 0.143 & 0.258 & -0.152 & 0.089 \\
\hline 1990 & United Kingdom & -2.160 & -1.020 & -1.882 & 0.127 & 0.066 & 0.146 & 0.175 & -0.095 & 0.117 \\
\hline 1991 & United Kingdom & -2.509 & -1.291 & -2.080 & 0.153 & 0.081 & 0.148 & 0.254 & -0.023 & 0.132 \\
\hline 1992 & United Kingdom & -2.147 & -1.591 & -2.343 & 0.279 & 0.098 & 0.149 & 0.330 & 0.055 & 0.175 \\
\hline 1993 & United Kingdom & -2.809 & -1.887 & -2.608 & 0.267 & 0.116 & 0.151 & 0.396 & 0.128 & 0.238 \\
\hline 1994 & United Kingdom & -3.360 & -2.153 & -2.453 & 0.270 & 0.133 & 0.154 & 0.342 & 0.195 & 0.219 \\
\hline 1995 & United Kingdom & -3.402 & -2.377 & -2.541 & 0.234 & 0.148 & 0.157 & 0.352 & 0.254 & 0.206 \\
\hline 1996 & United Kingdom & -4.601 & -2.553 & -2.507 & 0.077 & 0.163 & 0.160 & 0.741 & 0.310 & 0.190 \\
\hline 1997 & United Kingdom & -4.421 & -2.681 & -2.531 & 0.239 & 0.178 & 0.161 & 0.505 & 0.362 & 0.184 \\
\hline 1998 & United Kingdom & -5.003 & -2.767 & -2.536 & 0.184 & 0.192 & 0.161 & 0.738 & 0.409 & 0.163 \\
\hline 1999 & United Kingdom & -5.514 & -2.826 & -2.536 & 0.267 & 0.207 & 0.161 & 0.518 & 0.448 & 0.141 \\
\hline 2000 & United Kingdom & -7.900 & -2.876 & -2.538 & 0.455 & 0.222 & 0.162 & 0.444 & 0.474 & 0.120 \\
\hline 2001 & United Kingdom & -5.269 & -2.932 & -2.598 & 0.574 & 0.236 & 0.162 & 0.159 & 0.484 & 0.102 \\
\hline 2002 & United Kingdom & & -3.000 & -2.613 & & 0.250 & 0.162 & & 0.474 & 0.088 \\
\hline 2003 & United Kingdom & & -3.073 & -2.627 & & 0.266 & 0.161 & & 0.445 & 0.079 \\
\hline 2004 & United Kingdom & & -3.136 & -2.625 & & 0.281 & 0.162 & & 0.395 & 0.078 \\
\hline 2005 & United Kingdom & & -3.167 & -2.622 & & 0.298 & 0.162 & & 0.324 & 0.077 \\
\hline
\end{tabular}

Note: the table reports the $a_{1 i t}$ coefficients, i.e. the coefficients on the output gap composite variable (see equation 1), using various estimation techniques. 10YRW stands for the 10-years rolling window OLS method, WRW for the Gaussian-weighted rolling window OLS method and $\mathrm{AR}(1)$ for the $\mathrm{AR}(1) \mathrm{MCMC}$ method.

Source: OECD Economic Outlook. 


\begin{tabular}{|c|c|c|c|c|c|c|c|c|c|c|}
\hline \multirow{2}{*}{\multicolumn{2}{|c|}{ Year Country }} & \multicolumn{3}{|c|}{ Procyclicality of public debt } & \multicolumn{3}{|c|}{ Procyclicality of public investment } & \multicolumn{3}{|c|}{ Procyclicality of public consumption } \\
\hline & & 10YRW & WRW & $\mathrm{AR}(1)$ & 10YRV & WRW & $\mathrm{AR}(1)$ & $10 \mathrm{YR}$ & WRW & $\mathrm{AR}(1)$ \\
\hline 1975 & Greece & & -0.109 & & & & & & & \\
\hline 1976 & Greece & & -0.186 & & & & & & & \\
\hline 1977 & Greece & & -0.269 & & & & & & & \\
\hline 1978 & Greece & & -0.353 & & & & & & & \\
\hline 1979 & Greece & & -0.434 & & & & & & & \\
\hline 1980 & Greece & -0.167 & -0.505 & & & & & & & \\
\hline 1981 & Greece & -0.404 & -0.563 & & & & & & & \\
\hline 1982 & Greece & -0.851 & -0.601 & & & & & & & \\
\hline 1983 & Greece & -1.101 & -0.615 & & & & & & & \\
\hline 1984 & Greece & -0.719 & -0.598 & & & & & & & \\
\hline 1985 & Greece & -0.578 & -0.547 & & & & & & & \\
\hline 1986 & Greece & 0.058 & -0.464 & & & & & & & \\
\hline 1987 & Greece & 0.359 & -0.365 & & & & & & & \\
\hline 1988 & Greece & 1.565 & -0.277 & & & & & & & \\
\hline 1989 & Greece & -1.524 & -0.232 & & & & & & & \\
\hline 1990 & Greece & -0.215 & -0.256 & & & & & & & \\
\hline 1991 & Greece & -0.211 & -0.354 & & & & & & & \\
\hline 1992 & Greece & -0.920 & -0.507 & & & & & & & \\
\hline 1993 & Greece & -4.638 & -0.675 & & & & & & & \\
\hline 1994 & Greece & -7.648 & -0.815 & & & & & & & \\
\hline 1995 & Greece & -9.259 & -0.891 & & & & & & & \\
\hline 1996 & Greece & -4.887 & -0.892 & & & & & & & \\
\hline 1997 & Greece & -3.114 & -0.828 & & & & & & & \\
\hline 1998 & Greece & 1.453 & -0.721 & & & & & & & \\
\hline 1999 & Greece & 0.565 & -0.591 & & & & & & & \\
\hline 2000 & Greece & 0.426 & -0.458 & & & & & & & \\
\hline 2001 & Greece & 0.050 & -0.333 & & & & & & & \\
\hline 2002 & Greece & & -0.225 & & & & & & & \\
\hline 2003 & Greece & & -0.140 & & & & & & & \\
\hline 2004 & Greece & & -0.077 & & & & & & & \\
\hline 2005 & Greece & & -0.035 & & & & & & & \\
\hline 1978 & Ireland & & -3.113 & -0.142 & & 0.298 & 0.284 & & 0.434 & 0.715 \\
\hline 1979 & Ireland & & -3.136 & -0.128 & & 0.280 & 0.286 & & 0.406 & 0.756 \\
\hline 1980 & Ireland & & -3.135 & -0.358 & & 0.263 & 0.285 & & 0.383 & 0.771 \\
\hline 1981 & Ireland & & -3.104 & -0.462 & & 0.246 & 0.279 & & 0.365 & 0.678 \\
\hline 1982 & Ireland & & -3.038 & -0.763 & & 0.230 & 0.273 & & 0.353 & 0.598 \\
\hline 1983 & Ireland & -3.386 & -2.927 & -1.073 & 0.288 & 0.214 & 0.267 & 0.309 & 0.346 & 0.514 \\
\hline 1984 & Ireland & -3.406 & -2.764 & -1.059 & 0.215 & 0.197 & 0.262 & 0.235 & 0.346 & 0.498 \\
\hline 1985 & Ireland & -3.531 & -2.545 & -1.115 & 0.221 & 0.181 & 0.255 & 0.253 & 0.353 & 0.465 \\
\hline 1986 & Ireland & -3.047 & -2.277 & -1.279 & 0.185 & 0.166 & 0.250 & 0.321 & 0.365 & 0.410 \\
\hline 1987 & Ireland & -3.345 & -1.982 & -1.043 & 0.193 & 0.151 & 0.250 & 0.339 & 0.381 & 0.512 \\
\hline 1988 & Ireland & -3.404 & -1.702 & -0.971 & 0.213 & 0.138 & 0.245 & 0.365 & 0.396 & 0.554 \\
\hline 1989 & Ireland & -2.780 & -1.475 & -0.959 & 0.115 & 0.124 & 0.238 & 0.337 & 0.403 & 0.539 \\
\hline 1990 & Ireland & -1.868 & -1.311 & -0.947 & 0.081 & 0.110 & 0.230 & 0.326 & 0.400 & 0.523 \\
\hline 1991 & Ireland & -1.953 & -1.183 & -0.917 & 0.082 & 0.096 & 0.223 & 0.357 & 0.390 & 0.473 \\
\hline 1992 & Ireland & -0.995 & -1.059 & -0.894 & 0.097 & 0.084 & 0.217 & 0.470 & 0.377 & 0.424 \\
\hline 1993 & Ireland & -0.794 & -0.925 & -0.967 & 0.048 & 0.078 & 0.210 & 0.419 & 0.366 & 0.379 \\
\hline 1994 & Ireland & -0.795 & -0.784 & -0.633 & 0.037 & 0.078 & 0.208 & 0.399 & 0.357 & 0.368 \\
\hline 1995 & Ireland & -0.108 & -0.649 & -0.575 & 0.052 & 0.087 & 0.209 & 0.341 & 0.350 & 0.388 \\
\hline 1996 & Ireland & -0.859 & -0.531 & -0.482 & -0.006 & 0.105 & 0.210 & 0.282 & 0.346 & 0.396 \\
\hline 1997 & Ireland & -2.475 & -0.439 & -0.449 & -0.068 & 0.132 & 0.212 & 0.226 & 0.342 & 0.389 \\
\hline 1998 & Ireland & -1.527 & -0.378 & -0.439 & 0.177 & 0.164 & 0.214 & 0.122 & 0.339 & 0.379 \\
\hline 1999 & Ireland & 0.162 & -0.348 & -0.418 & 0.479 & 0.197 & 0.216 & 0.406 & 0.335 & 0.366 \\
\hline 2000 & Ireland & 0.010 & -0.343 & -0.510 & 0.383 & 0.227 & 0.216 & 0.423 & 0.332 & 0.372 \\
\hline 2001 & Ireland & -0.326 & -0.354 & -0.407 & 0.309 & 0.251 & 0.215 & 0.339 & 0.328 & 0.405 \\
\hline 2002 & Ireland & & -0.373 & -0.408 & & 0.267 & 0.208 & & 0.325 & 0.380 \\
\hline 2003 & Ireland & & -0.396 & -0.414 & & 0.277 & 0.206 & & 0.322 & 0.371 \\
\hline 2004 & Ireland & & -0.419 & -0.416 & & 0.281 & 0.206 & & 0.319 & 0.373 \\
\hline 2005 & Ireland & & -0.440 & -0.411 & & 0.281 & 0.206 & & 0.318 & 0.377 \\
\hline
\end{tabular}

Note: the table reports the $a_{1 i t}$ coefficients, i.e. the coefficients on the output gap composite variable (see equation 1), using various estimation techniques. 10YRW stands for the 10-years rolling window OLS method, WRW for the Gaussian-weighted rolling window OLS method and $\operatorname{AR}(1)$ for the $A R(1) M C M C$ method.

Source: OECD Economic Outlook. 


\begin{tabular}{|c|c|c|c|c|c|c|c|c|c|c|}
\hline \multirow[b]{2}{*}{ Year } & \multirow[b]{2}{*}{ Country } & \multicolumn{3}{|c|}{ Procyclicality of public debt } & \multicolumn{3}{|c|}{ Procyclicality of public investment } & \multicolumn{3}{|c|}{ Procyclicality of public consumption } \\
\hline & & 10YRW & WRW & $\mathrm{AR}(1)$ & 10YRW & WRW & $\mathrm{AR}(1)$ & 10YRW & WRW & $\mathrm{AR}(1)$ \\
\hline 1981 & Iceland & & -1.908 & -1.588 & & 0.023 & 0.110 & & -0.310 & -0.392 \\
\hline 1982 & Iceland & & -1.864 & -1.442 & & 0.029 & 0.109 & & -0.258 & -0.370 \\
\hline 1983 & Iceland & & -1.815 & -1.479 & & 0.036 & 0.107 & & -0.201 & -0.367 \\
\hline 1984 & Iceland & & -1.759 & -1.445 & & 0.045 & 0.109 & & -0.136 & -0.201 \\
\hline 1985 & Iceland & & -1.697 & -1.364 & & 0.054 & 0.109 & & -0.061 & -0.163 \\
\hline 1986 & Iceland & -1.773 & -1.630 & -1.309 & 0.055 & 0.065 & 0.112 & -0.164 & 0.020 & -0.026 \\
\hline 1987 & Iceland & -1.394 & -1.565 & -1.234 & 0.043 & 0.075 & 0.116 & -0.160 & 0.104 & 0.117 \\
\hline 1988 & Iceland & -1.710 & -1.507 & -1.207 & 0.064 & 0.084 & 0.119 & -0.176 & 0.183 & 0.160 \\
\hline 1989 & Iceland & -1.545 & -1.464 & -1.181 & 0.167 & 0.092 & 0.121 & 0.201 & 0.252 & 0.205 \\
\hline 1990 & Iceland & -1.109 & -1.437 & -1.161 & 0.092 & 0.098 & 0.123 & 0.279 & 0.304 & 0.251 \\
\hline 1991 & Iceland & -0.786 & -1.428 & -1.146 & 0.058 & 0.101 & 0.125 & 0.628 & 0.336 & 0.294 \\
\hline 1992 & Iceland & -1.123 & -1.433 & -1.248 & 0.133 & 0.102 & 0.127 & 0.610 & 0.351 & 0.333 \\
\hline 1993 & Iceland & -1.384 & -1.444 & -1.406 & 0.146 & 0.101 & 0.124 & 0.415 & 0.351 & 0.231 \\
\hline 1994 & Iceland & -1.587 & -1.454 & -1.425 & 0.199 & 0.097 & 0.133 & 0.367 & 0.339 & 0.197 \\
\hline 1995 & Iceland & -1.731 & -1.457 & -1.336 & 0.169 & 0.093 & 0.142 & 0.344 & 0.320 & 0.144 \\
\hline 1996 & Iceland & -1.615 & -1.448 & -1.169 & 0.079 & 0.088 & 0.139 & 0.286 & 0.297 & 0.122 \\
\hline 1997 & Iceland & -1.272 & -1.424 & -1.001 & 0.100 & 0.085 & 0.140 & 0.297 & 0.276 & 0.103 \\
\hline 1998 & Iceland & -1.667 & -1.385 & -0.828 & 0.076 & 0.085 & 0.140 & 0.240 & 0.260 & 0.078 \\
\hline 1999 & Iceland & -2.662 & -1.332 & -0.655 & 0.323 & 0.089 & 0.137 & 0.260 & 0.253 & 0.020 \\
\hline 2000 & Iceland & -0.927 & -1.260 & -0.377 & 0.510 & 0.101 & 0.134 & 0.413 & 0.256 & -0.040 \\
\hline 2001 & Iceland & 0.596 & -1.162 & -0.005 & 0.408 & 0.121 & 0.137 & 0.552 & 0.269 & -0.074 \\
\hline 2002 & Iceland & & -1.026 & -0.045 & & 0.149 & 0.135 & & 0.291 & -0.094 \\
\hline 2003 & Iceland & & -0.844 & -0.081 & & 0.184 & 0.134 & & 0.319 & -0.118 \\
\hline 2004 & Iceland & & -0.612 & -0.092 & & 0.224 & 0.133 & & 0.351 & -0.137 \\
\hline 2005 & Iceland & & -0.334 & -0.086 & & 0.267 & 0.132 & & 0.386 & -0.138 \\
\hline 1965 & Italy & & 1.193 & 0.280 & & 0.148 & 0.103 & & 0.066 & -0.164 \\
\hline 1966 & Italy & & 1.162 & 0.289 & & 0.139 & 0.102 & & 0.057 & -0.125 \\
\hline 1967 & Italy & & 1.141 & 0.233 & & 0.129 & 0.101 & & 0.054 & -0.123 \\
\hline 1968 & Italy & & 1.125 & 0.176 & & 0.119 & 0.100 & & 0.059 & -0.121 \\
\hline 1969 & Italy & & 1.107 & 0.104 & & 0.110 & 0.099 & & 0.074 & -0.117 \\
\hline 1970 & Italy & 0.282 & 1.078 & 0.062 & 0.170 & 0.102 & 0.099 & -0.028 & 0.100 & -0.098 \\
\hline 1971 & Italy & 1.538 & 1.026 & 0.165 & 0.027 & 0.095 & 0.097 & 0.311 & 0.137 & -0.020 \\
\hline 1972 & Italy & 1.753 & 0.940 & 0.251 & 0.066 & 0.090 & 0.096 & 0.287 & 0.183 & 0.010 \\
\hline 1973 & Italy & 1.363 & 0.814 & 0.337 & 0.015 & 0.087 & 0.095 & -0.308 & 0.233 & 0.041 \\
\hline 1974 & Italy & 0.928 & 0.647 & 0.368 & -0.050 & 0.086 & 0.095 & -0.262 & 0.279 & 0.084 \\
\hline 1975 & Italy & -0.661 & 0.451 & 0.282 & -0.036 & 0.084 & 0.094 & -0.026 & 0.313 & 0.113 \\
\hline 1976 & Italy & -0.335 & 0.243 & 0.215 & -0.026 & 0.082 & 0.095 & 0.124 & 0.330 & 0.131 \\
\hline 1977 & Italy & -0.373 & 0.049 & 0.152 & 0.031 & 0.080 & 0.096 & 0.212 & 0.329 & 0.153 \\
\hline 1978 & Italy & -0.323 & -0.111 & 0.092 & 0.046 & 0.076 & 0.098 & 0.265 & 0.316 & 0.181 \\
\hline 1979 & Italy & -0.247 & -0.224 & 0.027 & 0.091 & 0.074 & 0.099 & 0.342 & 0.298 & 0.210 \\
\hline 1980 & Italy & -0.404 & -0.291 & 0.018 & 0.087 & 0.072 & 0.102 & 0.458 & 0.284 & 0.239 \\
\hline 1981 & Italy & -0.345 & -0.317 & 0.037 & 0.154 & 0.072 & 0.103 & 0.373 & 0.275 & 0.291 \\
\hline 1982 & Italy & -0.450 & -0.309 & 0.084 & 0.120 & 0.073 & 0.102 & 0.248 & 0.273 & 0.293 \\
\hline 1983 & Italy & -0.278 & -0.268 & 0.140 & 0.019 & 0.075 & 0.101 & 0.296 & 0.277 & 0.283 \\
\hline 1984 & Italy & -0.470 & -0.191 & 0.162 & 0.054 & 0.078 & 0.100 & 0.367 & 0.284 & 0.308 \\
\hline 1985 & Italy & -0.735 & -0.073 & 0.183 & 0.104 & 0.081 & 0.099 & 0.235 & 0.293 & 0.304 \\
\hline 1986 & Italy & -0.269 & 0.084 & 0.295 & 0.144 & 0.083 & 0.099 & 0.456 & 0.302 & 0.317 \\
\hline 1987 & Italy & 0.283 & 0.273 & 0.365 & 0.025 & 0.086 & 0.099 & 0.262 & 0.311 & 0.279 \\
\hline 1988 & Italy & 0.271 & 0.476 & 0.462 & 0.078 & 0.088 & 0.100 & 0.458 & 0.317 & 0.269 \\
\hline 1989 & Italy & 1.928 & 0.666 & 0.566 & 0.091 & 0.091 & 0.100 & 0.316 & 0.321 & 0.253 \\
\hline 1990 & Italy & 1.249 & 0.818 & 0.753 & 0.073 & 0.095 & 0.101 & 0.344 & 0.324 & 0.291 \\
\hline 1991 & Italy & 1.771 & 0.910 & 0.814 & 0.130 & 0.101 & 0.101 & 0.314 & 0.325 & 0.286 \\
\hline 1992 & Italy & 2.100 & 0.929 & 0.897 & 0.184 & 0.107 & 0.102 & 0.123 & 0.327 & 0.278 \\
\hline 1993 & Italy & 1.297 & 0.866 & 1.017 & 0.290 & 0.113 & 0.102 & 0.392 & 0.330 & 0.257 \\
\hline 1994 & Italy & 0.293 & 0.722 & 0.758 & 0.362 & 0.118 & 0.100 & 0.569 & 0.334 & 0.261 \\
\hline 1995 & Italy & -1.579 & 0.501 & 0.725 & 0.345 & 0.121 & 0.097 & 0.458 & 0.341 & 0.248 \\
\hline 1996 & Italy & -1.670 & 0.220 & 0.676 & 0.356 & 0.120 & 0.094 & 0.526 & 0.350 & 0.208 \\
\hline 1997 & Italy & -2.088 & -0.093 & 0.679 & 0.317 & 0.115 & 0.091 & 0.518 & 0.361 & 0.214 \\
\hline 1998 & Italy & -2.217 & -0.399 & 0.624 & 0.352 & 0.105 & 0.089 & 0.553 & 0.374 & 0.229 \\
\hline 1999 & Italy & -3.625 & -0.661 & 0.620 & -0.011 & 0.092 & 0.088 & 0.417 & 0.385 & 0.235 \\
\hline 2000 & Italy & -1.371 & -0.861 & 0.555 & -0.035 & 0.075 & 0.087 & 0.259 & 0.392 & 0.240 \\
\hline 2001 & Italy & -1.430 & -1.001 & 0.489 & -0.026 & 0.058 & 0.085 & 0.340 & 0.394 & 0.243 \\
\hline 2002 & Italy & & -1.100 & 0.430 & & 0.041 & 0.084 & & 0.391 & 0.242 \\
\hline 2003 & Italy & & -1.171 & 0.374 & & 0.026 & 0.081 & & 0.384 & 0.231 \\
\hline 2004 & Italy & & -1.224 & 0.322 & & 0.011 & 0.083 & & 0.376 & 0.245 \\
\hline 2005 & Italy & & -1.262 & 0.296 & & -0.002 & 0.083 & & 0.367 & 0.271 \\
\hline
\end{tabular}

Note: the table reports the $a_{1 i t}$ coefficients, i.e. the coefficients on the output gap composite variable (see equation 1), using various estimation techniques. 10YRW stands for the 10-years rolling window OLS method, WRW for the Gaussian-weighted rolling window OLS method and $A R(1)$ for the $A R(1) M C M C$ method.

Source: OECD Economic Outlook. 


\begin{tabular}{|c|c|c|c|c|c|c|c|c|c|c|}
\hline \multirow[b]{2}{*}{ Year } & \multirow[b]{2}{*}{ Country } & \multicolumn{3}{|c|}{ Procyclicality of public debt } & \multicolumn{3}{|c|}{ Procyclicality of public investment } & \multicolumn{3}{|c|}{ Procyclicality of public consumption } \\
\hline & & 10YRW & WRW & $\mathrm{AR}(1)$ & 10YRW & WRW & $\mathrm{AR}(1)$ & 10YRW & WRW & $\mathrm{AR}(1)$ \\
\hline 1971 & Japan & & -1.564 & -1.220 & & 0.399 & 0.061 & & -0.368 & -0.227 \\
\hline 1972 & Japan & & -1.552 & -1.242 & & 0.399 & 0.061 & & -0.353 & -0.218 \\
\hline 1973 & Japan & & -1.539 & -1.280 & & 0.399 & 0.062 & & -0.334 & -0.207 \\
\hline 1974 & Japan & & -1.524 & -1.287 & & 0.399 & 0.060 & & -0.313 & -0.217 \\
\hline 1975 & Japan & & -1.502 & -1.336 & & 0.397 & 0.057 & & -0.289 & -0.187 \\
\hline 1976 & Japan & -1.214 & -1.475 & -1.427 & 0.434 & 0.394 & 0.054 & -0.411 & -0.261 & -0.135 \\
\hline 1977 & Japan & -0.512 & -1.451 & -1.449 & 0.421 & 0.388 & 0.049 & -0.357 & -0.231 & -0.125 \\
\hline 1978 & Japan & -0.459 & -1.448 & -1.466 & 0.418 & 0.377 & 0.046 & -0.291 & -0.196 & -0.112 \\
\hline 1979 & Japan & 2.733 & -1.487 & -1.452 & 0.448 & 0.360 & 0.043 & -0.512 & -0.158 & -0.101 \\
\hline 1980 & Japan & 3.466 & -1.589 & -1.435 & 0.511 & 0.336 & 0.040 & -0.672 & -0.117 & -0.085 \\
\hline 1981 & Japan & 0.233 & -1.760 & -1.436 & 0.503 & 0.305 & 0.038 & -0.058 & -0.078 & -0.076 \\
\hline 1982 & Japan & -0.367 & -1.982 & -1.439 & 0.271 & 0.272 & 0.036 & -0.080 & -0.043 & -0.066 \\
\hline 1983 & Japan & -2.771 & -2.232 & -1.444 & -0.063 & 0.237 & 0.034 & 0.083 & -0.016 & -0.055 \\
\hline 1984 & Japan & -2.634 & -2.490 & -1.444 & 0.366 & 0.202 & 0.031 & -0.032 & 0.002 & -0.044 \\
\hline 1985 & Japan & -2.599 & -2.747 & -1.458 & 0.194 & 0.170 & 0.027 & 0.063 & 0.012 & -0.035 \\
\hline 1986 & Japan & -2.188 & -2.984 & -1.486 & 0.115 & 0.141 & 0.023 & 0.052 & 0.015 & -0.025 \\
\hline 1987 & Japan & -2.801 & -3.158 & -1.464 & 0.106 & 0.116 & 0.019 & 0.061 & 0.016 & -0.013 \\
\hline 1988 & Japan & -2.680 & -3.212 & -1.506 & 0.174 & 0.092 & 0.016 & 0.045 & 0.018 & -0.004 \\
\hline 1989 & Japan & -3.372 & -3.127 & -1.544 & 0.014 & 0.064 & 0.014 & 0.113 & 0.024 & 0.007 \\
\hline 1990 & Japan & -3.856 & -2.939 & -1.572 & -0.172 & 0.029 & 0.011 & 0.138 & 0.032 & 0.010 \\
\hline 1991 & Japan & -3.421 & -2.713 & -1.603 & -0.289 & -0.011 & 0.008 & 0.148 & 0.039 & 0.019 \\
\hline 1992 & Japan & -2.212 & -2.496 & -1.490 & -0.133 & -0.050 & 0.006 & 0.126 & 0.043 & 0.017 \\
\hline 1993 & Japan & -2.445 & -2.304 & -1.412 & -0.158 & -0.086 & 0.003 & 0.103 & 0.042 & 0.013 \\
\hline 1994 & Japan & -2.636 & -2.131 & -1.332 & -0.200 & -0.115 & 0.001 & 0.090 & 0.036 & 0.008 \\
\hline 1995 & Japan & -2.241 & -1.958 & -1.270 & -0.268 & -0.137 & -0.002 & 0.054 & 0.028 & 0.003 \\
\hline 1996 & Japan & -2.673 & -1.763 & -1.201 & -0.366 & -0.150 & -0.006 & 0.066 & 0.019 & 0.000 \\
\hline 1997 & Japan & -0.584 & -1.536 & -1.140 & -0.471 & -0.155 & -0.010 & -0.048 & 0.009 & 0.001 \\
\hline 1998 & Japan & 1.005 & -1.277 & -1.090 & -0.588 & -0.152 & -0.012 & -0.075 & 0.002 & 0.003 \\
\hline 1999 & Japan & 0.677 & -0.998 & -1.015 & -0.476 & -0.142 & -0.013 & -0.183 & -0.003 & 0.005 \\
\hline 2000 & Japan & 0.015 & -0.714 & -0.872 & -0.355 & -0.127 & -0.012 & -0.141 & -0.004 & 0.008 \\
\hline 2001 & Japan & 0.039 & -0.440 & -0.731 & -0.135 & -0.110 & -0.012 & -0.016 & -0.001 & 0.012 \\
\hline 2002 & Japan & & -0.186 & -0.618 & & -0.091 & -0.011 & & 0.004 & 0.025 \\
\hline 2003 & Japan & & 0.044 & -0.637 & & -0.072 & -0.009 & & 0.011 & 0.053 \\
\hline 2004 & Japan & & 0.247 & -0.634 & & -0.054 & -0.008 & & 0.021 & 0.059 \\
\hline 2005 & Japan & & 0.425 & -0.631 & & -0.035 & -0.007 & & 0.031 & 0.066 \\
\hline$\overline{1972}$ & Netherlands & & $\overline{-0.486}$ & -0.469 & & 0.113 & 0.080 & & 0.368 & 0.176 \\
\hline 1973 & Netherlands & & -0.528 & -0.471 & & 0.115 & 0.079 & & 0.371 & 0.174 \\
\hline 1974 & Netherlands & & -0.570 & -0.480 & & 0.115 & 0.079 & & 0.375 & 0.182 \\
\hline 1975 & Netherlands & & -0.610 & -0.490 & & 0.114 & 0.079 & & 0.376 & 0.153 \\
\hline 1976 & Netherlands & & -0.647 & -0.497 & & 0.111 & 0.080 & & 0.377 & 0.156 \\
\hline 1977 & Netherlands & -0.244 & -0.678 & -0.506 & 0.075 & 0.108 & 0.081 & 0.255 & 0.376 & 0.163 \\
\hline 1978 & Netherlands & -0.199 & -0.705 & -0.522 & 0.072 & 0.103 & 0.082 & -0.132 & 0.373 & 0.169 \\
\hline 1979 & Netherlands & -0.137 & -0.725 & -0.537 & 0.085 & 0.098 & 0.083 & -0.048 & 0.370 & 0.175 \\
\hline 1980 & Netherlands & -0.446 & -0.737 & -0.553 & 0.169 & 0.093 & 0.084 & -0.123 & 0.365 & 0.182 \\
\hline 1981 & Netherlands & -0.271 & -0.739 & -0.563 & 0.133 & 0.088 & 0.085 & 0.219 & 0.360 & 0.181 \\
\hline 1982 & Netherlands & -0.744 & -0.728 & -0.590 & 0.094 & 0.083 & 0.086 & 0.132 & 0.353 & 0.162 \\
\hline 1983 & Netherlands & -1.008 & -0.702 & -0.638 & 0.086 & 0.079 & 0.085 & 0.284 & 0.346 & 0.228 \\
\hline 1984 & Netherlands & -0.842 & -0.662 & -0.616 & 0.083 & 0.076 & 0.083 & 0.239 & 0.336 & 0.293 \\
\hline 1985 & Netherlands & -0.677 & -0.611 & -0.601 & 0.100 & 0.074 & 0.084 & 0.172 & 0.325 & 0.241 \\
\hline 1986 & Netherlands & -0.088 & -0.552 & -0.522 & 0.045 & 0.072 & 0.085 & 0.182 & 0.313 & 0.237 \\
\hline 1987 & Netherlands & 0.705 & -0.494 & -0.454 & 0.011 & 0.071 & 0.085 & 0.208 & 0.301 & 0.231 \\
\hline 1988 & Netherlands & 0.718 & -0.450 & -0.440 & 0.015 & 0.071 & 0.086 & 0.144 & 0.289 & 0.245 \\
\hline 1989 & Netherlands & 0.458 & -0.439 & -0.408 & 0.077 & 0.072 & 0.087 & 0.234 & 0.281 & 0.249 \\
\hline 1990 & Netherlands & 0.709 & -0.476 & -0.378 & 0.075 & 0.073 & 0.087 & 0.221 & 0.276 & 0.251 \\
\hline 1991 & Netherlands & 0.749 & -0.559 & -0.469 & 0.071 & 0.076 & 0.088 & 0.212 & 0.274 & 0.280 \\
\hline 1992 & Netherlands & 0.658 & -0.666 & -0.560 & 0.046 & 0.078 & 0.090 & 0.205 & 0.276 & 0.295 \\
\hline 1993 & Netherlands & -0.055 & -0.771 & -0.654 & 0.056 & 0.081 & 0.092 & 0.256 & 0.281 & 0.303 \\
\hline 1994 & Netherlands & 1.784 & -0.879 & -0.753 & 0.080 & 0.084 & 0.094 & 0.135 & 0.289 & 0.308 \\
\hline 1995 & Netherlands & 1.682 & -1.010 & -0.862 & 0.080 & 0.088 & 0.095 & 0.186 & 0.302 & 0.311 \\
\hline 1996 & Netherlands & 0.767 & -1.170 & -0.984 & 0.097 & 0.094 & 0.096 & 0.329 & 0.319 & 0.311 \\
\hline 1997 & Netherlands & -1.593 & -1.341 & -1.102 & 0.058 & 0.101 & 0.097 & 0.017 & 0.338 & 0.323 \\
\hline 1998 & Netherlands & -2.005 & -1.498 & -1.174 & -0.022 & 0.109 & 0.098 & 0.077 & 0.358 & 0.314 \\
\hline 1999 & Netherlands & -1.746 & -1.627 & -1.283 & 0.093 & 0.116 & 0.099 & 0.280 & 0.376 & 0.303 \\
\hline 2000 & Netherlands & -1.975 & -1.725 & -1.408 & 0.122 & 0.122 & 0.101 & 0.364 & 0.392 & 0.323 \\
\hline 2001 & Netherlands & -1.891 & -1.796 & -1.416 & 0.125 & 0.128 & 0.103 & 0.428 & 0.406 & 0.366 \\
\hline 2002 & Netherlands & & -1.847 & -1.454 & & 0.133 & 0.104 & & 0.418 & 0.385 \\
\hline 2003 & Netherlands & & -1.881 & -1.492 & & 0.137 & 0.106 & & 0.427 & 0.403 \\
\hline 2004 & Netherlands & & -1.904 & -1.535 & & 0.141 & 0.106 & & 0.435 & 0.414 \\
\hline 2005 & Netherlands & & -1.918 & -1.554 & & 0.145 & 0.105 & & 0.442 & 0.428 \\
\hline
\end{tabular}

Note: the table reports the $a_{1 i t}$ coefficients, i.e. the coefficients on the output gap composite variable (see equation 1), using various estimation techniques. 10YRW stands for the 10-years 
rolling window OLS method, WRW for the Gaussian-weighted rolling window OLS method and $A R(1)$ for the $A R(1) M C M C$ method.

Source: OECD Economic Outlook. 


\begin{tabular}{|c|c|c|c|c|c|c|c|c|c|c|}
\hline \multirow[b]{2}{*}{ Year } & \multirow[b]{2}{*}{ Country } & \multicolumn{3}{|c|}{ Procyclicality of public debt } & \multicolumn{3}{|c|}{ Procyclicality of public investment } & \multicolumn{3}{|c|}{ Procyclicality of public consumption } \\
\hline & & 10YRW & WRW & $\mathrm{AR}(1)$ & 10YRW & WRW & $\mathrm{AR}(1)$ & 10YRV & WRW & $\mathrm{AR}(1)$ \\
\hline$\overline{1971}$ & Norway & & 1.080 & 1.346 & & 0.048 & 0.092 & & 0.174 & 0.206 \\
\hline 1972 & Norway & & 1.244 & 1.266 & & 0.067 & 0.091 & & 0.194 & 0.144 \\
\hline 1973 & Norway & & 1.396 & 1.275 & & 0.083 & 0.086 & & 0.211 & 0.147 \\
\hline 1974 & Norway & & 1.531 & 1.193 & & 0.096 & 0.086 & & 0.225 & 0.176 \\
\hline 1975 & Norway & & 1.645 & 1.207 & & 0.106 & 0.086 & & 0.237 & 0.248 \\
\hline 1976 & Norway & 0.564 & 1.738 & 1.056 & -0.019 & 0.113 & 0.081 & 0.089 & 0.245 & 0.220 \\
\hline 1977 & Norway & 1.943 & 1.812 & 1.447 & 0.124 & 0.117 & 0.080 & 0.121 & 0.251 & 0.154 \\
\hline 1978 & Norway & 1.958 & 1.869 & 1.391 & 0.139 & 0.120 & 0.077 & 0.168 & 0.254 & 0.142 \\
\hline 1979 & Norway & 1.943 & 1.913 & 1.094 & 0.124 & 0.120 & 0.073 & 0.219 & 0.255 & 0.103 \\
\hline 1980 & Norway & 1.650 & 1.941 & 1.062 & 0.114 & 0.119 & 0.073 & 0.261 & 0.252 & 0.154 \\
\hline 1981 & Norway & 1.465 & 1.951 & 1.083 & 0.074 & 0.118 & 0.073 & 0.150 & 0.247 & 0.167 \\
\hline 1982 & Norway & 2.584 & 1.937 & 1.129 & 0.098 & 0.115 & 0.074 & 0.037 & 0.238 & 0.158 \\
\hline 1983 & Norway & 1.610 & 1.893 & 1.168 & 0.022 & 0.113 & 0.075 & -0.111 & 0.227 & 0.152 \\
\hline 1984 & Norway & 2.697 & 1.813 & 1.154 & 0.084 & 0.110 & 0.076 & 0.202 & 0.215 & 0.158 \\
\hline 1985 & Norway & 1.498 & 1.700 & 1.153 & 0.057 & 0.108 & 0.078 & 0.177 & 0.202 & 0.154 \\
\hline 1986 & Norway & 1.275 & 1.555 & 1.125 & 0.090 & 0.106 & 0.080 & 0.183 & 0.190 & 0.161 \\
\hline 1987 & Norway & 1.488 & 1.384 & 0.830 & 0.103 & 0.104 & 0.080 & 0.099 & 0.178 & 0.205 \\
\hline 1988 & Norway & 1.475 & 1.189 & 0.698 & 0.109 & 0.102 & 0.080 & 0.094 & 0.164 & 0.193 \\
\hline 1989 & Norway & 1.268 & 0.975 & 0.539 & 0.124 & 0.100 & 0.080 & 0.112 & 0.147 & 0.140 \\
\hline 1990 & Norway & 1.243 & 0.749 & 0.589 & 0.132 & 0.096 & 0.082 & 0.149 & 0.126 & 0.076 \\
\hline 1991 & Norway & 2.147 & 0.524 & 0.450 & 0.163 & 0.092 & 0.081 & 0.193 & 0.102 & 0.058 \\
\hline 1992 & Norway & -0.126 & 0.313 & -0.061 & 0.106 & 0.088 & 0.084 & 0.132 & 0.078 & 0.087 \\
\hline 1993 & Norway & -0.008 & 0.121 & -0.635 & 0.119 & 0.083 & 0.086 & -0.109 & 0.056 & 0.141 \\
\hline 1994 & Norway & -0.585 & -0.053 & -0.830 & 0.099 & 0.080 & 0.084 & -0.046 & 0.040 & 0.176 \\
\hline 1995 & Norway & -0.437 & -0.218 & -1.019 & 0.084 & 0.079 & 0.081 & -0.090 & 0.029 & 0.191 \\
\hline 1996 & Norway & -1.136 & -0.384 & -1.201 & 0.052 & 0.079 & 0.079 & -0.035 & 0.024 & 0.202 \\
\hline 1997 & Norway & -2.887 & -0.558 & -1.374 & 0.165 & 0.081 & 0.077 & 0.078 & 0.024 & 0.211 \\
\hline 1998 & Norway & -6.092 & -0.749 & -1.478 & 0.372 & 0.085 & 0.073 & 0.225 & 0.030 & 0.232 \\
\hline 1999 & Norway & -7.026 & -0.966 & -1.458 & 0.326 & 0.090 & 0.069 & 0.190 & 0.041 & 0.227 \\
\hline 2000 & Norway & -7.278 & -1.215 & -1.384 & 0.384 & 0.096 & 0.067 & 0.249 & 0.058 & 0.244 \\
\hline 2001 & Norway & -5.882 & -1.501 & -1.375 & 0.296 & 0.102 & 0.066 & 0.326 & 0.082 & 0.284 \\
\hline 2002 & Norway & & -1.817 & -1.327 & & 0.107 & 0.065 & & 0.115 & 0.300 \\
\hline 2003 & Norway & & -2.146 & -1.270 & & 0.109 & 0.064 & & 0.156 & 0.315 \\
\hline 2004 & Norway & & -2.456 & -1.254 & & 0.107 & 0.064 & & 0.206 & 0.316 \\
\hline 2005 & Norway & & -2.703 & -1.238 & & 0.098 & 0.064 & & 0.261 & 0.318 \\
\hline 1995 & New Zealand & & -0.303 & -0.252 & & -0.091 & -0.105 & & 0.584 & 0.536 \\
\hline 1996 & New Zealand & & -0.396 & -0.252 & & -0.094 & -0.106 & & 0.550 & 0.530 \\
\hline 1997 & New Zealand & & -0.494 & -0.208 & & -0.096 & -0.106 & & 0.516 & 0.543 \\
\hline 1998 & New Zealand & & -0.592 & -0.172 & & -0.099 & -0.106 & & 0.484 & 0.552 \\
\hline 1999 & New Zealand & & -0.687 & -0.150 & & -0.101 & -0.107 & & 0.454 & 0.503 \\
\hline 2000 & New Zealand & -0.998 & -0.771 & -0.136 & -0.077 & -0.104 & -0.108 & 0.488 & 0.427 & 0.492 \\
\hline 2001 & New Zealand & -0.728 & -0.838 & -0.127 & -0.094 & -0.108 & -0.108 & 0.511 & 0.403 & 0.505 \\
\hline 2002 & New Zealand & & -0.884 & -0.135 & & -0.113 & -0.108 & & 0.384 & 0.509 \\
\hline 2003 & New Zealand & & -0.905 & -0.143 & & -0.118 & -0.108 & & 0.371 & 0.509 \\
\hline 2004 & New Zealand & & -0.898 & -0.145 & & -0.124 & -0.107 & & 0.364 & 0.520 \\
\hline 2005 & New Zealand & & -0.866 & -0.145 & & -0.132 & -0.107 & & 0.365 & 0.520 \\
\hline
\end{tabular}

Note: the table reports the $a_{1 i t}$ coefficients, i.e. the coefficients on the output gap composite variable (see equation 1), using various estimation techniques. 10YRW stands for the 10-years rolling window OLS method, WRW for the Gaussian-weighted rolling window OLS method and $\operatorname{AR}(1)$ for the $A R(1) M C M C$ method.

Source: OECD Economic Outlook. 


\begin{tabular}{|c|c|c|c|c|c|c|c|c|c|c|}
\hline \multirow[b]{2}{*}{ Year } & \multirow[b]{2}{*}{ Country } & \multicolumn{3}{|c|}{ Procyclicality of public debt } & \multicolumn{3}{|c|}{ Procyclicality of public investment } & \multicolumn{3}{|c|}{ Procyclicality of public consumption } \\
\hline & & 10YRW & WRW & $\mathrm{AR}(1)$ & 10YRW & WRW & $\mathrm{AR}(1)$ & 10YRW & WRW & $\mathrm{AR}(1)$ \\
\hline 1971 & Portugal & & -2.163 & -1.696 & & & & & & \\
\hline 1972 & Portugal & & -2.226 & -1.632 & & & & & & \\
\hline 1973 & Portugal & & -2.278 & -1.508 & & & & & & \\
\hline 1974 & Portugal & & -2.310 & -1.616 & & & & & & \\
\hline 1975 & Portugal & & -2.308 & -1.670 & & & & & & \\
\hline 1976 & Portugal & -2.044 & -2.259 & -1.689 & & & & & & \\
\hline 1977 & Portugal & -2.048 & -2.162 & -1.710 & & & & & & \\
\hline 1978 & Portugal & -2.060 & -2.027 & -1.759 & & 0.053 & 0.049 & & -0.003 & 0.275 \\
\hline 1979 & Portugal & -4.116 & -1.873 & -1.809 & & 0.053 & 0.048 & & 0.018 & 0.276 \\
\hline 1980 & Portugal & -5.985 & -1.718 & -1.618 & & 0.052 & 0.049 & & 0.032 & 0.301 \\
\hline 1981 & Portugal & -6.769 & -1.568 & -1.560 & & 0.051 & 0.051 & & 0.042 & 0.260 \\
\hline 1982 & Portugal & -7.653 & -1.421 & -1.502 & & 0.049 & 0.054 & & 0.049 & 0.206 \\
\hline 1983 & Portugal & -2.455 & -1.274 & -1.489 & 0.091 & 0.048 & 0.054 & -0.317 & 0.054 & 0.137 \\
\hline 1984 & Portugal & -1.090 & -1.122 & -1.364 & 0.104 & 0.048 & 0.050 & -0.029 & 0.059 & 0.100 \\
\hline 1985 & Portugal & -0.108 & -0.971 & -1.103 & 0.026 & 0.046 & 0.043 & 0.116 & 0.066 & 0.032 \\
\hline 1986 & Portugal & 0.046 & -0.826 & -0.752 & 0.027 & 0.045 & 0.038 & -0.049 & 0.076 & 0.083 \\
\hline 1987 & Portugal & -0.262 & -0.693 & -1.002 & -0.024 & 0.043 & 0.035 & -0.059 & 0.091 & 0.235 \\
\hline 1988 & Portugal & 0.383 & -0.576 & -0.948 & -0.043 & 0.040 & 0.033 & 0.109 & 0.113 & 0.276 \\
\hline 1989 & Portugal & 0.581 & -0.479 & -0.874 & -0.030 & 0.038 & 0.032 & 0.434 & 0.141 & 0.323 \\
\hline 1990 & Portugal & 0.248 & -0.404 & -0.830 & 0.075 & 0.034 & 0.032 & 0.407 & 0.173 & 0.368 \\
\hline 1991 & Portugal & 0.194 & -0.358 & -0.765 & 0.055 & 0.031 & 0.033 & 0.395 & 0.206 & 0.415 \\
\hline 1992 & Portugal & -0.568 & -0.346 & -1.029 & 0.057 & 0.029 & 0.037 & 0.583 & 0.234 & 0.356 \\
\hline 1993 & Portugal & -0.583 & -0.375 & -1.039 & 0.122 & 0.027 & 0.041 & 0.512 & 0.253 & 0.349 \\
\hline 1994 & Portugal & -0.808 & -0.444 & -1.046 & 0.091 & 0.028 & 0.043 & 0.409 & 0.262 & 0.333 \\
\hline 1995 & Portugal & -0.810 & -0.548 & -1.062 & 0.073 & 0.034 & 0.042 & 0.318 & 0.263 & 0.305 \\
\hline 1996 & Portugal & -0.827 & -0.677 & -1.028 & 0.033 & 0.047 & 0.043 & 0.250 & 0.264 & 0.300 \\
\hline 1997 & Portugal & -1.318 & -0.821 & -0.994 & 0.037 & 0.068 & 0.044 & 0.142 & 0.270 & 0.296 \\
\hline 1998 & Portugal & -1.115 & -0.969 & -0.952 & 0.089 & 0.097 & 0.044 & 0.152 & 0.283 & 0.293 \\
\hline 1999 & Portugal & -1.470 & -1.111 & -0.862 & 0.168 & 0.133 & 0.047 & 0.275 & 0.305 & 0.321 \\
\hline 2000 & Portugal & -1.616 & -1.240 & -0.805 & 0.444 & 0.172 & 0.048 & 0.363 & 0.330 & 0.338 \\
\hline 2001 & Portugal & -1.359 & -1.350 & -0.702 & 0.489 & 0.213 & 0.051 & 0.510 & 0.356 & 0.331 \\
\hline 2002 & Portugal & & -1.440 & -0.641 & & 0.253 & 0.053 & & 0.378 & 0.331 \\
\hline 2003 & Portugal & & -1.512 & -0.562 & & 0.291 & 0.054 & & 0.396 & 0.331 \\
\hline 2004 & Portugal & & -1.571 & -0.531 & & 0.327 & 0.059 & & 0.409 & 0.316 \\
\hline 2005 & Portugal & & -1.624 & -0.549 & & 0.362 & 0.056 & & 0.418 & 0.326 \\
\hline 1971 & Sweden & & -0.856 & -0.936 & & -0.061 & -0.001 & & 0.010 & -0.003 \\
\hline 1972 & Sweden & & -1.016 & -0.929 & & -0.068 & 0.000 & & -0.014 & -0.004 \\
\hline 1973 & Sweden & & -1.181 & -0.913 & & -0.073 & 0.000 & & -0.030 & 0.005 \\
\hline 1974 & Sweden & & -1.348 & -0.936 & & -0.073 & 0.002 & & -0.040 & 0.019 \\
\hline 1975 & Sweden & & -1.513 & -1.021 & & -0.070 & 0.004 & & -0.043 & 0.073 \\
\hline 1976 & Sweden & -1.092 & -1.670 & -1.180 & -0.117 & -0.064 & 0.003 & -0.120 & -0.040 & 0.046 \\
\hline 1977 & Sweden & -0.861 & -1.814 & -1.210 & -0.133 & -0.056 & 0.004 & -0.125 & -0.032 & 0.017 \\
\hline 1978 & Sweden & -0.961 & -1.940 & -1.408 & -0.137 & -0.047 & 0.007 & -0.161 & -0.022 & 0.062 \\
\hline 1979 & Sweden & -1.437 & -2.048 & -1.644 & -0.074 & -0.037 & 0.011 & -0.023 & -0.011 & 0.056 \\
\hline 1980 & Sweden & -1.477 & -2.138 & -1.882 & -0.058 & -0.027 & 0.016 & 0.070 & 0.002 & 0.070 \\
\hline 1981 & Sweden & -2.492 & -2.216 & -2.070 & -0.065 & -0.018 & 0.020 & 0.033 & 0.016 & 0.105 \\
\hline 1982 & Sweden & -2.010 & -2.286 & -2.253 & -0.037 & -0.008 & 0.024 & 0.029 & 0.033 & 0.105 \\
\hline 1983 & Sweden & -2.379 & -2.353 & -2.326 & -0.032 & 0.003 & 0.026 & -0.008 & 0.053 & 0.061 \\
\hline 1984 & Sweden & -2.878 & -2.416 & -2.463 & -0.017 & 0.016 & 0.030 & -0.117 & 0.076 & 0.058 \\
\hline 1985 & Sweden & -2.368 & -2.480 & -2.593 & 0.068 & 0.031 & 0.034 & 0.068 & 0.100 & 0.055 \\
\hline 1986 & Sweden & -2.682 & -2.546 & -2.701 & 0.039 & 0.046 & 0.038 & 0.090 & 0.119 & 0.054 \\
\hline 1987 & Sweden & -3.294 & -2.621 & -2.897 & 0.074 & 0.062 & 0.043 & 0.093 & 0.132 & 0.040 \\
\hline 1988 & Sweden & -3.769 & -2.708 & -2.965 & 0.084 & 0.077 & 0.049 & 0.236 & 0.138 & 0.058 \\
\hline 1989 & Sweden & -2.929 & -2.805 & -3.025 & 0.085 & 0.090 & 0.052 & 0.332 & 0.138 & 0.163 \\
\hline 1990 & Sweden & -2.734 & -2.906 & -3.171 & 0.088 & 0.101 & 0.047 & 0.381 & 0.136 & 0.260 \\
\hline 1991 & Sweden & -2.918 & -3.000 & -3.062 & 0.128 & 0.108 & 0.046 & 0.356 & 0.133 & 0.270 \\
\hline 1992 & Sweden & -3.599 & -3.079 & -2.940 & 0.217 & 0.113 & 0.044 & 0.104 & 0.130 & 0.281 \\
\hline 1993 & Sweden & -3.378 & -3.138 & -2.208 & 0.199 & 0.113 & 0.039 & 0.156 & 0.124 & 0.202 \\
\hline 1994 & Sweden & -3.461 & -3.177 & -2.430 & 0.196 & 0.109 & 0.035 & 0.294 & 0.114 & 0.156 \\
\hline 1995 & Sweden & -3.646 & -3.199 & -2.425 & 0.098 & 0.103 & 0.037 & 0.327 & 0.100 & 0.101 \\
\hline 1996 & Sweden & -2.931 & -3.211 & -2.394 & 0.058 & 0.094 & 0.041 & -0.004 & 0.084 & 0.027 \\
\hline 1997 & Sweden & -3.194 & -3.216 & -2.365 & 0.071 & 0.083 & 0.040 & 0.046 & 0.066 & 0.028 \\
\hline 1998 & Sweden & -2.339 & -3.220 & -2.477 & 0.039 & 0.073 & 0.037 & 0.075 & 0.051 & -0.041 \\
\hline 1999 & Sweden & -3.403 & -3.224 & -2.536 & 0.034 & 0.063 & 0.036 & 0.007 & 0.039 & -0.078 \\
\hline 2000 & Sweden & -3.340 & -3.228 & -2.552 & 0.086 & 0.055 & 0.034 & 0.001 & 0.031 & -0.131 \\
\hline 2001 & Sweden & -3.294 & -3.231 & -2.550 & 0.098 & 0.048 & 0.035 & -0.011 & 0.026 & -0.117 \\
\hline 2002 & Sweden & & -3.235 & -2.551 & & 0.042 & 0.036 & & 0.022 & -0.101 \\
\hline 2003 & Sweden & & -3.238 & -2.552 & & 0.038 & 0.036 & & 0.018 & -0.091 \\
\hline 2004 & Sweden & & -3.241 & -2.553 & & 0.034 & 0.036 & & 0.015 & -0.082 \\
\hline 2005 & Sweden & & -3.241 & -2.551 & & 0.031 & 0.036 & & 0.010 & -0.082 \\
\hline
\end{tabular}

Note: the table reports the $a_{1 i t}$ coefficients, i.e. the coefficients on the output gap composite variable (see equation 1), using various estimation techniques. 10YRW stands for the 10-years 
rolling window OLS method, WRW for the Gaussian-weighted rolling window OLS method and $A R(1)$ for the $A R(1) M C M C$ method.

Source: OECD Economic Outlook. 


\begin{tabular}{|c|c|c|c|c|c|c|c|c|c|c|}
\hline \multirow[b]{2}{*}{ Year } & \multirow[b]{2}{*}{ Country } & \multicolumn{3}{|c|}{ Procyclicality of public debt } & \multicolumn{3}{|c|}{ Procyclicality of public investment } & \multicolumn{3}{|c|}{ Procyclicality of public consumption } \\
\hline & & 10YRW & WRW & $\mathrm{AR}(1)$ & 10YRW & WRW & $\mathrm{AR}(1)$ & 10YRW & WRW & $\mathrm{AR}(1)$ \\
\hline 1964 & United States & & -1.093 & -0.962 & & 0.170 & 0.082 & & 0.273 & 0.183 \\
\hline 1965 & United States & & -1.144 & -0.964 & & 0.156 & 0.082 & & 0.224 & 0.184 \\
\hline 1966 & United States & & -1.187 & -0.981 & & 0.141 & 0.082 & & 0.175 & 0.189 \\
\hline 1967 & United States & & -1.219 & -1.016 & & 0.126 & 0.079 & & 0.129 & 0.151 \\
\hline 1968 & United States & & -1.233 & -1.045 & & 0.112 & 0.076 & & 0.088 & 0.097 \\
\hline 1969 & United States & -1.052 & -1.226 & -1.066 & 0.250 & 0.098 & 0.074 & 0.185 & 0.053 & 0.053 \\
\hline 1970 & United States & -1.043 & -1.196 & -1.056 & 0.216 & 0.084 & 0.073 & 0.037 & 0.026 & 0.018 \\
\hline 1971 & United States & -1.431 & -1.141 & -1.054 & 0.132 & 0.072 & 0.072 & -0.076 & 0.005 & -0.020 \\
\hline 1972 & United States & -1.464 & -1.064 & -1.029 & 0.129 & 0.060 & 0.070 & -0.066 & -0.010 & -0.056 \\
\hline 1973 & United States & -1.426 & -0.970 & -1.002 & 0.126 & 0.049 & 0.069 & -0.040 & -0.019 & -0.092 \\
\hline 1974 & United States & -1.075 & -0.869 & -0.981 & 0.065 & 0.038 & 0.067 & -0.177 & -0.026 & -0.102 \\
\hline 1975 & United States & -0.602 & -0.771 & -0.972 & 0.018 & 0.029 & 0.066 & -0.355 & -0.030 & -0.104 \\
\hline 1976 & United States & -0.378 & -0.679 & -0.900 & 0.060 & 0.024 & 0.066 & -0.412 & -0.035 & -0.086 \\
\hline 1977 & United States & 0.732 & -0.596 & -0.827 & 0.121 & 0.024 & 0.066 & -0.329 & -0.037 & -0.085 \\
\hline 1978 & United States & -0.358 & -0.529 & -0.753 & 0.055 & 0.028 & 0.066 & -0.097 & -0.035 & -0.086 \\
\hline 1979 & United States & -0.215 & -0.479 & -0.728 & 0.035 & 0.034 & 0.066 & -0.083 & -0.030 & -0.080 \\
\hline 1980 & United States & -0.206 & -0.448 & -0.720 & 0.047 & 0.039 & 0.065 & -0.058 & -0.023 & -0.073 \\
\hline 1981 & United States & -0.196 & -0.432 & -0.721 & 0.058 & 0.044 & 0.065 & -0.011 & -0.014 & -0.054 \\
\hline 1982 & United States & -0.297 & -0.428 & -0.763 & 0.054 & 0.049 & 0.064 & 0.010 & -0.005 & -0.020 \\
\hline 1983 & United States & -0.295 & -0.433 & -0.822 & 0.074 & 0.052 & 0.063 & 0.010 & 0.004 & 0.010 \\
\hline 1984 & United States & -0.453 & -0.445 & -0.904 & 0.080 & 0.056 & 0.063 & 0.060 & 0.012 & 0.012 \\
\hline 1985 & United States & -0.677 & -0.466 & -0.973 & 0.064 & 0.059 & 0.063 & 0.162 & 0.020 & 0.012 \\
\hline 1986 & United States & -0.496 & -0.498 & -1.023 & 0.048 & 0.062 & 0.063 & 0.101 & 0.028 & 0.016 \\
\hline 1987 & United States & -0.480 & -0.550 & -1.078 & 0.072 & 0.066 & 0.064 & -0.037 & 0.036 & 0.021 \\
\hline 1988 & United States & -0.663 & -0.631 & -1.139 & 0.068 & 0.070 & 0.064 & 0.083 & 0.042 & 0.024 \\
\hline 1989 & United States & -1.362 & -0.752 & -1.208 & 0.039 & 0.074 & 0.065 & 0.062 & 0.047 & 0.030 \\
\hline 1990 & United States & -2.021 & -0.920 & -1.288 & 0.043 & 0.078 & 0.065 & -0.085 & 0.050 & 0.033 \\
\hline 1991 & United States & -1.979 & -1.139 & -1.366 & 0.084 & 0.082 & 0.066 & -0.063 & 0.051 & 0.034 \\
\hline 1992 & United States & -2.103 & -1.398 & -1.412 & 0.111 & 0.084 & 0.067 & -0.049 & 0.050 & 0.048 \\
\hline 1993 & United States & -2.319 & -1.674 & -1.464 & 0.102 & 0.087 & 0.067 & -0.040 & 0.047 & 0.052 \\
\hline 1994 & United States & -2.528 & -1.934 & -1.516 & 0.101 & 0.088 & 0.067 & -0.061 & 0.044 & 0.046 \\
\hline 1995 & United States & -2.882 & -2.145 & -1.567 & 0.114 & 0.089 & 0.067 & -0.018 & 0.043 & 0.040 \\
\hline 1996 & United States & -3.464 & -2.286 & -1.630 & 0.092 & 0.089 & 0.066 & -0.053 & 0.044 & 0.033 \\
\hline 1997 & United States & -2.228 & -2.352 & -1.694 & 0.089 & 0.087 & 0.066 & 0.159 & 0.046 & 0.025 \\
\hline 1998 & United States & -3.044 & -2.346 & -1.759 & 0.084 & 0.083 & 0.066 & 0.146 & 0.047 & 0.017 \\
\hline 1999 & United States & -2.869 & -2.275 & -1.822 & 0.074 & 0.079 & 0.066 & 0.146 & 0.045 & 0.016 \\
\hline 2000 & United States & -1.790 & -2.148 & -1.911 & 0.054 & 0.074 & 0.066 & 0.079 & 0.040 & 0.005 \\
\hline 2001 & United States & -1.833 & -1.984 & -1.923 & 0.064 & 0.070 & 0.066 & 0.039 & 0.032 & -0.010 \\
\hline 2002 & United States & & -1.807 & -1.958 & & 0.065 & 0.066 & & 0.022 & -0.024 \\
\hline 2003 & United States & & -1.637 & -1.979 & & 0.062 & 0.066 & & 0.009 & -0.030 \\
\hline 2004 & United States & & -1.487 & -1.987 & & 0.059 & 0.066 & & -0.006 & -0.029 \\
\hline 2005 & United States & & -1.363 & -1.986 & & 0.058 & 0.066 & & -0.022 & -0.030 \\
\hline
\end{tabular}

Note: the table reports the $a_{1 i t}$ coefficients, i.e. the coefficients on the output gap composite variable (see equation 1), using various estimation techniques. 10YRW stands for the 10-years rolling window OLS method, WRW for the Gaussian-weighted rolling window OLS method and $\mathrm{AR}(1)$ for the AR(1) MCMC method.

Source: OECD Economic Outlook. 


\section{Appendix 3: Further results for the second stage regressions}

Table 1: The effect of public debt procyclicality on growth, 10-years rolling window method

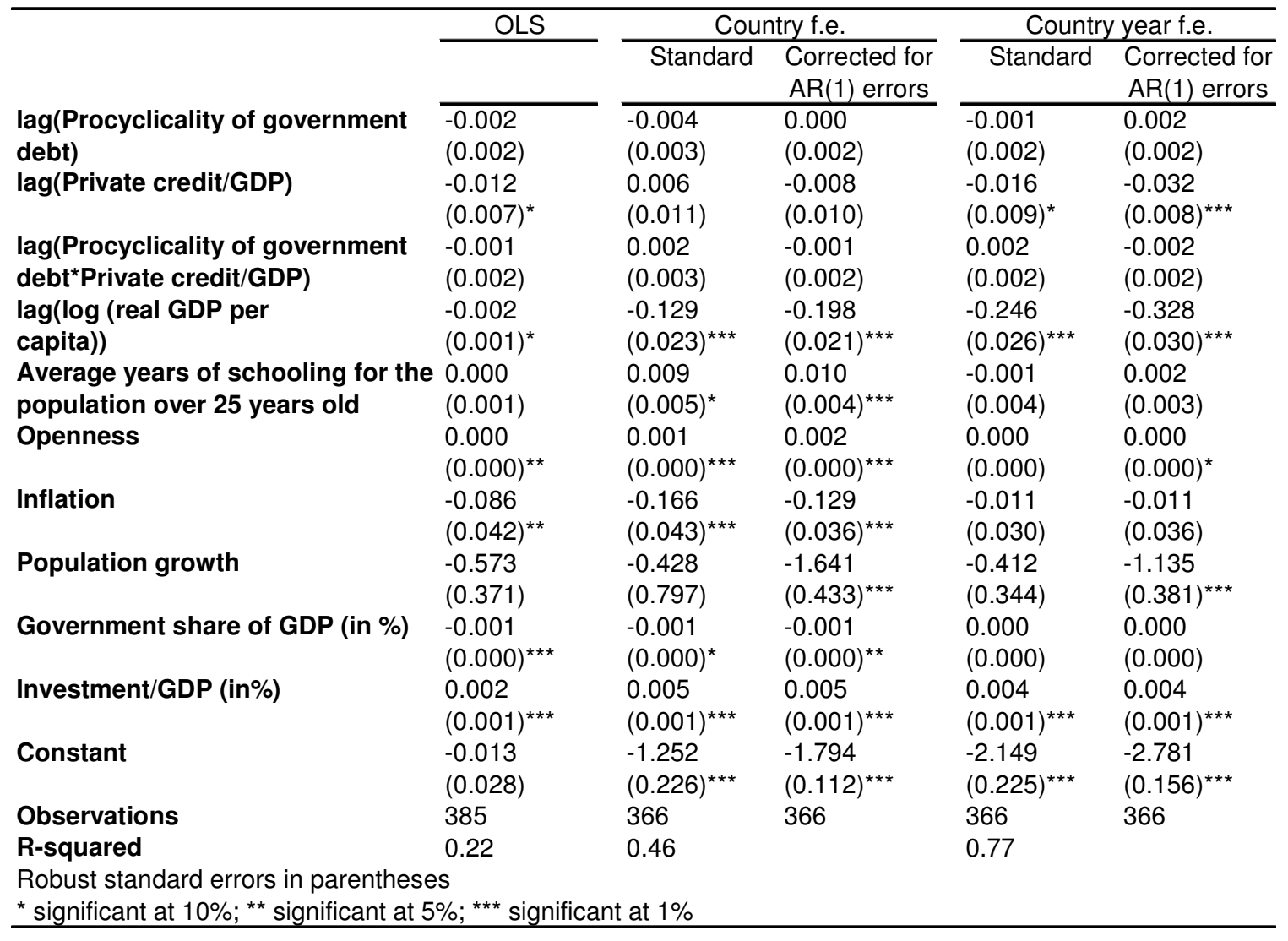

Note: The explained variable is the first difference of the log of real GDP per capita. In columns 3 and 5, we allowed for $A R(1)$ autocorrelation in the error term by using Stata's command xtregar, which implements the method described in Batalgi (2001).

Source: OECD Economic Outlook, Levine dataset, Barro Lee dataset, Penn World Tables 6.1. 
Table 2: The effect of public debt procyclicality on growth, 10-years rolling window method, without controlling for $\operatorname{lag}(\log ($ real GDP per capita) $)$

\begin{tabular}{|c|c|c|c|c|c|}
\hline & \multirow[t]{2}{*}{ OLS } & \multicolumn{2}{|c|}{ Country f.e. } & \multicolumn{2}{|c|}{ Country year f.e. } \\
\hline & & Standard & $\begin{array}{l}\text { Corrected for } \\
\text { AR(1) errors }\end{array}$ & Standard & $\begin{array}{l}\text { Corrected for } \\
A R(1) \text { errors }\end{array}$ \\
\hline $\begin{array}{l}\text { lag(Procyclicality of government } \\
\text { debt) }\end{array}$ & $\begin{array}{l}-0.001 \\
(0.002)\end{array}$ & $\begin{array}{l}-0.008 \\
(0.003)^{* * *}\end{array}$ & $\begin{array}{l}-0.001 \\
(0.002)\end{array}$ & $\begin{array}{l}-0.003 \\
-(0.003)\end{array}$ & -0.000 \\
\hline lag(Private credit/GDP) & $\begin{array}{l}-0.010 \\
(0.007)\end{array}$ & $\begin{array}{l}-0.002 \\
(0.011)\end{array}$ & $\begin{array}{l}-0.026 \\
(0.010)^{\star \star}\end{array}$ & $\begin{array}{l}0.004 \\
(0.011)\end{array}$ & $\begin{array}{l}-0.010 \\
(0.009)\end{array}$ \\
\hline $\begin{array}{l}\text { lag(Procyclicality of government } \\
\text { debt }^{\star} \text { Private credit/GDP) }\end{array}$ & $\begin{array}{l}-0.001 \\
(0.002)\end{array}$ & $\begin{array}{l}0.007 \\
(0.003)^{\star \star}\end{array}$ & $\begin{array}{l}0.001 \\
(0.002)\end{array}$ & $\begin{array}{l}0.005 \\
(0.003)^{*}\end{array}$ & $\begin{array}{l}0.000 \\
(0.002)\end{array}$ \\
\hline Average years of schooling for the & -0.000 & -0.002 & -0.007 & -0.001 & 0.002 \\
\hline population over 25 years old & $(0.001)$ & $(0.004)$ & $(0.003)^{*}$ & $(0.004)$ & $(0.004)$ \\
\hline Openness & $\begin{array}{l}-0.000 \\
(0.000)^{\star *}\end{array}$ & $\begin{array}{l}0.000 \\
(0.000)\end{array}$ & $\begin{array}{l}0.001 \\
(0.000)^{\star * *}\end{array}$ & $\begin{array}{l}-0.001 \\
(0.000)^{*}\end{array}$ & $\begin{array}{l}0.000 \\
(0.000)\end{array}$ \\
\hline Inflation & $\begin{array}{l}-0.093 \\
(0.043)^{\star *}\end{array}$ & $\begin{array}{l}-0.152 \\
(0.045)^{\star \star \star}\end{array}$ & $\begin{array}{l}-0.104 \\
(0.039)^{\star * *}\end{array}$ & $\begin{array}{l}-0.089 \\
(0.042)^{\star *}\end{array}$ & $\begin{array}{l}-0.104 \\
(0.040)^{\star * *}\end{array}$ \\
\hline Population growth & $\begin{array}{l}-0.637 \\
(0.386)^{*}\end{array}$ & $\begin{array}{l}-1.081 \\
(0.838)\end{array}$ & $\begin{array}{l}-2.084 \\
(0.466)^{\star * *}\end{array}$ & $\begin{array}{l}-0.440 \\
(0.530)\end{array}$ & $\begin{array}{l}-1.130 \\
(0.439)^{\star *}\end{array}$ \\
\hline Government share of GDP (in \%) & $\begin{array}{l}-0.001 \\
(0.000)^{\star \star}\end{array}$ & $\begin{array}{l}-0.001 \\
(0.000)^{\star *}\end{array}$ & $\begin{array}{l}-0.001 \\
(0.000)^{\star \star}\end{array}$ & $\begin{array}{l}-0.001 \\
(0.000)^{\star *}\end{array}$ & $\begin{array}{l}-0.001 \\
(0.000)^{\star \star \star}\end{array}$ \\
\hline Investment/GDP (in\%) & $\begin{array}{l}0.002 \\
(0.001)^{\star * *}\end{array}$ & $\begin{array}{l}0.004 \\
(0.001)^{\star * *}\end{array}$ & $\begin{array}{l}0.003 \\
(0.001)^{\star * *}\end{array}$ & $\begin{array}{l}0.001 \\
(0.001)\end{array}$ & $\begin{array}{l}0.002 \\
(0.001)^{\star \star *}\end{array}$ \\
\hline Constant & $\begin{array}{l}0.015 \\
(0.018)\end{array}$ & $\begin{array}{l}-0.031 \\
(0.040)\end{array}$ & $\begin{array}{l}0.012 \\
(0.019)\end{array}$ & $\begin{array}{l}0.013 \\
(0.037)\end{array}$ & $\begin{array}{l}-0.039 \\
(0.026)\end{array}$ \\
\hline $\begin{array}{l}\text { Observations } \\
\text { R-squared }\end{array}$ & $\begin{array}{l}385 \\
0.21\end{array}$ & $\begin{array}{l}366 \\
0.38\end{array}$ & 366 & $\begin{array}{l}366 \\
0.67\end{array}$ & 366 \\
\hline $\begin{array}{l}\text { Robust standard errors in parenthese } \\
{ }^{*} \text { significant at } 10 \% ;{ }^{* *} \text { significant at } 5\end{array}$ & $\begin{array}{l}\text { S } \\
\% ; * * * \\
\text { sigi }\end{array}$ & at $1 \%$ & & & \\
\hline
\end{tabular}

Note: The explained variable is the first difference of the log of real GDP per capita. In columns 3 and 5, we allowed for $A R(1)$ autocorrelation in the error term by using Stata's command xtregar, which implements the method described in Batalgi (2001).

Source: OECD Economic Outlook, Levine dataset, Barro Lee dataset, Penn World Tables 6.1. 
Table 3: The effect of public consumption procyclicality on growth, Gaussian-weighted rolling window OLS method

\begin{tabular}{|c|c|c|c|c|c|}
\hline & \multirow[t]{2}{*}{ OLS } & \multicolumn{2}{|c|}{ Country f.e. } & \multicolumn{2}{|c|}{ Country year f.e. } \\
\hline & & Standard & $\begin{array}{l}\text { Corrected for } \\
\text { AR(1) errors }\end{array}$ & Standard & $\begin{array}{l}\text { Corrected for } \\
A R(1) \text { errors }\end{array}$ \\
\hline \multirow{4}{*}{$\begin{array}{l}\text { lag(Procyclicality of government } \\
\text { consumption) } \\
\text { lag(Private credit/GDP) }\end{array}$} & -0.042 & -0.060 & 0.000 & -0.046 & -0.022 \\
\hline & $(0.019)^{* *}$ & $(0.023)^{* * *}$ & $(0.037)$ & $(0.020)^{\star *}$ & $(0.033)$ \\
\hline & -0.011 & -0.023 & -0.006 & -0.024 & -0.028 \\
\hline & $(0.004)^{\star \star}$ & $(0.007)^{\star * *}$ & $(0.011)$ & $(0.007)^{\star * *}$ & $(0.011)^{* * *}$ \\
\hline \multirow{4}{*}{$\begin{array}{l}\text { lag(Procyclicality of government } \\
\text { consumptionPrivate credit/GDP) } \\
\text { lag(log (real GDP per } \\
\text { capita)) }\end{array}$} & 0.043 & 0.050 & -0.009 & 0.040 & 0.015 \\
\hline & $(0.022)^{\star *}$ & $(0.024)^{\star *}$ & $(0.042)$ & $(0.021)^{*}$ & $(0.038)$ \\
\hline & -0.001 & -0.064 & -0.149 & -0.111 & -0.249 \\
\hline & $(0.001)^{*}$ & $(0.018)^{* * *}$ & $(0.021)^{\star \star \star}$ & $(0.022)^{\star * *}$ & $(0.030)^{\star * *}$ \\
\hline \multirow{4}{*}{$\begin{array}{l}\text { Average years of schooling for the } \\
\text { population over } 25 \text { years old } \\
\text { Openness }\end{array}$} & 0.000 & 0.006 & 0.019 & 0.004 & 0.010 \\
\hline & $(0.001)$ & $(0.004)$ & $(0.004)^{\star * \star}$ & $(0.003)$ & $(0.004)^{* * *}$ \\
\hline & 0.000 & 0.001 & 0.001 & 0.000 & 0.000 \\
\hline & $(0.000)^{*}$ & $(0.000)^{* * *}$ & $(0.000)^{\star * *}$ & $(0.000)^{\star *}$ & $(0.000)$ \\
\hline \multirow[t]{2}{*}{ Inflation } & -0.087 & -0.153 & -0.138 & -0.049 & -0.070 \\
\hline & $(0.029)^{* * *}$ & $(0.036)^{* * *}$ & $(0.030)^{\star * *}$ & $(0.031)$ & $(0.029)^{\star *}$ \\
\hline \multirow[t]{2}{*}{ Population growth } & -0.304 & -1.038 & -0.678 & -0.647 & -0.292 \\
\hline & $(0.295)$ & $(0.468)^{\star *}$ & $(0.398)^{*}$ & $(0.349)^{*}$ & $(0.362)$ \\
\hline \multirow[t]{2}{*}{ Government share of GDP (in \%) } & 0.000 & -0.001 & -0.001 & 0.000 & -0.001 \\
\hline & $(0.000)$ & $(0.000)^{* *}$ & $(0.000)^{* *}$ & $(0.000)^{*}$ & $(0.000)^{*}$ \\
\hline \multirow[t]{2}{*}{ Investment/GDP (in\%) } & 0.002 & 0.003 & 0.004 & 0.002 & 0.003 \\
\hline & $(0.000)^{* * *}$ & $(0.000)^{* * *}$ & $(0.000)^{\star * *}$ & $(0.000)^{* * *}$ & $(0.001)^{* * *}$ \\
\hline \multirow[t]{2}{*}{ Constant } & -0.015 & -0.566 & -1.443 & -0.903 & -2.024 \\
\hline & $(0.017)$ & $(0.174)^{\star * *}$ & $(0.109)^{\star * *}$ & $(0.186)^{* * *}$ & $(0.126)^{* * *}$ \\
\hline Observations & 453 & 434 & 434 & 434 & \\
\hline R-squared & 0.14 & 0.33 & & 0.57 & \\
\hline \multicolumn{6}{|c|}{ Robust standard errors in parentheses } \\
\hline
\end{tabular}

Note: The explained variable is the first difference of the log of real GDP per capita. In columns 3 and 5, we allowed for $A R(1)$ autocorrelation in the error term by using Stata's command xtregar, which implements the method described in Batalgi (2001).

Source: OECD Economic Outlook, Levine dataset, Barro Lee dataset, Penn World Tables 6.1. 
Table 4: The effect of public investment procyclicality on growth, Gaussian-weighted rolling window OLS method

\begin{tabular}{|c|c|c|c|c|c|}
\hline & \multirow[t]{2}{*}{ OLS } & \multicolumn{2}{|c|}{ Country f.e. } & \multicolumn{2}{|c|}{ Country year f.e. } \\
\hline & & Standard & $\begin{array}{l}\text { Corrected for } \\
\text { AR(1) errors }\end{array}$ & Standard & $\begin{array}{l}\text { Corrected for } \\
A R(1) \text { errors }\end{array}$ \\
\hline \multirow{4}{*}{$\begin{array}{l}\text { lag(Procyclicality of government } \\
\text { investment) } \\
\text { lag(Private credit/GDP) }\end{array}$} & -0.095 & -0.055 & 0.050 & -0.064 & -0.058 \\
\hline & $(0.036)^{* * *}$ & $(0.039)$ & $(0.086)$ & $(0.033)^{*}$ & $(0.141)$ \\
\hline & -0.007 & -0.012 & 0.002 & -0.016 & -0.015 \\
\hline & $(0.004)^{*}$ & $(0.007)^{\star}$ & $(0.012)$ & $(0.007)^{\star *}$ & $(0.016)$ \\
\hline \multirow{4}{*}{$\begin{array}{l}\text { lag(Procyclicality of government } \\
\text { investment*Private credit/GDP) } \\
\text { lag(log (real GDP per } \\
\text { capita)) }\end{array}$} & 0.098 & 0.034 & -0.102 & 0.029 & -0.046 \\
\hline & $(0.034)^{\star \star *}$ & $(0.032)$ & $(0.081)$ & $(0.027)$ & $(0.125)$ \\
\hline & -0.002 & -0.074 & -0.237 & -0.128 & -0.638 \\
\hline & $(0.001)$ & $(0.018)^{\star \star \star}$ & $(0.024)^{\star * \star}$ & $(0.025)^{\star * *}$ & $(0.041)^{\star * *}$ \\
\hline \multirow{4}{*}{$\begin{array}{l}\text { Average years of schooling for the } \\
\text { population over } 25 \text { years old } \\
\text { Openness }\end{array}$} & 0.001 & 0.005 & 0.026 & 0.002 & 0.005 \\
\hline & $(0.001)$ & $(0.004)$ & $(0.004)^{\star * \star}$ & $(0.003)$ & $(0.006)$ \\
\hline & 0.000 & 0.001 & 0.002 & 0.000 & 0.000 \\
\hline & $(0.000)$ & $(0.000)^{\star * *}$ & $(0.000)^{\star * *}$ & $(0.000)^{\star *}$ & $(0.000)$ \\
\hline \multirow[t]{2}{*}{ Inflation } & -0.032 & -0.096 & -0.123 & -0.034 & -0.018 \\
\hline & $(0.020)$ & $(0.023)^{\star * *}$ & $(0.030)^{\star * *}$ & $(0.027)$ & $(0.026)$ \\
\hline \multirow[t]{2}{*}{ Population growth } & -0.902 & -1.303 & -0.367 & -0.685 & 0.201 \\
\hline & $(0.321)^{\star \star \star}$ & $(0.585)^{\star *}$ & $(0.449)$ & $(0.456)$ & $(0.399)$ \\
\hline \multirow[t]{2}{*}{ Government share of GDP (in \%) } & 0.000 & 0.000 & -0.001 & 0.000 & 0.000 \\
\hline & $(0.000)$ & $(0.000)$ & $(0.000)^{*}$ & $(0.000)$ & $(0.000)$ \\
\hline \multirow[t]{2}{*}{ Investment/GDP (in\%) } & 0.001 & 0.003 & 0.005 & 0.002 & 0.006 \\
\hline & $(0.000)^{* * *}$ & $(0.001)^{\star * *}$ & $(0.001)^{* * *}$ & $(0.000)^{* * *}$ & $(0.001)^{\star * *}$ \\
\hline \multirow[t]{2}{*}{ Constant } & -0.008 & -0.705 & -2.334 & -1.123 & -5.136 \\
\hline & $(0.019)$ & $(0.176)^{\star * *}$ & $(0.095)^{* * *}$ & $(0.216)^{\star * *}$ & $(0.063)^{* * *}$ \\
\hline Observations & 453 & 434 & 434 & 434 & 434 \\
\hline R-squared & 0.11 & 0.3 & & 0.55 & \\
\hline \multicolumn{6}{|c|}{ Robust standard errors in parentheses } \\
\hline
\end{tabular}

Note: The explained variable is the first difference of the log of real GDP per capita. In columns 3 and 5, we allowed for $A R(1)$ autocorrelation in the error term by using Stata's command xtregar, which implements the method described in Batalgi (2001).

Source: OECD Economic Outlook, Levine dataset, Barro Lee dataset, Penn World Tables 6.1. 